Supporting Information

\title{
Usnic Acid Derivatives with Cytotoxic and Antifungal Activities from the Lichen
}

\section{Usnea longissima}

Xuelong Yu, ${ }^{\dagger, * \#}$ Qiang Guo, ${ }^{\dagger,+\#}$ Guozhu Su, ${ }^{\dagger+}$ Ailin Yang, ${ }^{\dagger,+}$ Zhongdong Hu, ${ }^{*, \dagger}$ Changhai Qu, ${ }^{\dagger}$ Zhe Wan, ${ }^{\S}$ Ruoyu Li, ${ }^{\S}$ Pengfei Tu, ${ }^{*, \dagger}$ and Xingyun Chai ${ }^{*}, \dagger$

$\dagger$ Modern Research Center for Traditional Chinese Medicine, Beijing University of Chinese

Medicine, Beijing 100029, People's Republic of China

† School of Chinese Materia Medica, Beijing University of Chinese Medicine, Beijing 100102,

People's Republic of China

${ }^{\S}$ Department of Dermatology and Venereology, Peking University First Hospital, Research Center

for Medical Mycology, Peking University, Beijing 100034, People’s Republic of China

${ }^{\#}$ These authors contribute to the paper equally.

*To whom correspondence should be addressed:

Chai X., tel/fax: 86106428 6350, e-mail: xingyunchai@yeah.net;

Tu P., tel/fax: 86108280 2750, e-mail: pengfeitu@vip.163.com;

Hu Z., tel/fax: 86106428 6180, e-mail: huzhongdong@126.com 


\section{The List of Content}

\begin{tabular}{|c|c|}
\hline No & Content \\
\hline 1 & In vitro antifungal assay \\
\hline 2 & In vitro antibacterial assay \\
\hline S1 & HRESIMS spectrum of compound $\mathbf{1}$ \\
\hline S2 & ${ }^{1}$ H NMR spectrum of compound 1 (Measured in DMSO- $d_{6}$ ) \\
\hline S3 & ${ }^{13} \mathrm{C}$ NMR spectrum of compound $\mathbf{1}$ (Measured in DMSO- $d_{6}$ ) \\
\hline S4 & gHSQC spectrum of compound 1 (Measured in DMSO- $d_{6}$ ) \\
\hline S5 & gHMBC spectrum of compound 1 (Measured in DMSO- $d_{6}$ ) \\
\hline S6 & NOESY spectrum of compound 1 (Measured in DMSO- $d_{6}$ ) \\
\hline S7 & $\mathrm{CD}$ spectrum of compound $\mathbf{1}$ (Measured in $\mathrm{CH}_{3} \mathrm{OH}$ ) \\
\hline S8 & HRESIMS spectrum of compound $\mathbf{2}$ \\
\hline S9 & ${ }^{1} \mathrm{H}$ NMR spectrum of compound 2 (Measured in $\mathrm{CD}_{3} \mathrm{OD}$ ) \\
\hline S10 & ${ }^{13} \mathrm{C}$ NMR spectrum of compound 2 (Measured in $\mathrm{CD}_{3} \mathrm{OD}$ ) \\
\hline S11 & gHSQC spectrum of compound 2 (Measured in $\mathrm{CD}_{3} \mathrm{OD}$ ) \\
\hline S12 & gHMBC spectrum of compound 2 (Measured in $\mathrm{CD}_{3} \mathrm{OD}$ ) \\
\hline S13 & NOESY spectrum of compound $\mathbf{2}$ (Measured in $\mathrm{CD}_{3} \mathrm{OD}$ ) \\
\hline S14 & $\mathrm{CD}$ spectrum of compound 2 (Measured in $\mathrm{CH}_{3} \mathrm{OH}$ ) \\
\hline S15 & ${ }^{1} \mathrm{H}$ NMR spectrum of compound 2 (Measured in DMSO- $d_{6}$ ) \\
\hline S16 & HRESIMS spectrum of compound $\mathbf{3}$ \\
\hline S17 & ${ }^{1} \mathrm{H}$ NMR spectrum of compound 3 (Measured in $\mathrm{CD}_{3} \mathrm{OD}$ ) \\
\hline S18 & ${ }^{13} \mathrm{C}$ NMR spectrum of compound 3 (Measured in $\mathrm{CD}_{3} \mathrm{OD}$ ) \\
\hline S19 & gHSQC spectrum of compound 3 (Measured in $\mathrm{CD}_{3} \mathrm{OD}$ ) \\
\hline S20 & gHMBC spectrum of compound $\mathbf{3}$ (Measured in $\mathrm{CD}_{3} \mathrm{OD}$ ) \\
\hline S21 & NOESY spectrum of compound $\mathbf{3}$ (Measured in $\mathrm{CD}_{3} \mathrm{OD}$ ) \\
\hline S22 & $\mathrm{CD}$ spectrum of compound 3 (Measured in $\mathrm{CH}_{3} \mathrm{OH}$ ) \\
\hline $\mathbf{S 2 3}$ & HRESIMS spectrum of compound $\mathbf{4}$ \\
\hline S24 & ${ }^{1} \mathrm{H}$ NMR spectrum of compound 4 (Measured in $\mathrm{CD}_{3} \mathrm{OD}$ ) \\
\hline S25 & ${ }^{13} \mathrm{C}$ NMR spectrum of compound 4 (Measured in $\mathrm{CD}_{3} \mathrm{OD}$ ) \\
\hline S26 & gHSQC spectrum of compound 4 (Measured in $\left.\mathrm{CD}_{3} \mathrm{OD}\right)$ \\
\hline S27 & gHMBC spectrum of compound 4 (Measured in $\mathrm{CD}_{3} \mathrm{OD}$ ) \\
\hline S28 & NOESY spectrum of compound 4 (Measured in $\mathrm{CD}_{3} \mathrm{OD}$ ) \\
\hline S29 & ${ }^{1} \mathrm{H}$ NMR spectrum of compound 4 (Measured in $\mathrm{CDCl}_{3}$ ) \\
\hline S30 & ${ }^{13} \mathrm{C}$ NMR spectrum of compound 4 (Measured in $\mathrm{CDCl}_{3}$ ) \\
\hline S31 & gHSQC spectrum of compound 4 (Measured in $\mathrm{CDCl}_{3}$ ) \\
\hline S32 & gHMBC spectrum of compound 4 (Measured in $\mathrm{CDCl}_{3}$ ) \\
\hline S33 & $\mathrm{CD}$ spectrum of compound 4 (Measured in $\mathrm{CH}_{3} \mathrm{OH}$ ) \\
\hline S34 & HRESIMS spectrum of compound $\mathbf{5}$ \\
\hline S35 & ${ }^{1} \mathrm{H}$ NMR spectrum of compound $\mathbf{5}$ (Measured in $\mathrm{CD}_{3} \mathrm{OD}$ ) \\
\hline S36 & ${ }^{13} \mathrm{C}$ NMR spectrum of compound 5 (Measured in $\mathrm{CD}_{3} \mathrm{OD}$ ) \\
\hline S37 & gHSQC spectrum of compound $\mathbf{5}$ (Measured in $\mathrm{CD}_{3} \mathrm{OD}$ ) \\
\hline S38 & gHMBC spectrum of compound $\mathbf{5}$ (Measured in $\mathrm{CD}_{3} \mathrm{OD}$ ) \\
\hline S39 & NOESY spectrum of compound $\mathbf{5}$ (Measured in $\mathrm{CD}_{3} \mathrm{OD}$ ) \\
\hline
\end{tabular}




\begin{tabular}{|c|c|}
\hline $\mathbf{S 4 0}$ & CD spectrum of compound 5 (Measured in $\mathrm{CH}_{3} \mathrm{OH}$ ) \\
\hline S41 & HRESIMS spectrum of compound 6 \\
\hline S42 & ${ }^{1} \mathrm{H}$ NMR spectrum of compound 6 (Measured in $\mathrm{CD}_{3} \mathrm{OD}$ ) \\
\hline $\mathbf{S 4 3}$ & ${ }^{13} \mathrm{C}$ NMR spectrum of compound $\mathbf{6}$ (Measured in $\mathrm{CD}_{3} \mathrm{OD}$ ) \\
\hline S44 & gHSQC spectrum of compound $\mathbf{6}$ (Measured in $\mathrm{CD}_{3} \mathrm{OD}$ ) \\
\hline $\mathbf{S 4 5}$ & gHMBC spectrum of compound $\mathbf{6}$ (Measured in $\mathrm{CD}_{3} \mathrm{OD}$ ) \\
\hline S46 & NOESY spectrum of compound $\mathbf{6}$ (Measured in $\mathrm{CD}_{3} \mathrm{OD}$ ) \\
\hline S47 & CD spectrum of compound 6 (Measured in $\mathrm{CH}_{3} \mathrm{OH}$ ) \\
\hline S48 & HRESIMS spectrum of compound 7 \\
\hline S49 & ${ }^{1} \mathrm{H}$ NMR spectrum of compound 7 (Measured in $\mathrm{CD}_{3} \mathrm{OD}$ ) \\
\hline S50 & ${ }^{13} \mathrm{C}$ NMR spectrum of compound 7 (Measured in $\mathrm{CD}_{3} \mathrm{OD}$ ) \\
\hline S51 & gHSQC spectrum of compound 7 (Measured in $\mathrm{CD}_{3} \mathrm{OD}$ ) \\
\hline S52 & gHMBC spectrum of compound 7 (Measured in $\mathrm{CD}_{3} \mathrm{OD}$ ) \\
\hline S53 & NOESY spectrum of compound 7 (Measured in $\mathrm{CD}_{3} \mathrm{OD}$ ) \\
\hline S54 & CD spectrum of compound 7 (Measured in $\mathrm{CH}_{3} \mathrm{OH}$ ) \\
\hline $\mathbf{S 5 5}$ & HRESIMS spectrum of compound $\mathbf{8}$ \\
\hline S56 & ${ }^{1} \mathrm{H}$ NMR spectrum of compound $\mathbf{8}$ (Measured in $\mathrm{CD}_{3} \mathrm{OD}$ ) \\
\hline S57 & ${ }^{13} \mathrm{C}$ NMR spectrum of compound 8 (Measured in $\mathrm{CD}_{3} \mathrm{OD}$ ) \\
\hline S58 & gHSQC spectrum of compound $\mathbf{8}$ (Measured in $\mathrm{CD}_{3} \mathrm{OD}$ ) \\
\hline S59 & gHMBC spectrum of compound 8 (Measured in $\mathrm{CD}_{3} \mathrm{OD}$ ) \\
\hline S60 & NOESY spectrum of compound $\mathbf{8}$ (Measured in $\mathrm{CD}_{3} \mathrm{OD}$ ) \\
\hline S61 & $\mathrm{CD}$ spectrum of compound $\mathbf{8}$ (Measured in $\left.\mathrm{CH}_{3} \mathrm{OH}\right)$ \\
\hline S62 & $\begin{array}{l}\text { LC-MS chromatograms in positive (A) and negative (B) modes of } 2 \text { in the } \mathrm{MeOH} \text { extract of } \\
\text { Usnea longissima }\end{array}$ \\
\hline S63 & LC-MS chromatograms in positive $(\mathbf{A})$ and negative $(\mathbf{B})$ modes of 2 \\
\hline S64 & $\begin{array}{l}\text { Extract ion chromatograms and } \mathrm{MS}^{2} \text { data in negative modes of } \mathbf{2} \text { in } \mathrm{MeOH} \text { extract of Usnea } \\
\text { longissima and those of purified } \mathbf{2} \text {. }\end{array}$ \\
\hline
\end{tabular}




\section{In vitro antifungal assay}

The samples were stocked in DMSO at $6400 \mu \mathrm{g} / \mathrm{mL}$. The sample solution was further diluted with RPMI-1640 medium prior to each test. Each sample was then diluted to a 1:2 ratio, divided into 10 tubes, and pipetted into 96-well plates (100 $\mu \mathrm{L} /$ well). To prepare the inocula for bioassays, the fungi strains were individually cultured at $30{ }^{\circ} \mathrm{C}$ until the spores grew well in the potato dextrose agar. Sporangiospore suspensions were counted with a hemocytometer and suspended in RPMI 1640 medium to specific their concentrations: $1-3 \times 10^{3}$ colony forming units $(\mathrm{CFU}) / \mathrm{mL}$ for Trichophyton, $0.4-5 \times 10^{4} \mathrm{CFU} / \mathrm{mL}$ for Aspergillus, and $0.5-2.5 \times 10^{3} \mathrm{CFU} / \mathrm{mL}$ for Candida (twice the final concentration), followed by co-incubation with samples at $35^{\circ} \mathrm{C}$. For the conventional micro-dilution procedure, the values of $\mathrm{MIC}_{50}$, which is defined as the lowest concentration required to support $50 \%$ growth inhibition compared with growth in the control wells, were determined visually with a concave mirror for each test sample after incubation for $4 \mathrm{~d}, 2 \mathrm{~d}$, and 24 h, respectively. The tested results are listed in the following table.

Table. Susceptibilities of tested drugs against isolates ${ }^{\mathrm{a}}$

\begin{tabular}{llllllllll}
\hline & $\mathbf{1}$ & $\mathbf{2}$ & $\mathbf{3}$ & $\mathbf{4}$ & $\mathbf{5}$ & $\mathbf{6}$ & $\mathbf{7}$ & $\mathbf{8}$ & $\mathbf{9}$ \\
\hline C. albican & $>16$ & $>16$ & $>16$ & $>16$ & $>16$ & $>16$ & $>16$ & $>16$ & $>16$ \\
C. parapsilosis & $>16$ & $>16$ & $>16$ & $>16$ & $>16$ & $>16$ & $>16$ & $>16$ & $>16$ \\
T. mentagrophytes & $>16$ & $>16$ & $>16$ & $>16$ & $>16$ & $>16$ & $\geq 32$ & $\geq 32$ & $\geq 16$ \\
T. rubrum & $\geq 16$ & $\geq 16$ & $\geq 16$ & $\geq 16$ & $>16$ & $>16$ & 16 & 16 & $\geq 16$ \\
A. fumigatus & $>16$ & $>16$ & $>16$ & $>16$ & $>16$ & $>16$ & $>16$ & $>16$ & $>16$ \\
A. flavus & $>16$ & $>16$ & $>16$ & $>16$ & $>16$ & $>16$ & $>16$ & $>16$ & $>16$ \\
\hline
\end{tabular}

\footnotetext{
${ }^{\mathrm{a}}$ Values are in micrograms per milliliter.
} 


\section{In vitro antibacterial assay}

The MICs of the antibacterial agents for all three clinical isolates were determined by broth microdilution method according to CLSI guidelines. Wells of 96-well microtiter plates were inoculated with $100 \mu \mathrm{L}$ of cation-adjusted Mueller-Hinton broth containing serial-diluted antimicrobials. The concentration ranges for samples $\mathbf{1}, \mathbf{2}, \mathbf{5}, \mathbf{7}, \mathbf{8}$, and $\mathbf{9}$ were as follows: 0.03 $\mu \mathrm{g} / \mathrm{mL}$ to $64 \mu \mathrm{g} / \mathrm{mL}$ for Escherichia coli, Bacillus subtilis, and Mycobacterium smegmatis. The microtiter plates were incubated at $37^{\circ} \mathrm{C}$. The MIC was defined as the lowest concentration of an antimicrobial agent that prevented turbidity. All MIC determinations were performed in triplicate. 
Data File: D:IDatas I于学龙|新建文件夹IYXL-01.Icd

\begin{tabular}{|c|c|c|c|c|c|c|c|c|c|c|c|c|}
\hline Elmt & Val. & Min & Max & Elmt & Val. & Min & Max & Elmt & Val. & Min & Max & Use Adduct \\
\hline $\mathrm{H}$ & 1 & 0 & 50 & 0 & 2 & 0 & 20 & $S$ & 2 & 0 & 0 & $\mathrm{H}$ \\
\hline C & 4 & 0 & 50 & $\mathrm{~F}$ & 1 & 0 & 0 & $\mathrm{Cl}$ & 1 & 0 & 0 & $\mathrm{Na}$ \\
\hline $\mathrm{N}$ & 3 & 0 & 4 & P & 3 & 0 & 5 & & & & & $\mathrm{NH} 4$ \\
\hline $\begin{array}{r}\text { Error N } \\
\mathrm{MS}\end{array}$ & $\begin{array}{r}\operatorname{argin} \\
\mathrm{HC} \\
\mathrm{ax} \text { Iso } \\
\text { Iso } \mathrm{F}\end{array}$ & $\begin{array}{l}\text { pm): } \\
\text { atio: } \\
\text { pes: } \\
(\%) \text { : }\end{array}$ & $\begin{array}{l}20 \\
\text { unlimited } \\
\text { all } \\
75.00\end{array}$ & & & $\begin{array}{r}\text { D } \\
\text { Ap } \\
\text { Isotc } \\
\text { MSn L }\end{array}$ & $\begin{array}{l}\text { BE Ra } \\
\text { ply N F } \\
\text { ope RI } \\
\text { ogic M }\end{array}$ & $\begin{array}{l}\text { e: }-2 . \\
\text { e: yes } \\
\text { ): } 1.0 \\
\text { e: AN }\end{array}$ & 1000 & & & $\begin{array}{c}\text { Electron lons: both } \\
\text { Use MSn Info: yes } \\
\text { Isotope Res: } 10000 \\
\text { Max Results: } 700\end{array}$ \\
\hline
\end{tabular}

Event\#: $1 \mathrm{MS}(\mathrm{E}+)$ Ret. Time : 76.128 Scan\# : 8118
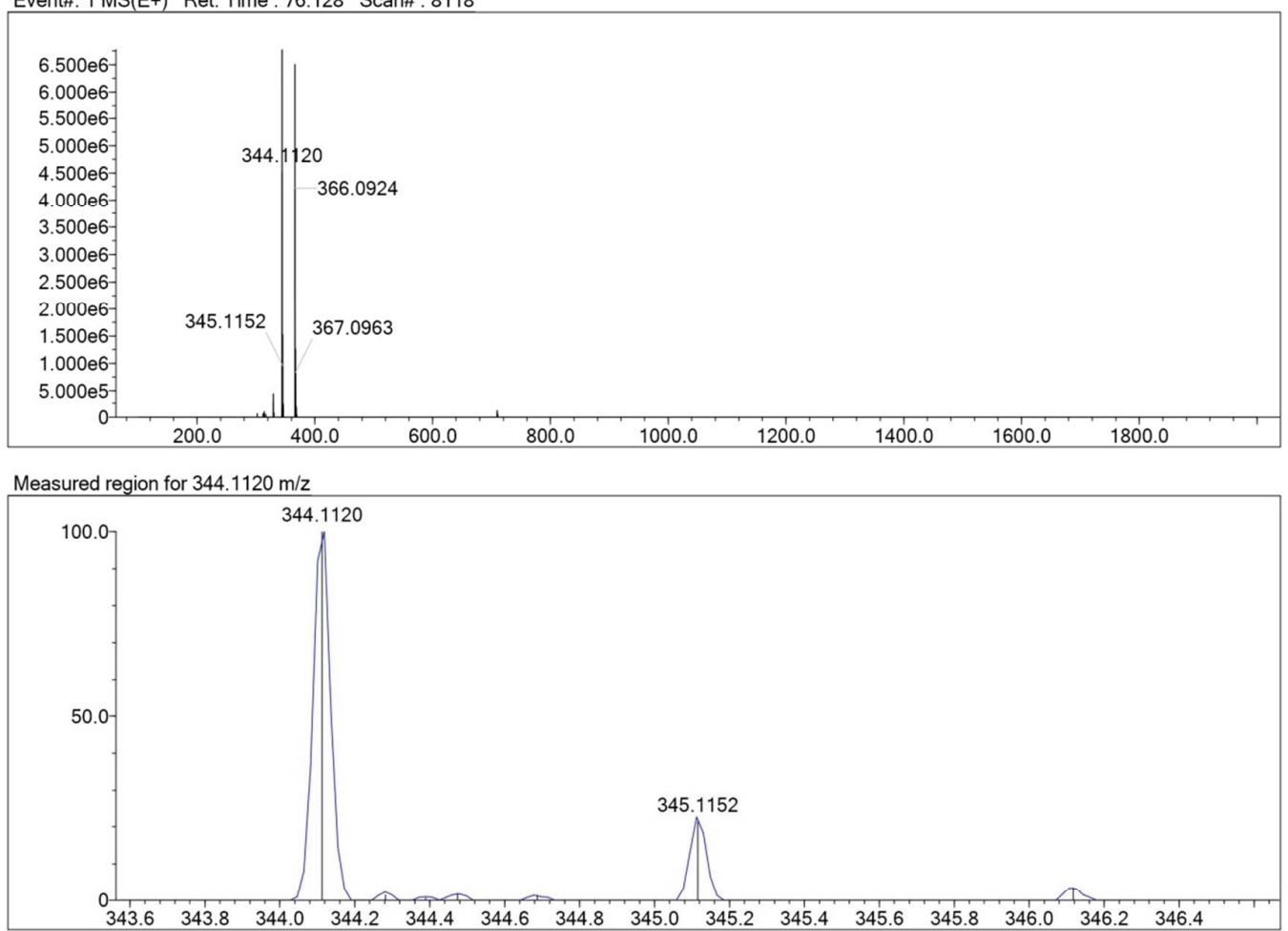

$\mathrm{C} 18 \mathrm{H} 17 \mathrm{~N} \mathrm{O6}[\mathrm{M}+\mathrm{H}]+$ : Predicted region for $344.1129 \mathrm{~m} / \mathrm{z}$

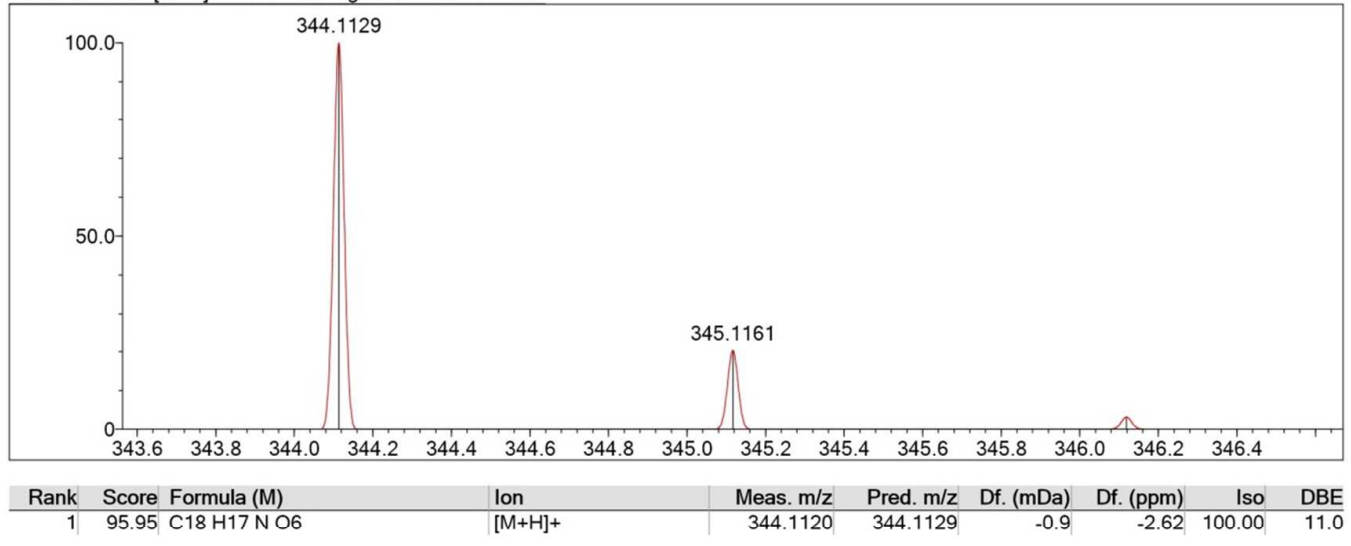

S1 HRESIMS spectrum of compound 1 


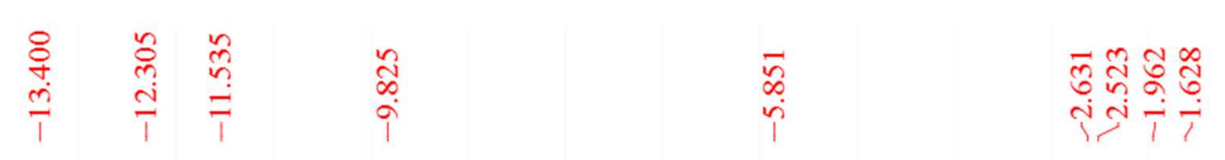<smiles>CC(=O)c1c(O)c(C)c(O)c2c1OC1=CC(=O)/C(=C(/C)N)C(=O)[C@@]1(C)C2=O</smiles>

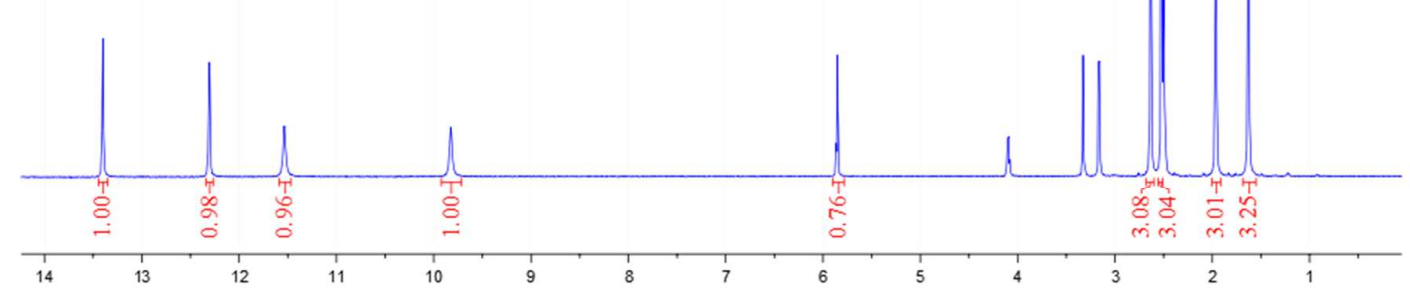

S2 ${ }^{1} \mathrm{H}$ NMR spectrum of compound 1 (Measured in DMSO- $d_{6}$ )
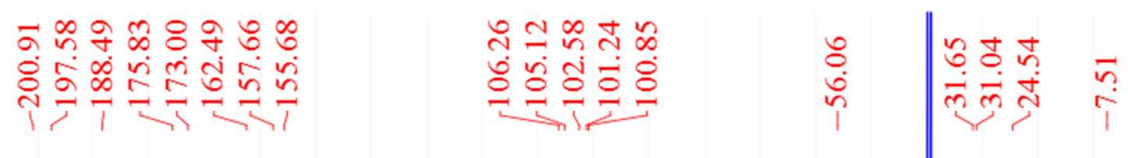<smiles>CC(=O)c1c(O)c(C)c(O)c2c1OC1=CC(=O)/C(=C(/C)N)C(=O)[C@@]1(C)C2=O</smiles>
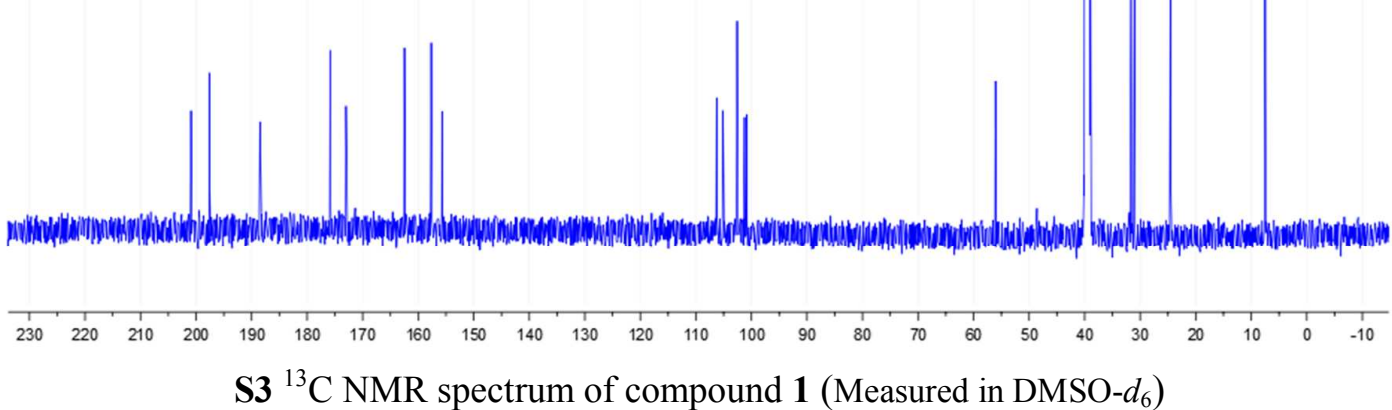


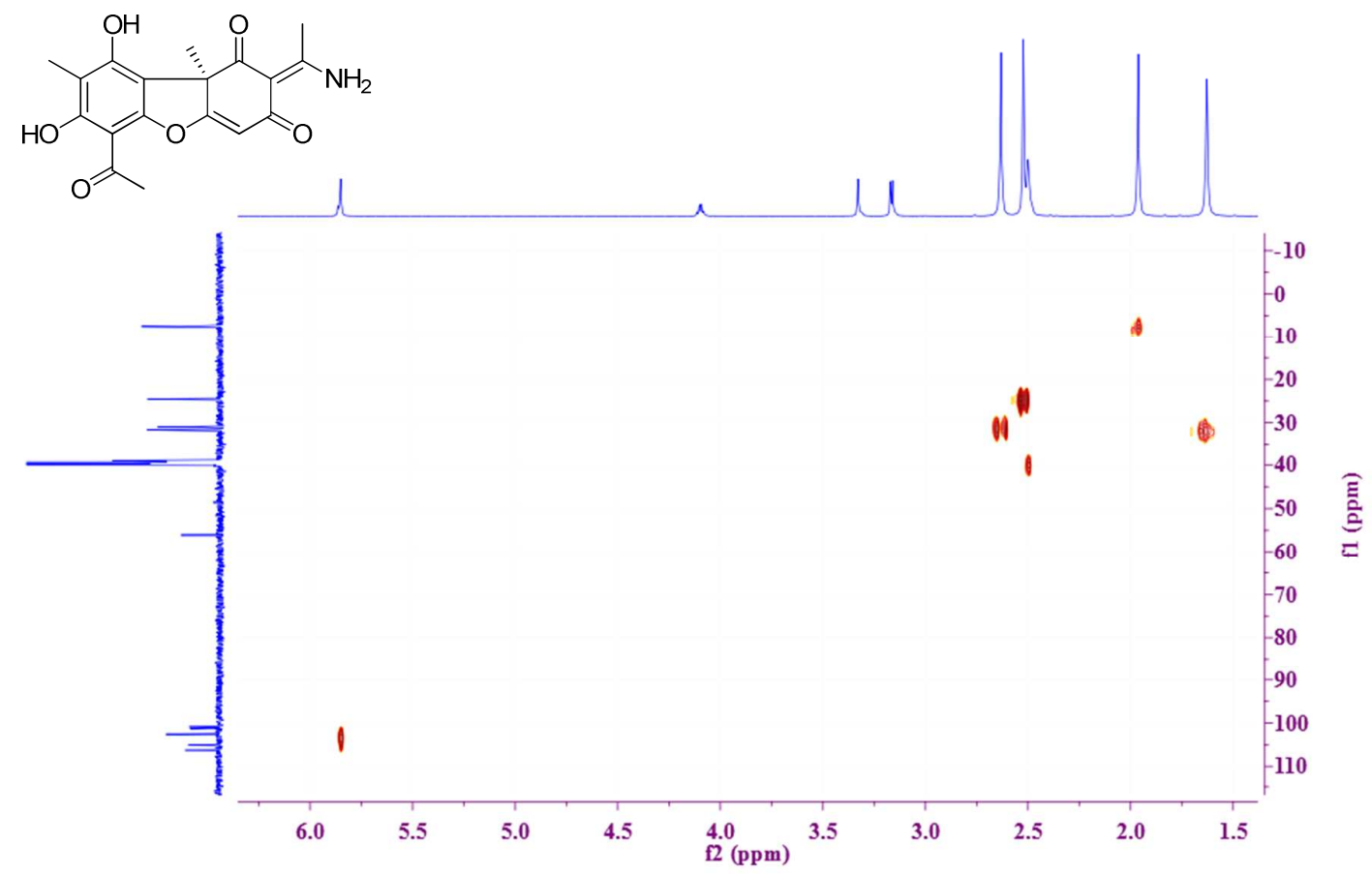

S4 gHSQC spectrum of compound 1 (Measured in DMSO- $d_{6}$ )
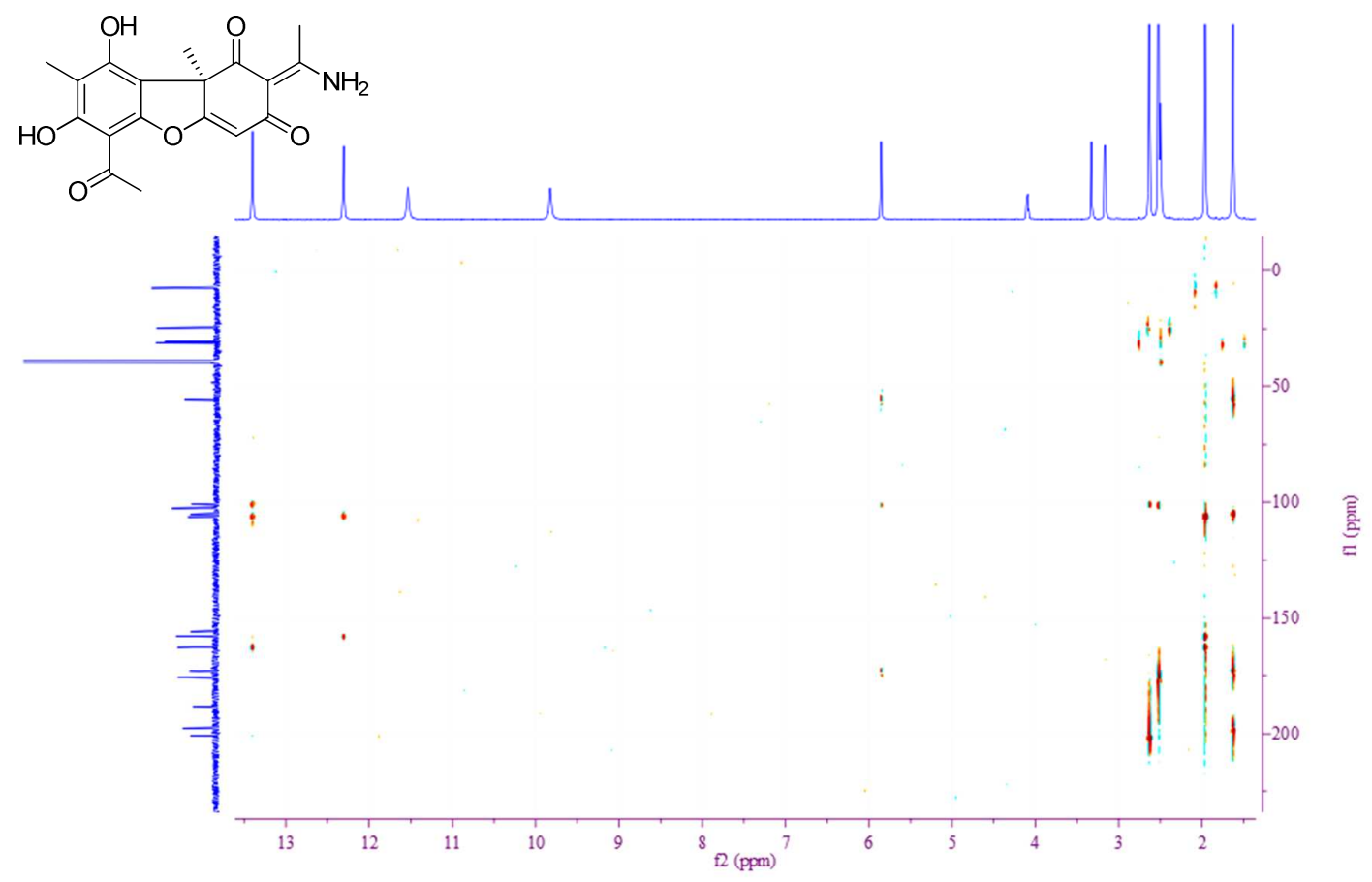

S5 gHMBC spectrum of compound 1 (Measured in DMSO- $d_{6}$ ) 


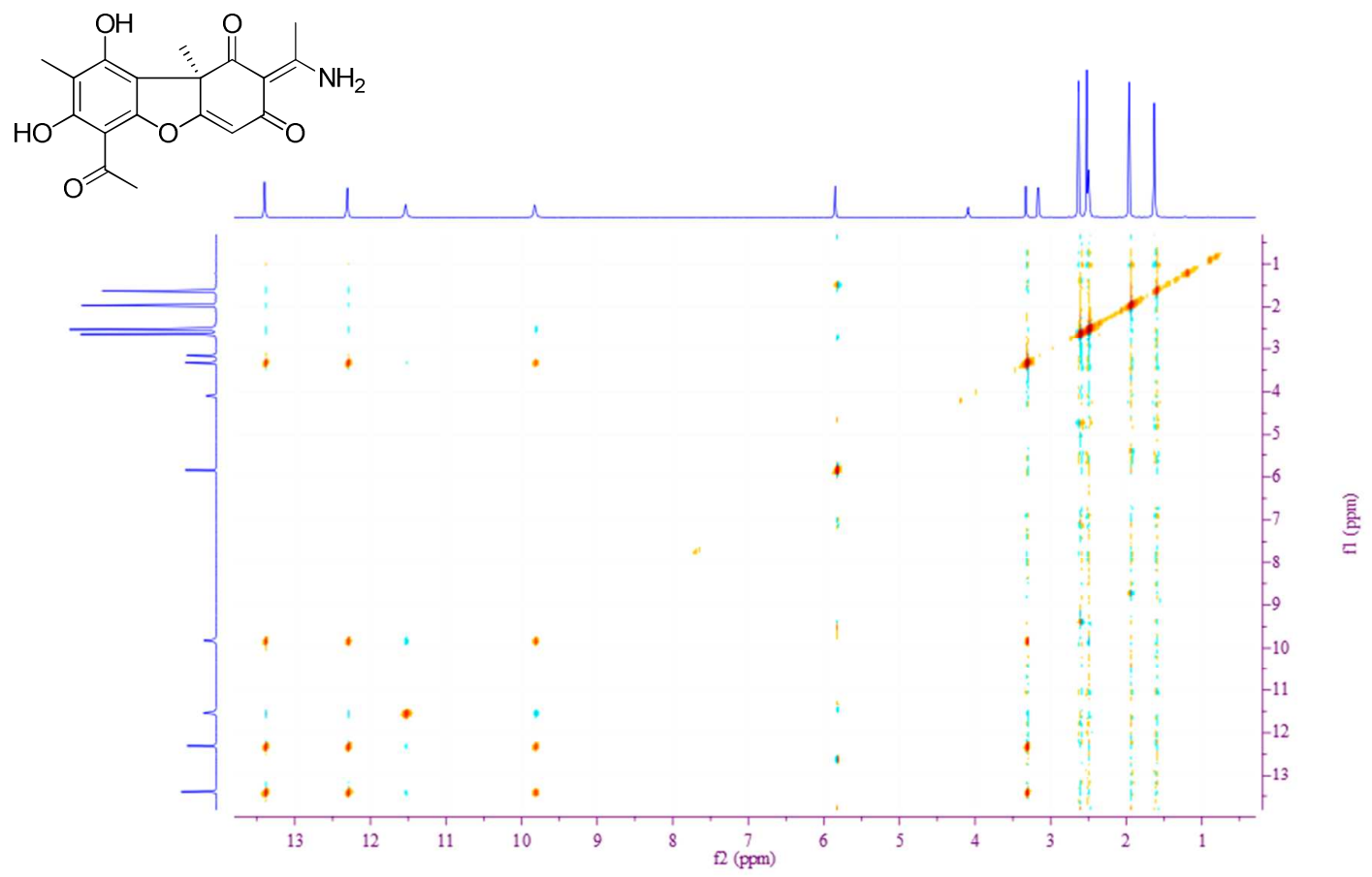

S6 NOESY spectrum of compound 1 (Measured in DMSO- $d_{6}$ )

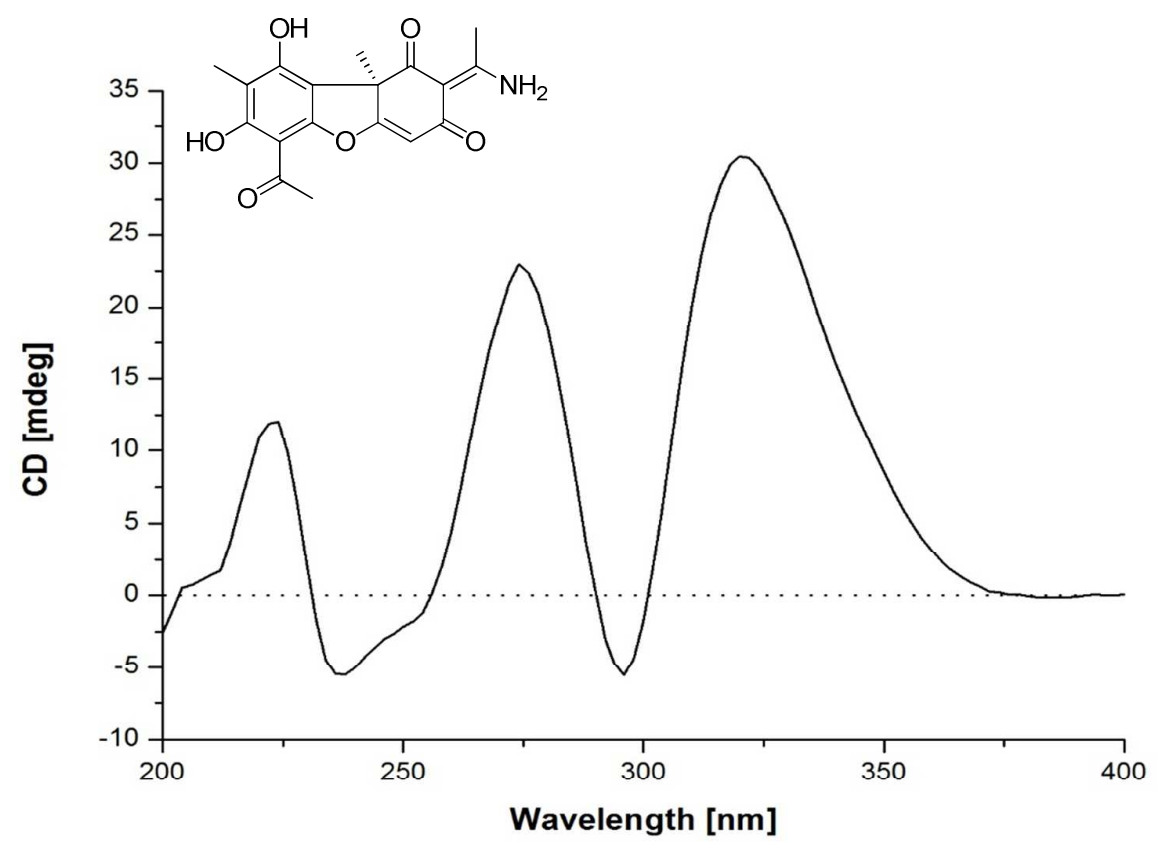

S7 CD spectrum of compound 1 (Measured in $\mathrm{CH}_{3} \mathrm{OH}$ ) 
Data File: D:IDatas I于学龙1新建文件夹IYXL-02.Icd

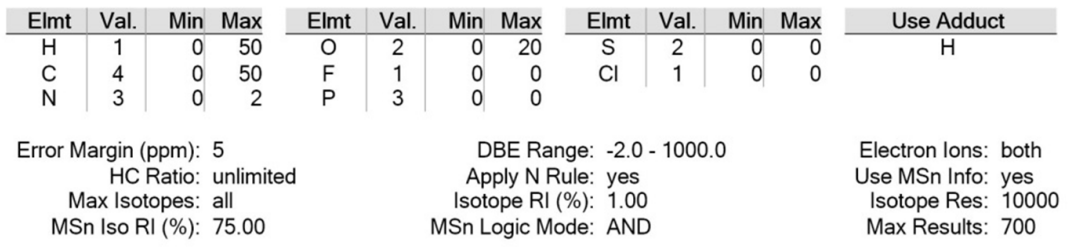

Event\#: 1 MS(E+) Ret. Time : 76.208 -> 76.447 - $75.833<->77.015$ Scan\# : 8068 -> 8090 - $8033<$ <> 8142

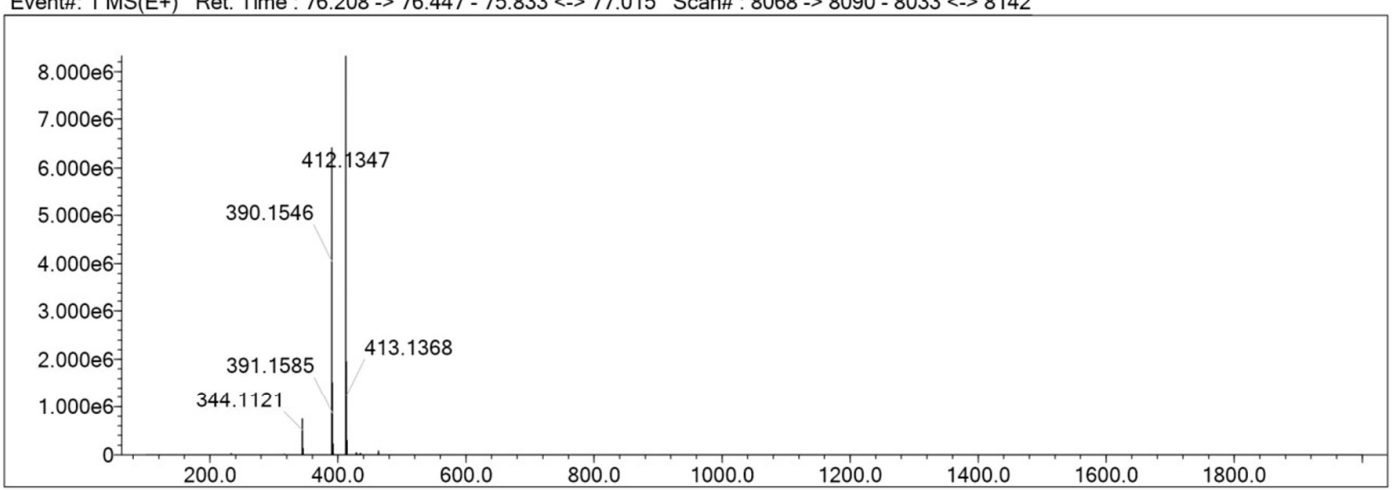

Measured region for $390.1546 \mathrm{~m} / \mathrm{z}$

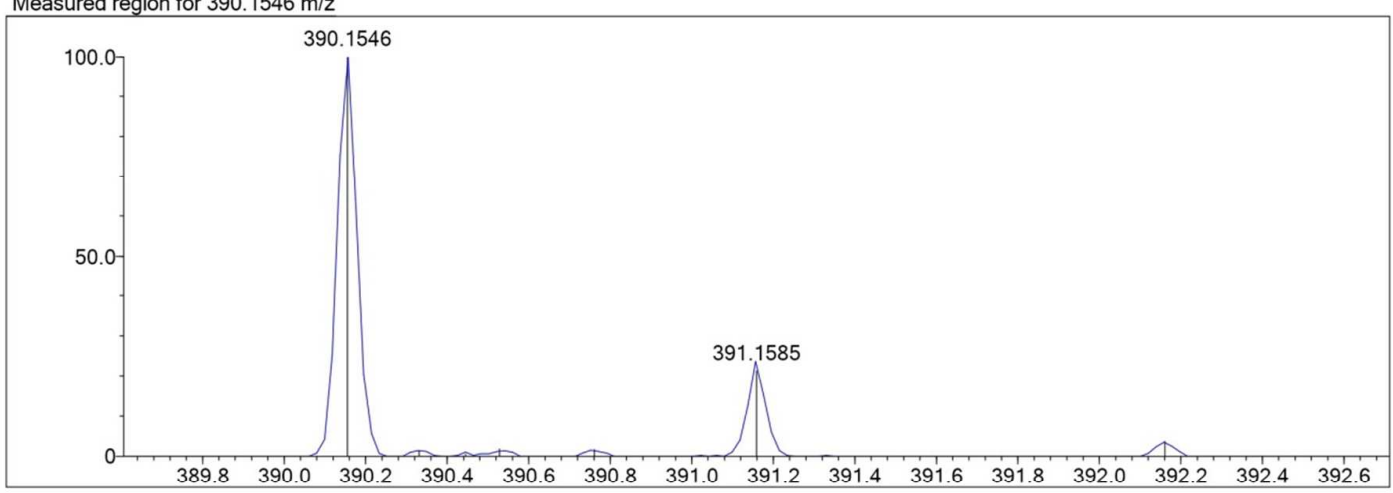

$\mathrm{C} 20 \mathrm{H} 23 \mathrm{~N} \mathrm{O} 7[\mathrm{M}+\mathrm{H}]+$ : Predicted region for $390.1547 \mathrm{~m} / \mathrm{z}$

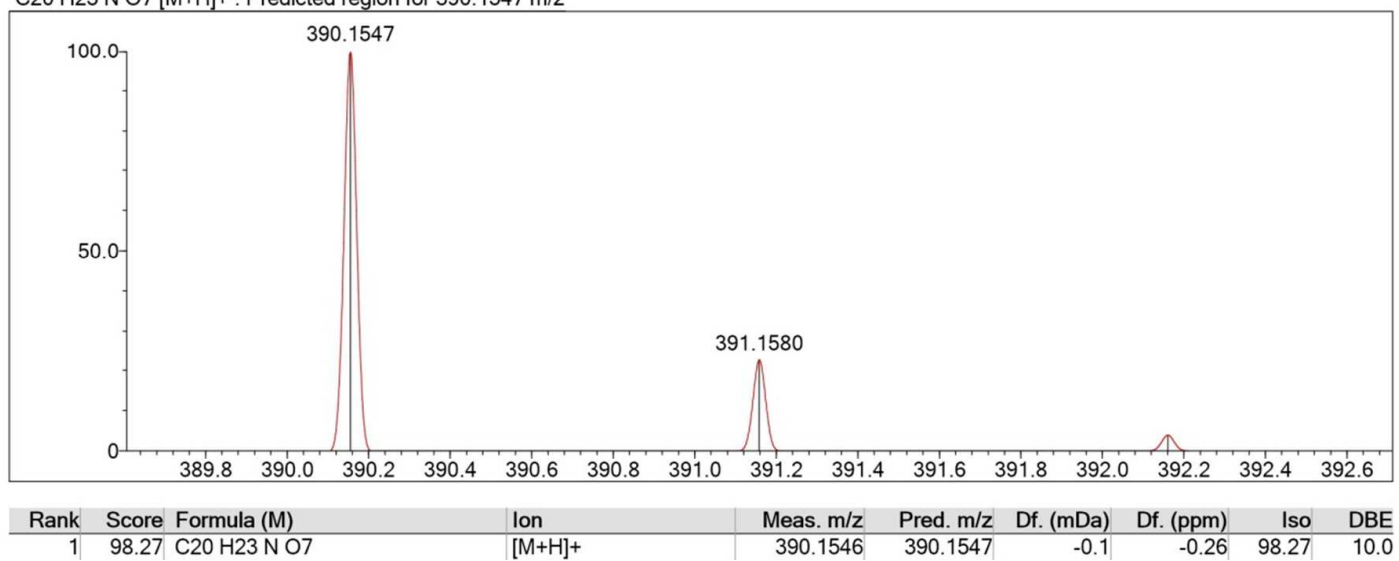

\section{S8 HRESIMS spectrum of compound 2}


<smiles>CCO[C@]12CC(=O)C(=C(C)N)C(=O)[C@@]1(C)c1c(O)c(C)c(O)c(C(C)=O)c1O2</smiles>
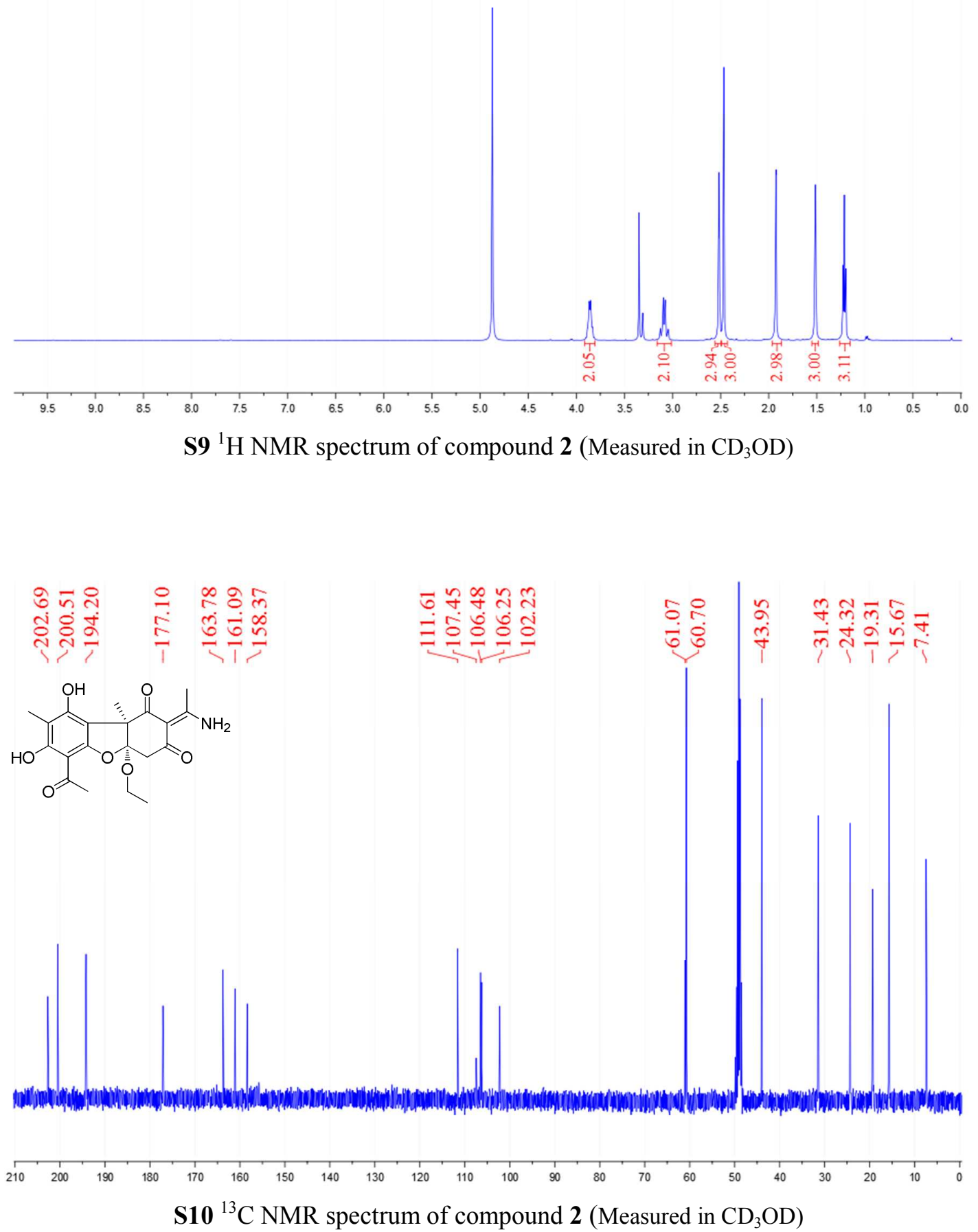


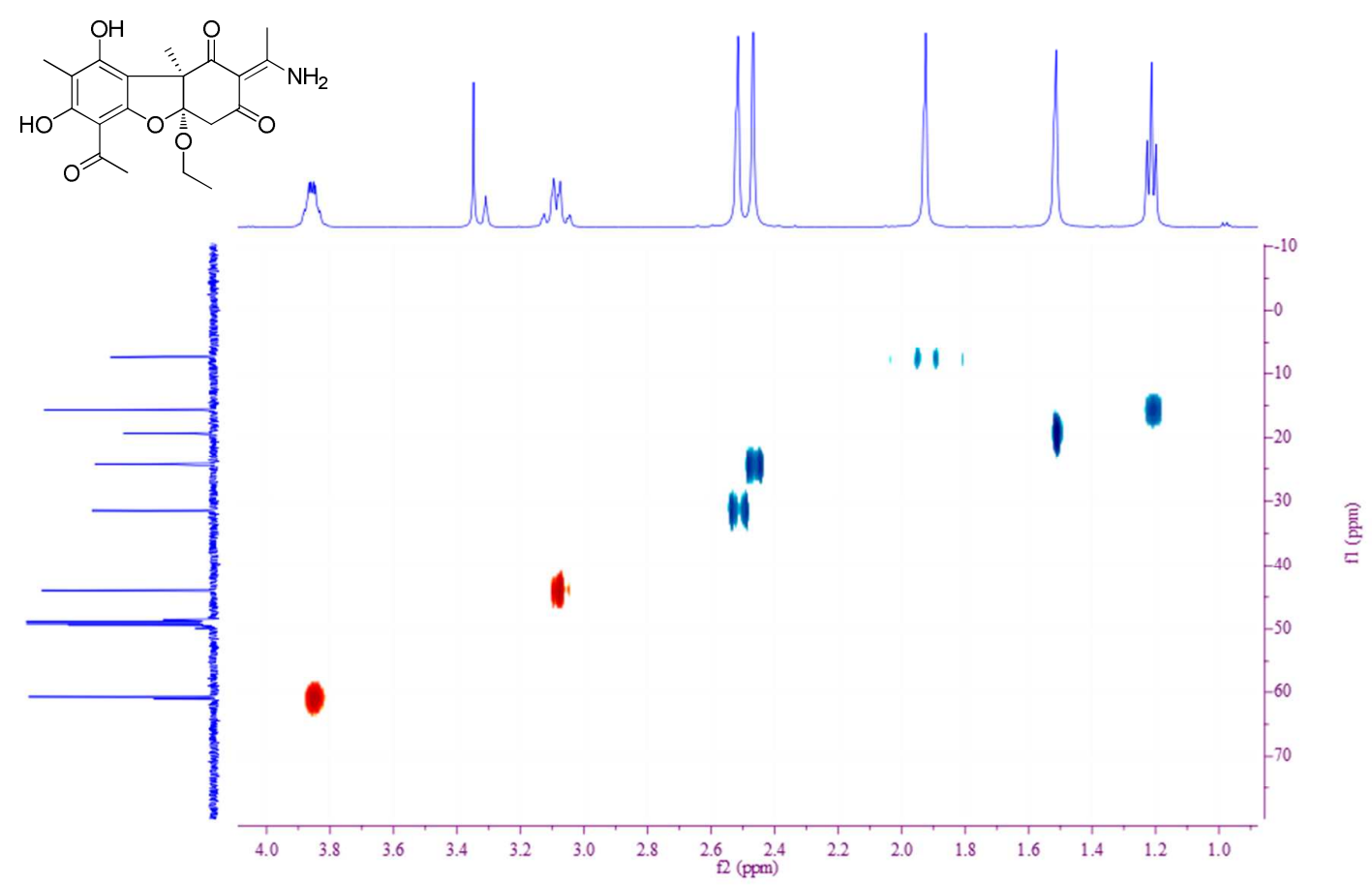

S11 gHSQC spectrum of compound 2 (Measured in $\mathrm{CD}_{3} \mathrm{OD}$ )<smiles>CCOc1c(OC2CC(=O)C(=C(C)N)C(=O)C2=O)c(O)c(C)c(O)c1C(C)=O</smiles>
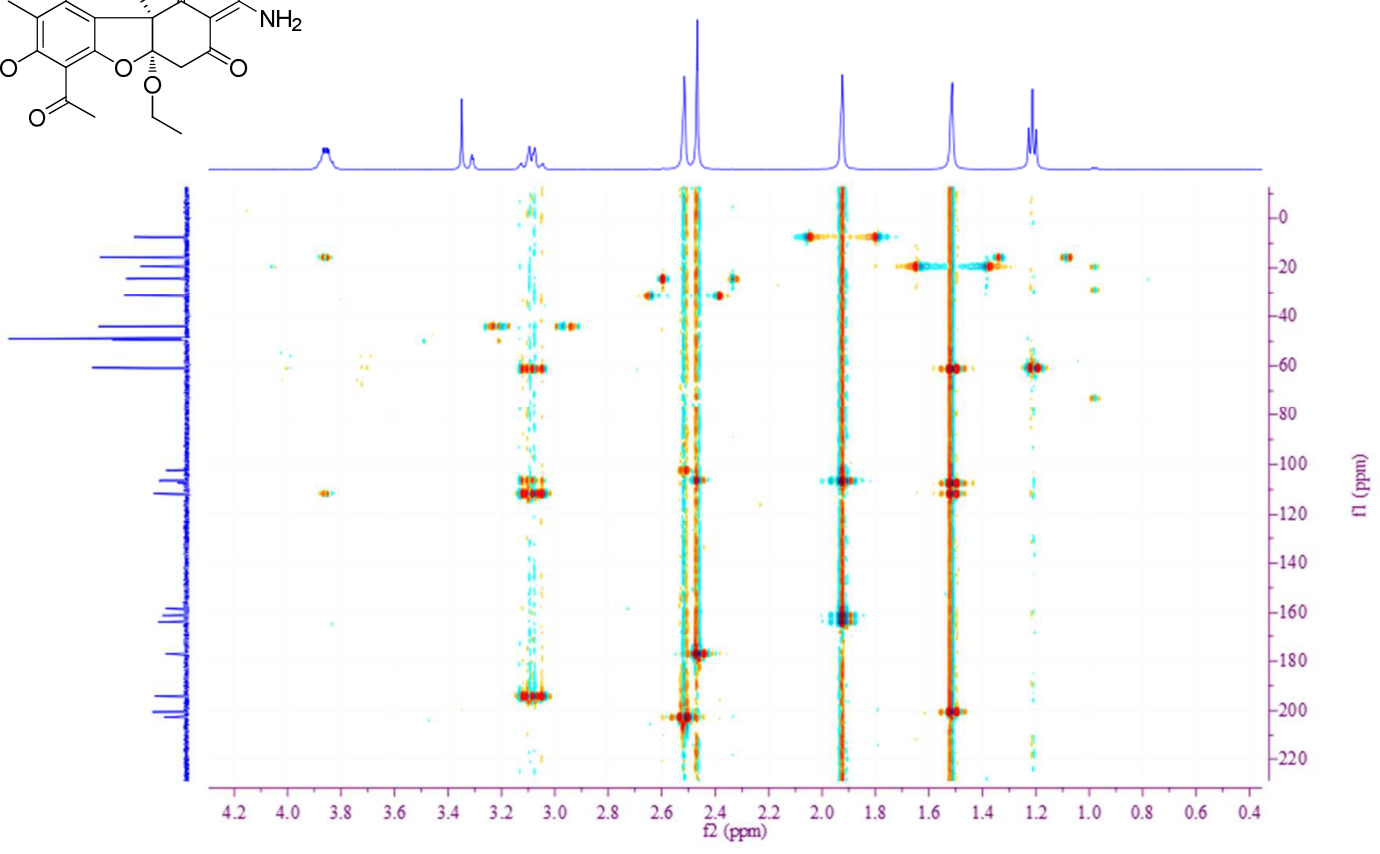

S12 gHMBC spectrum of compound 2 (Measured in $\mathrm{CD}_{3} \mathrm{OD}$ ) 


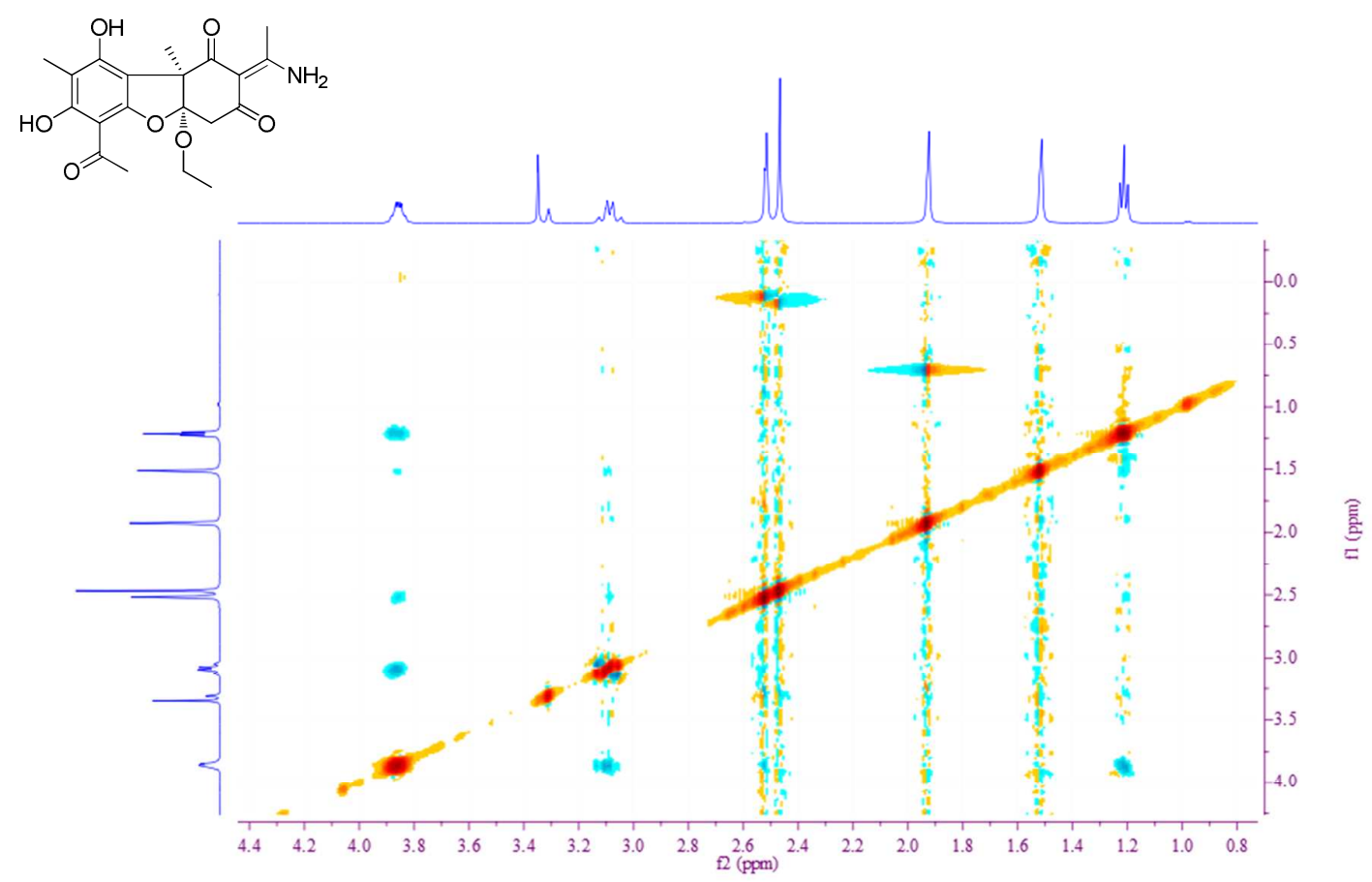

S13 NOESY spectrum of compound 2 (Measured in $\mathrm{CD}_{3} \mathrm{OD}$ )

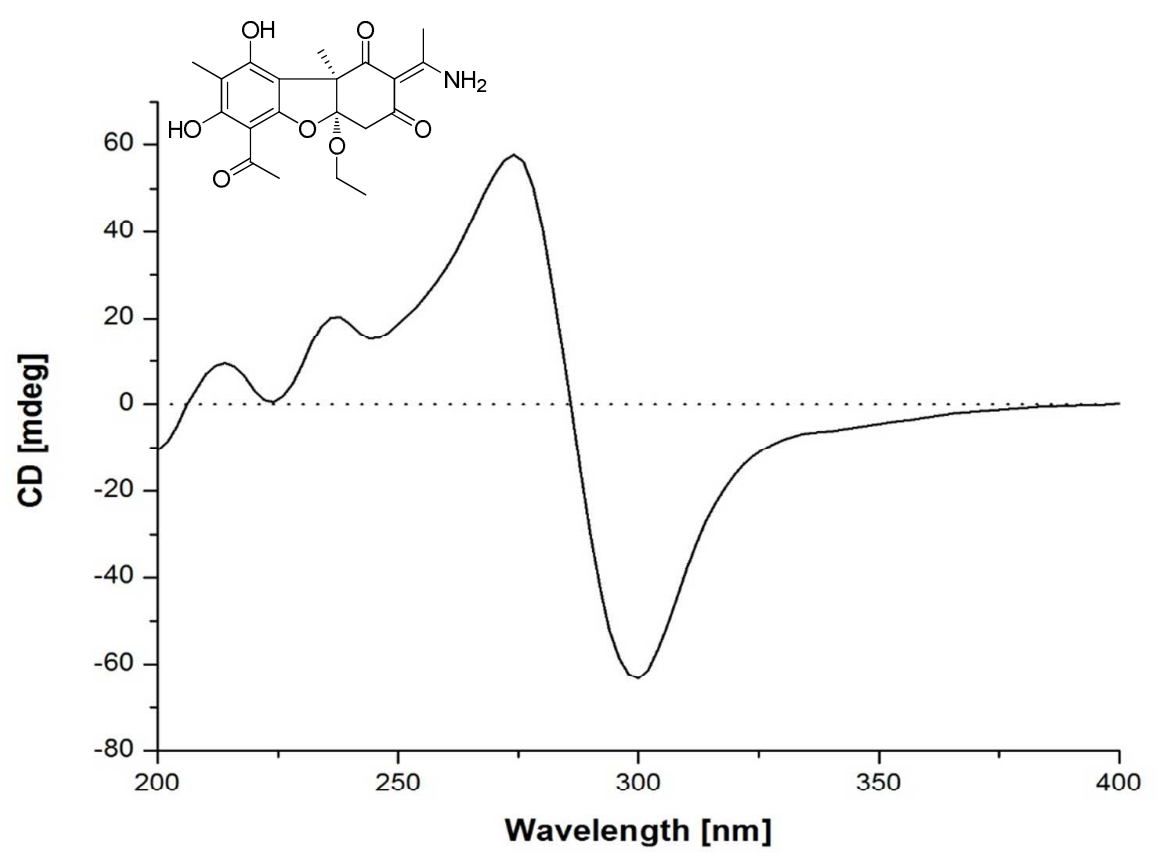

S14 CD spectrum of compound 2 (Measured in $\mathrm{CH}_{3} \mathrm{OH}$ ) 

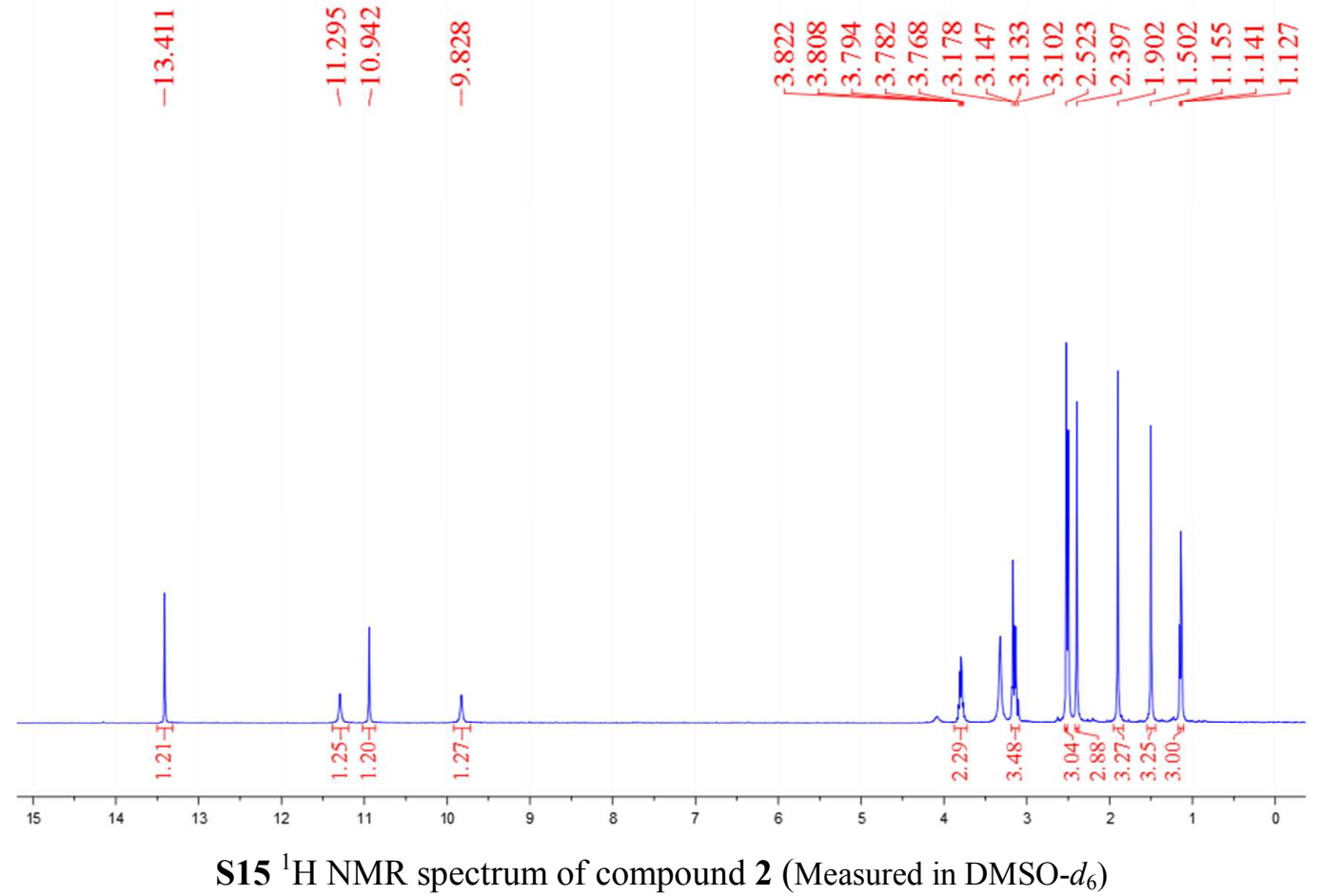
Data File: D:IDatas I于学龙IYXL-08_10.Icd

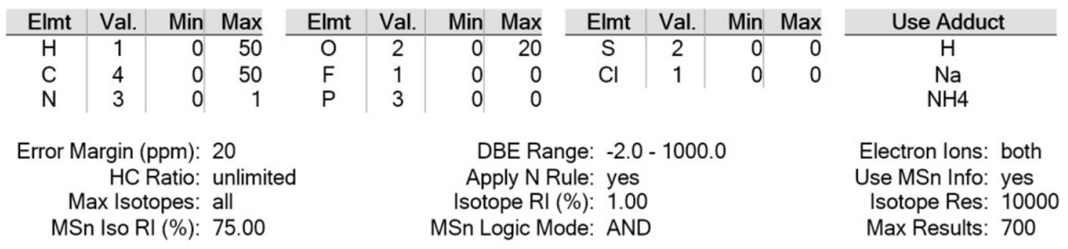

Event\#: $1 \mathrm{MS}(\mathrm{E}+)$ Ret. Time : 19.707 Scan\# : 2957

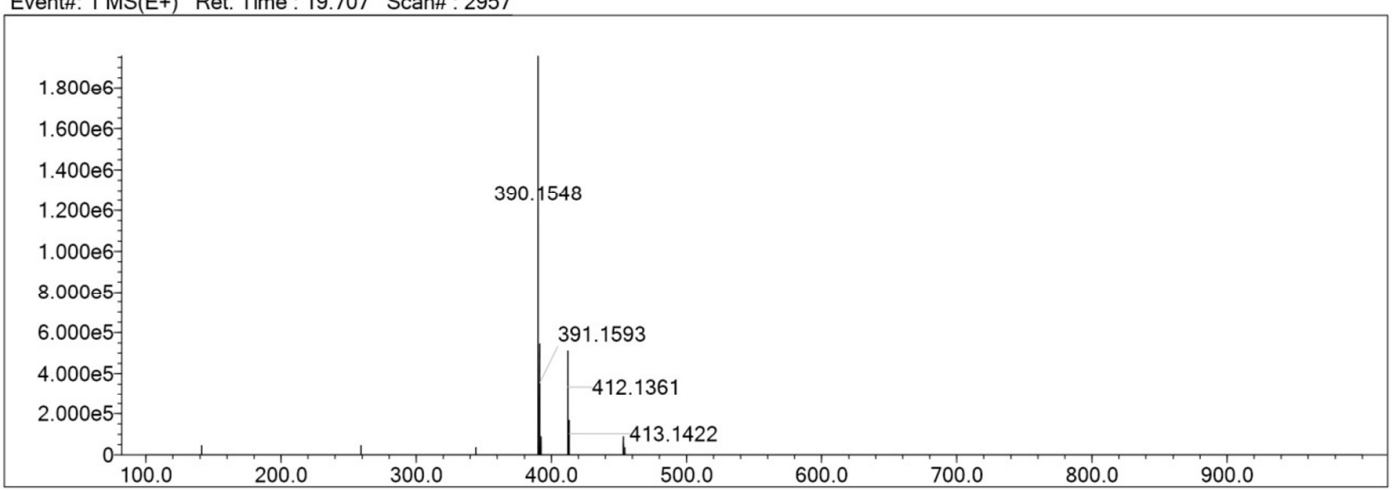

Measured region for $390.1548 \mathrm{~m} / \mathrm{z}$

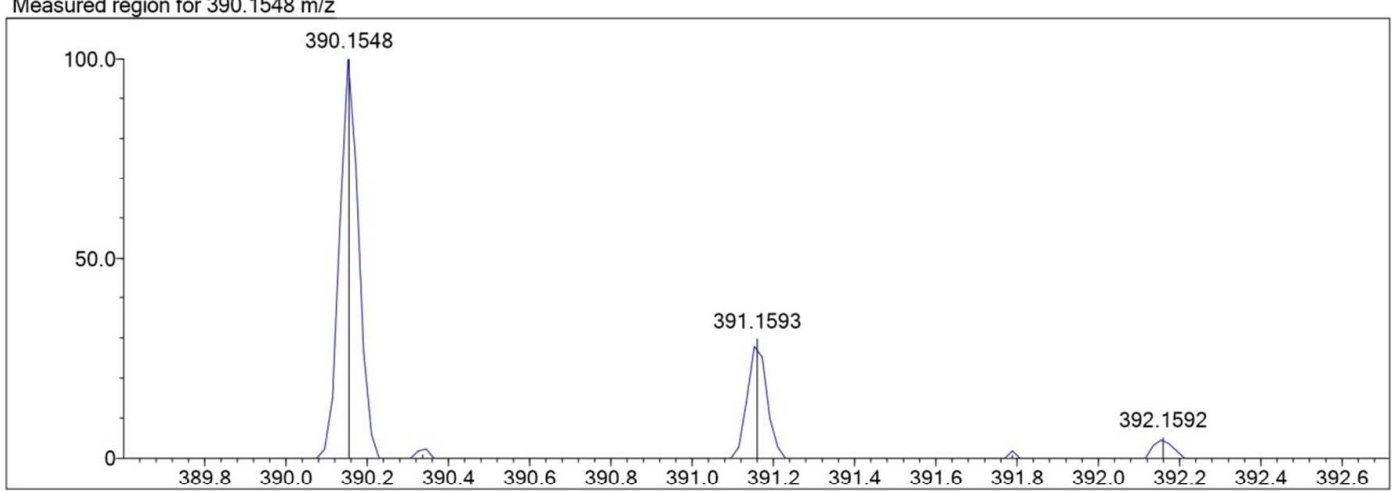

$\mathrm{C} 20 \mathrm{H} 23 \mathrm{~N} \mathrm{O} 7[\mathrm{M}+\mathrm{H}]+$ : Predicted region for $390.1547 \mathrm{~m} / \mathrm{z}$

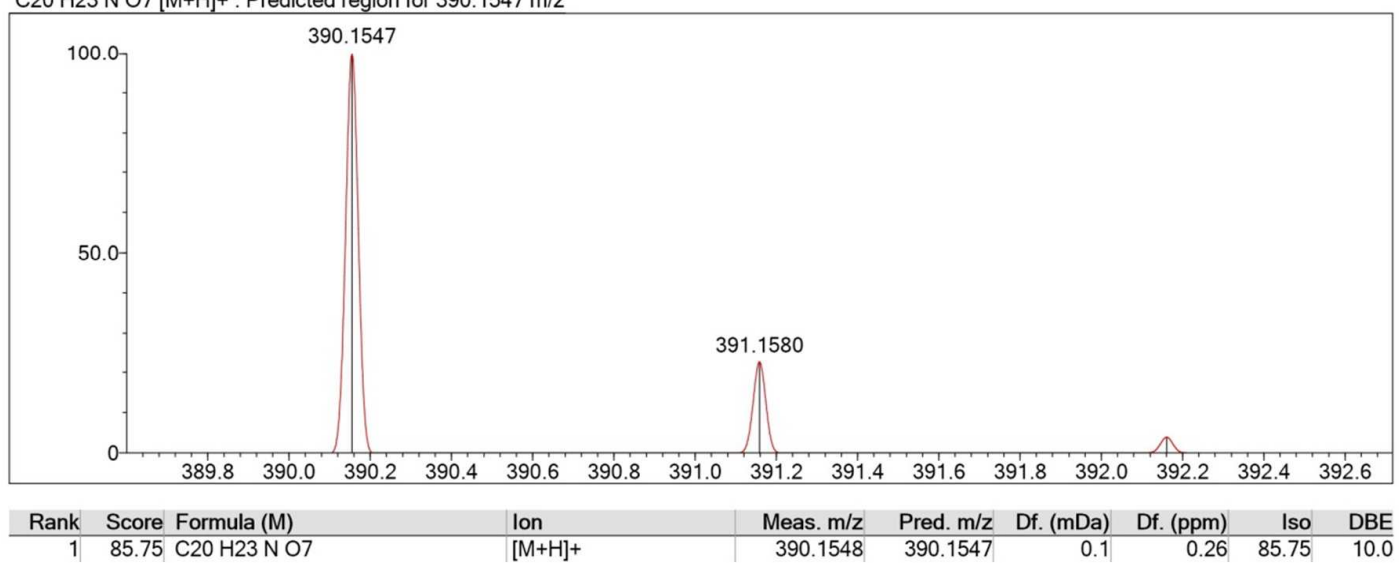

\section{S16 HRESIMS spectrum of compound $\mathbf{3}$}



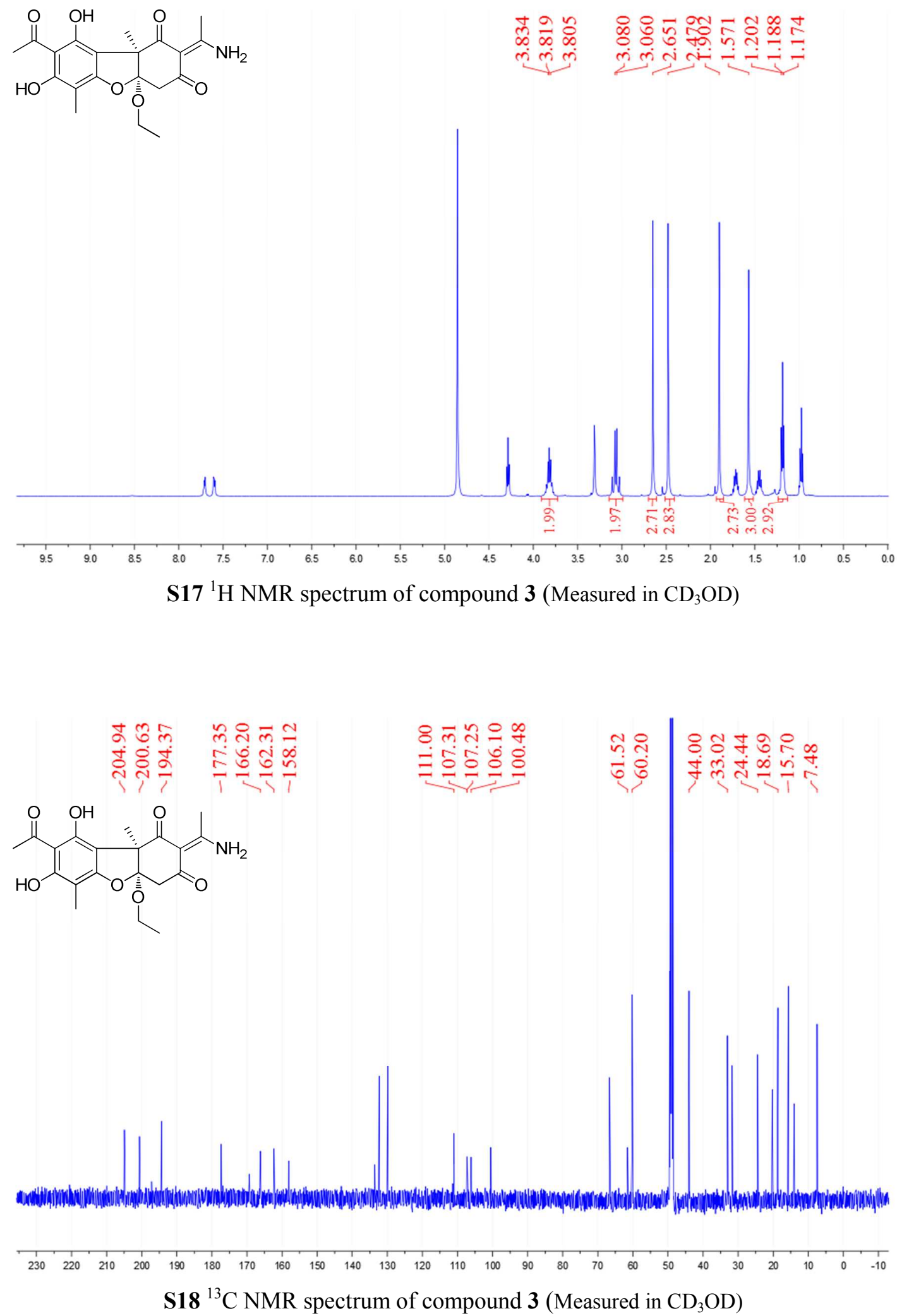


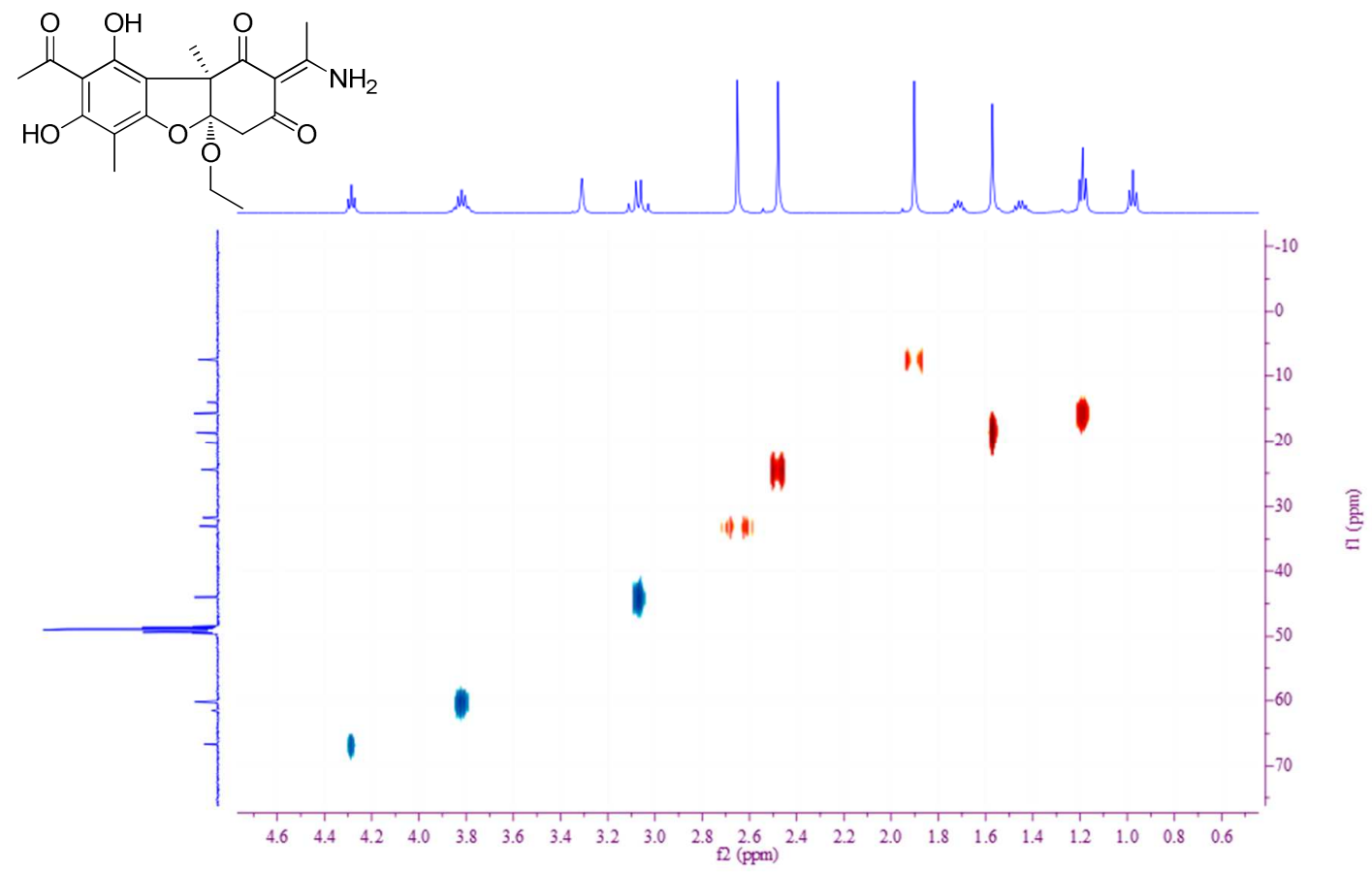

S19 gHSQC spectrum of compound 3 (Measured in $\mathrm{CD}_{3} \mathrm{OD}$ )

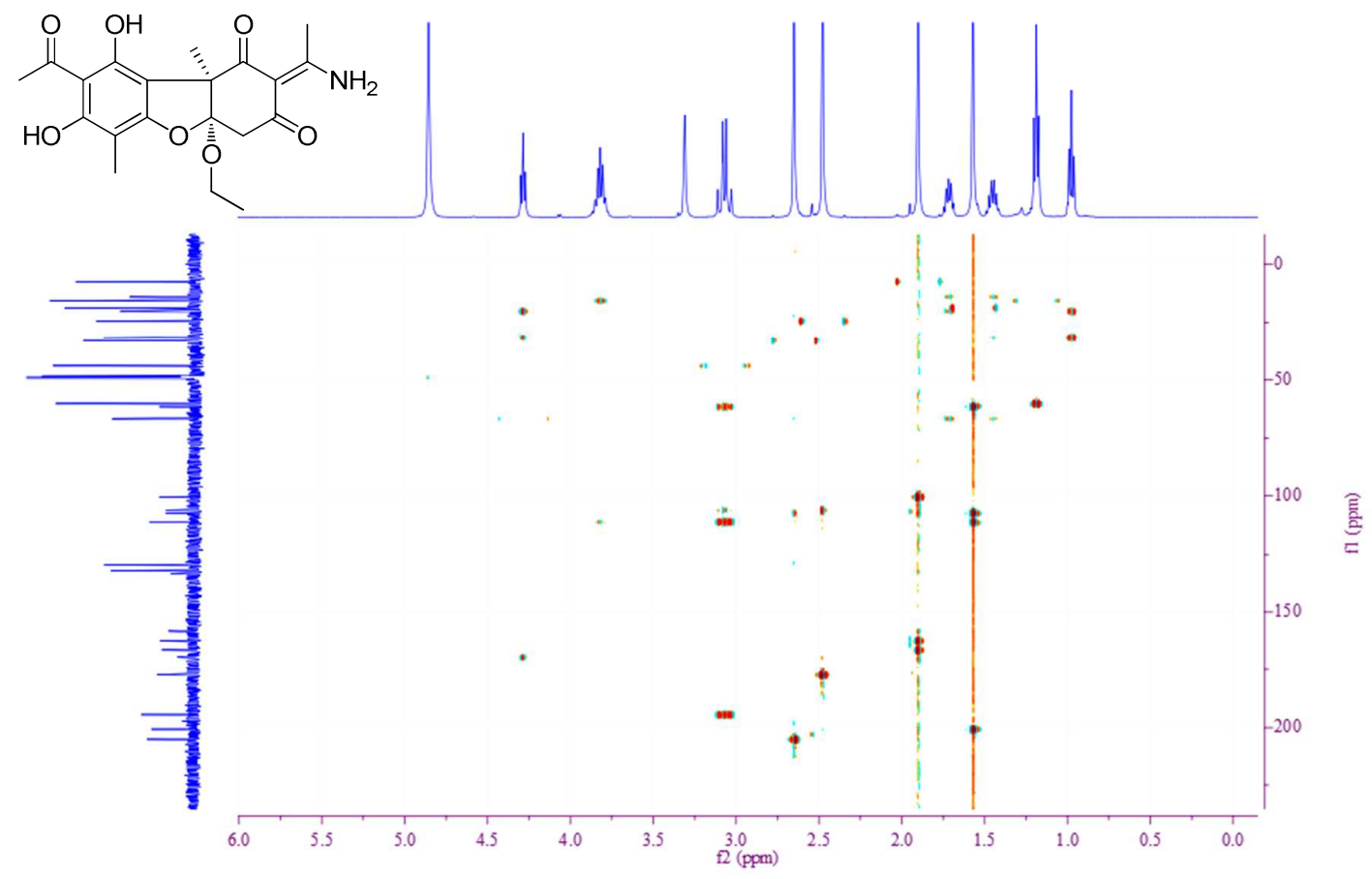

S20 gHMBC spectrum of compound 3 (Measured in $\mathrm{CD}_{3} \mathrm{OD}$ ) 


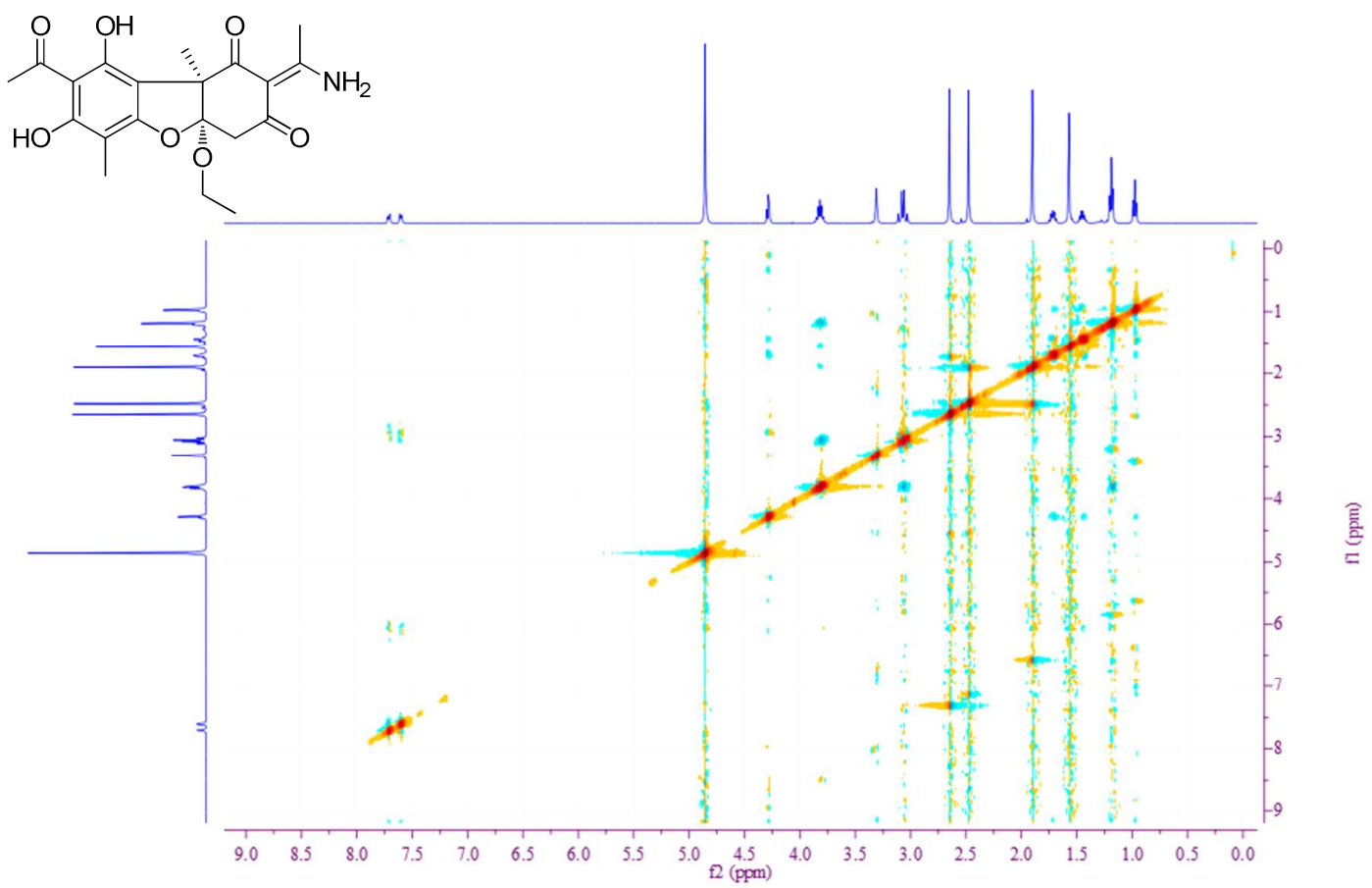

S21 NOESY spectrum of compound 3 (Measured in $\mathrm{CD}_{3} \mathrm{OD}$ )

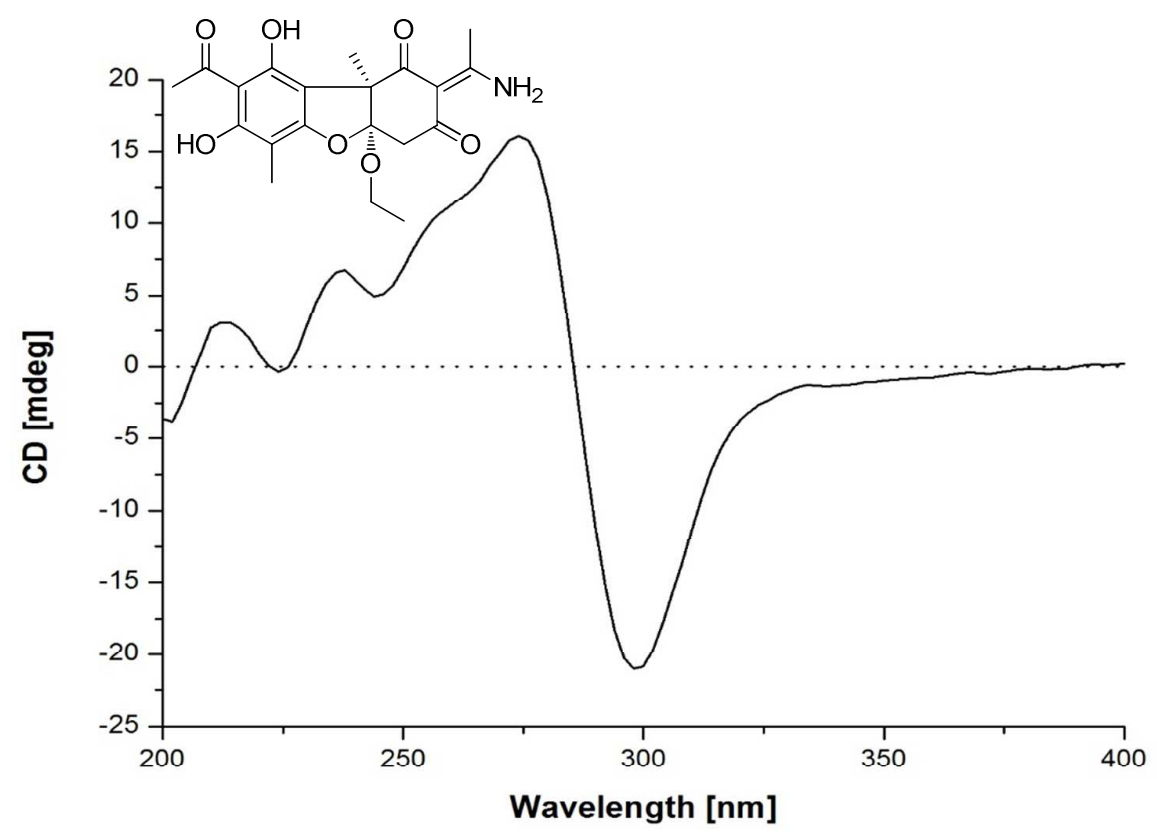

S22 CD spectrum of compound 3 (Measured in $\mathrm{CH}_{3} \mathrm{OH}$ ) 
Data File: D:IDatas I于学龙1新建文件夹IYXL-04.Icd

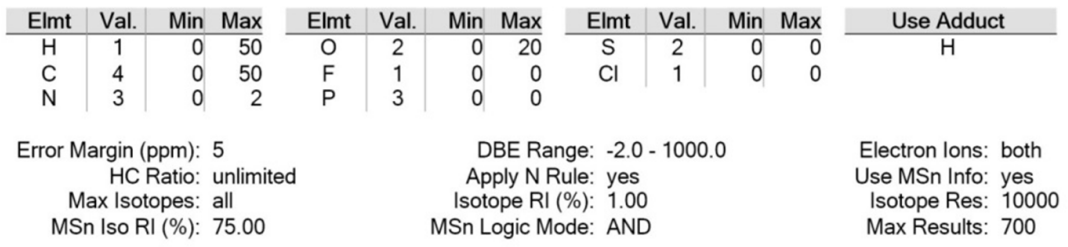

Event\#: 1 MS(E+) Ret. Time : 59.423 -> 59.575 - 59.423 <-> 59.575 Scan\# : 6477 -> 6491 - 6477 <-> 6491

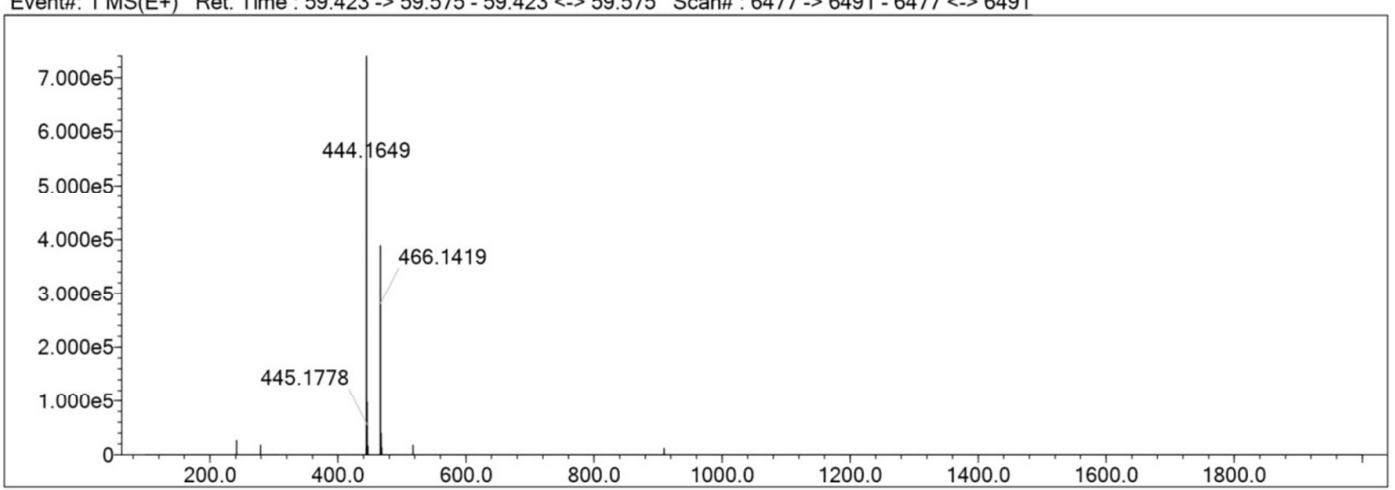

Measured region for $444.1649 \mathrm{~m} / \mathrm{z}$

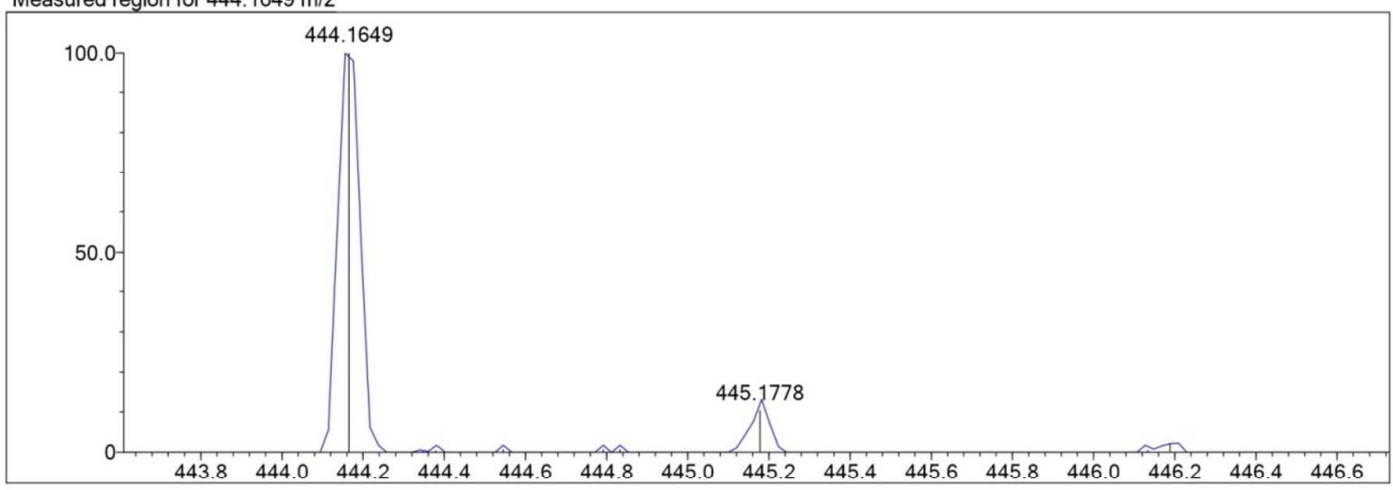

$\mathrm{C} 23 \mathrm{H} 25 \mathrm{~N} \mathrm{O} 8[\mathrm{M}+\mathrm{H}]+$ : Predicted region for $444.1653 \mathrm{~m} / \mathrm{z}$

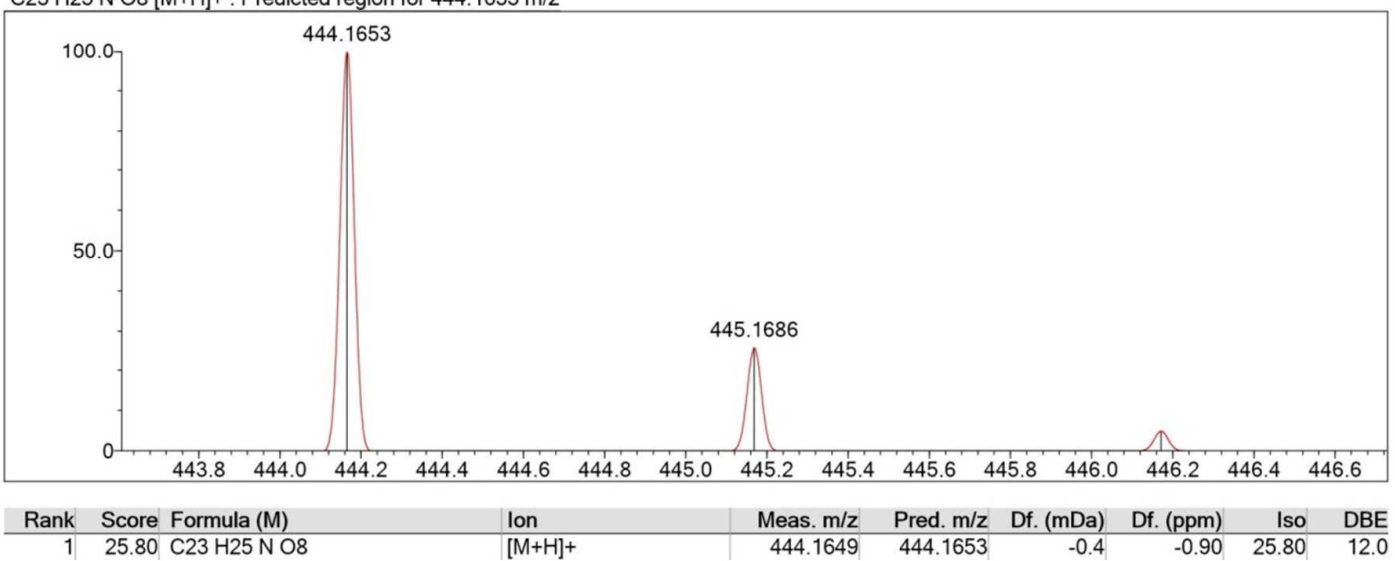

\section{S23 HRESIMS spectrum of compound 4}



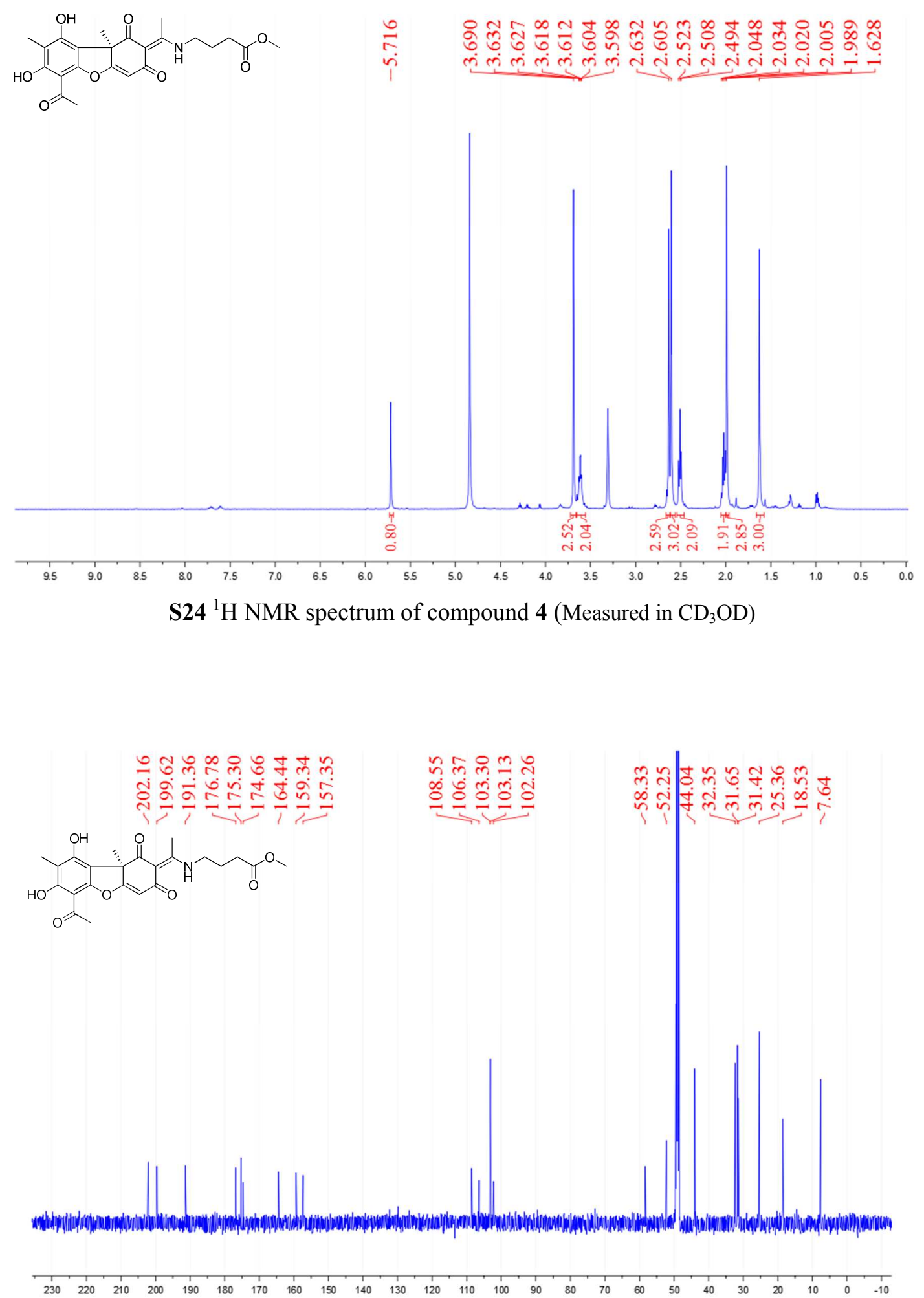

S25 ${ }^{13} \mathrm{C}$ NMR spectrum of compound 4 (Measured in $\mathrm{CD}_{3} \mathrm{OD}$ ) 


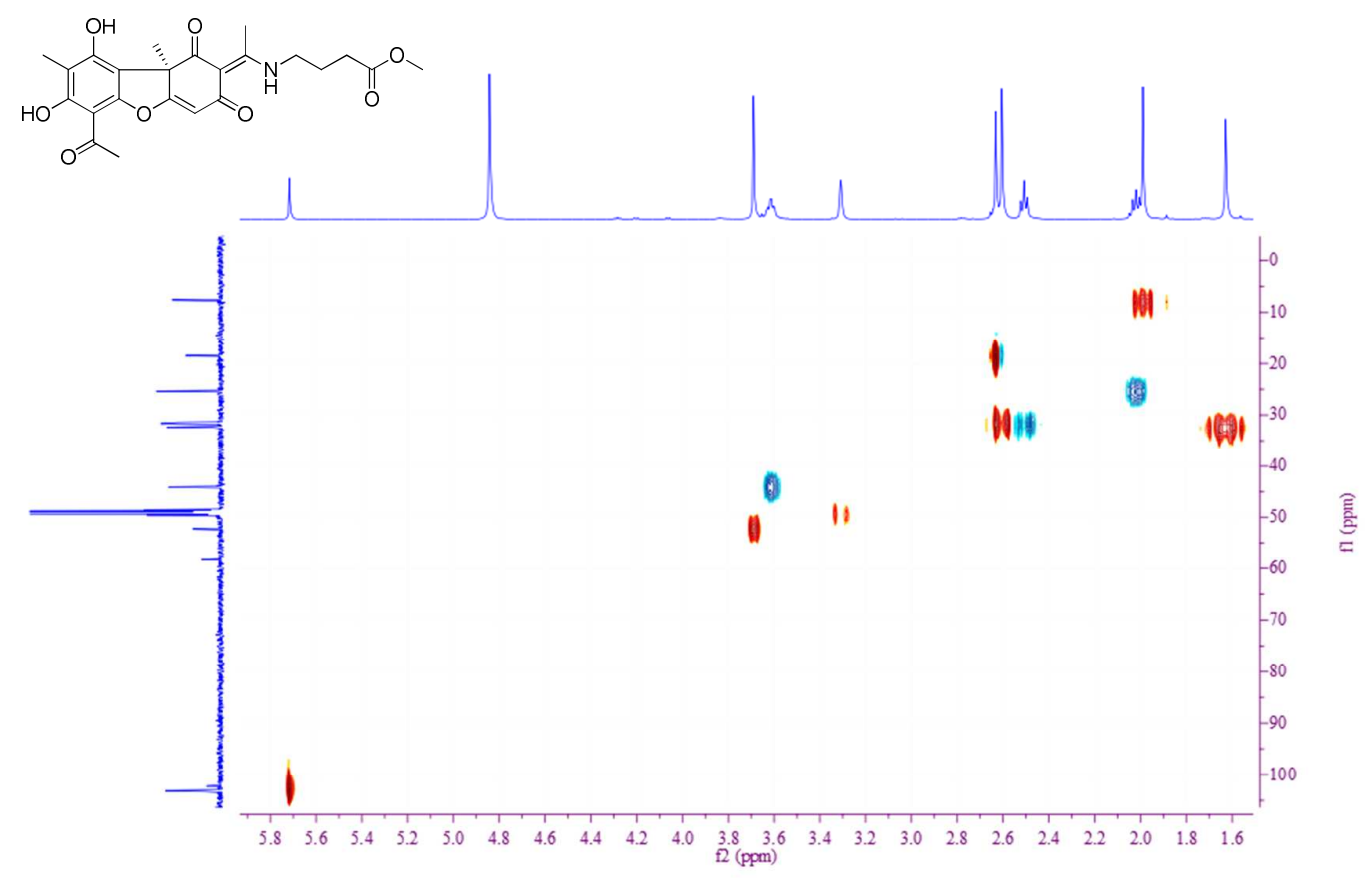

S26 gHSQC spectrum of compound 4 (Measured in $\mathrm{CD}_{3} \mathrm{OD}$ )

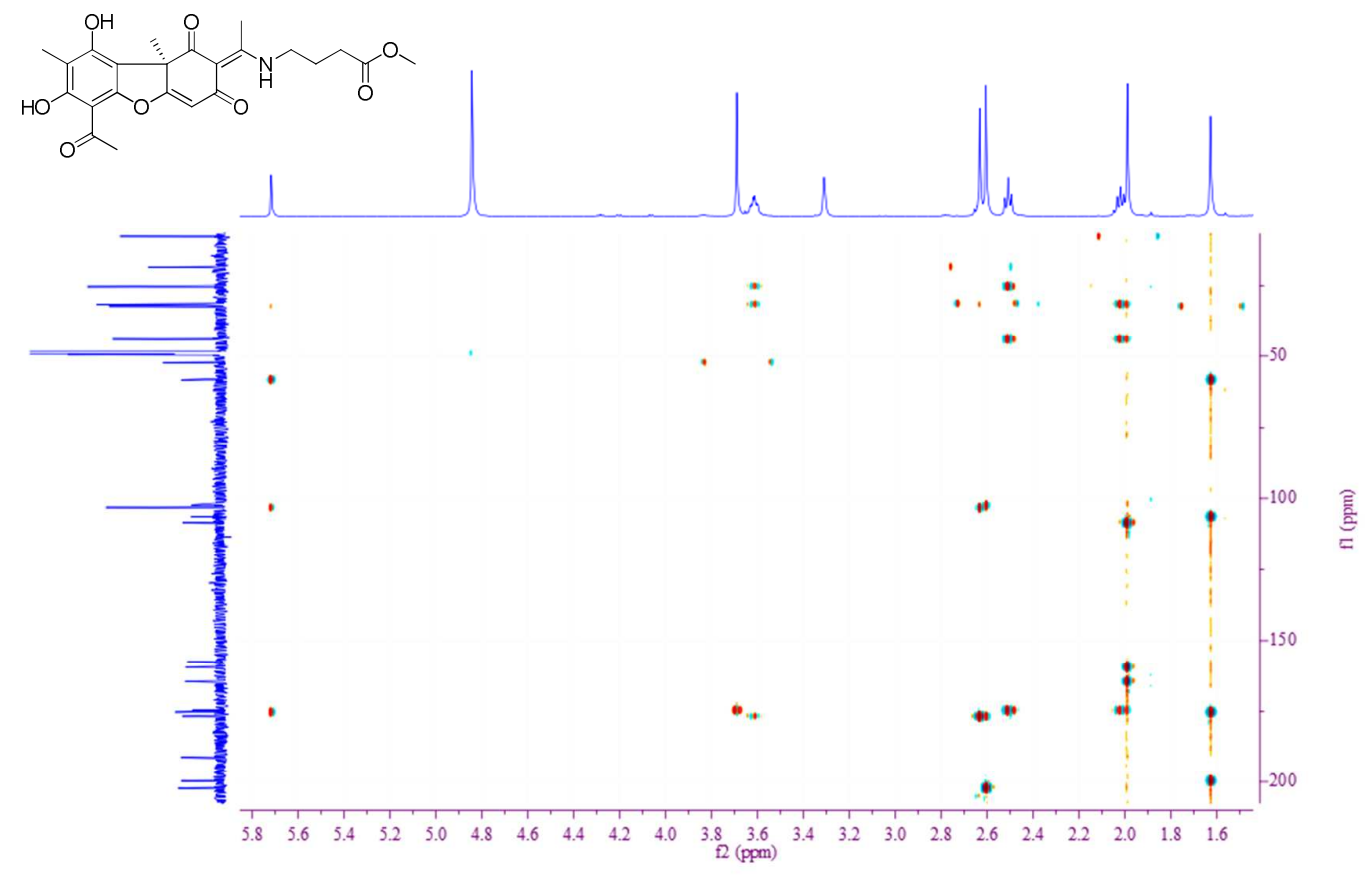

S27 gHMBC spectrum of compound 4 (Measured in $\mathrm{CD}_{3} \mathrm{OD}$ ) 


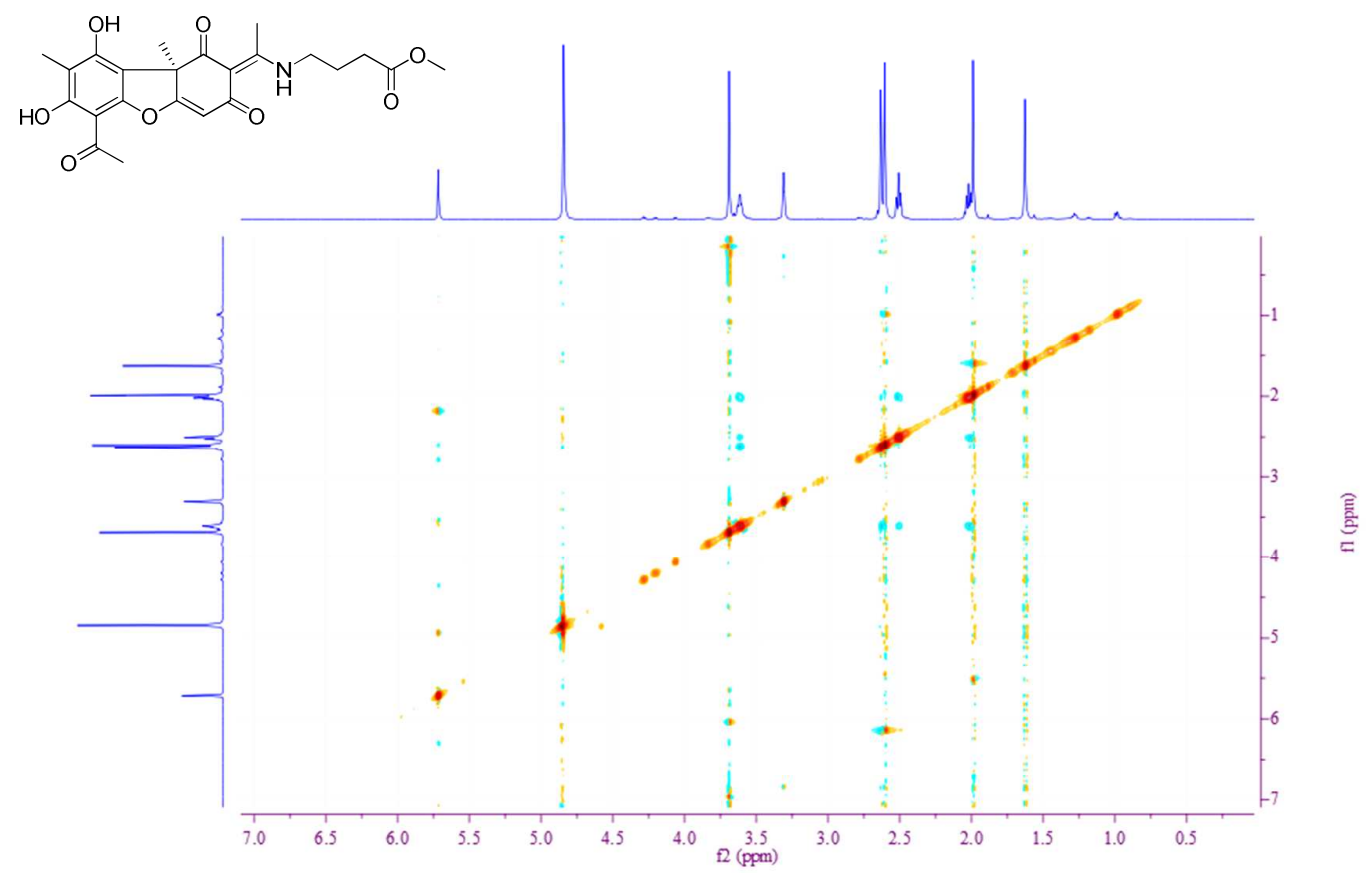

S28 NOESY spectrum of compound 4 (Measured in $\mathrm{CD}_{3} \mathrm{OD}$ )
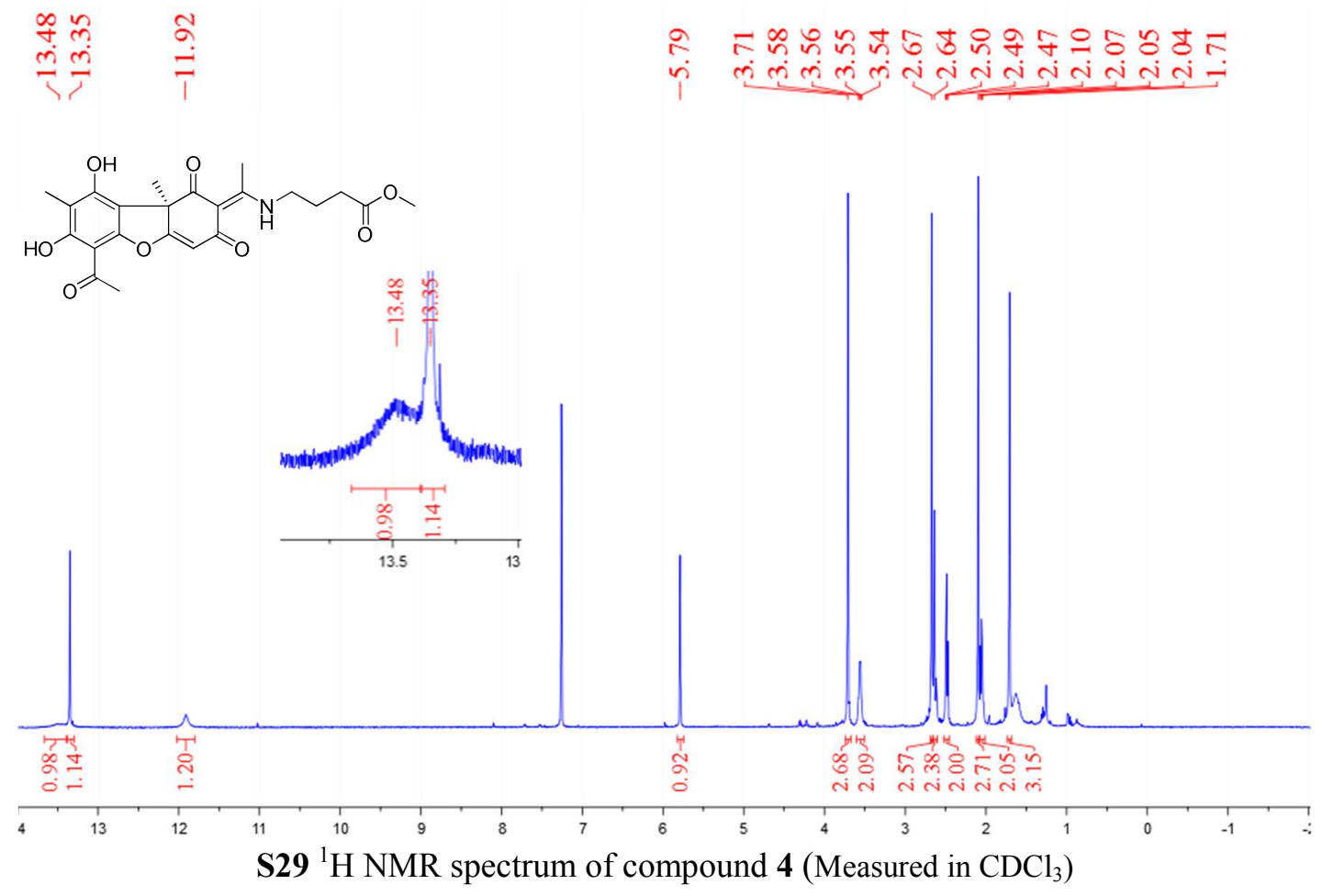

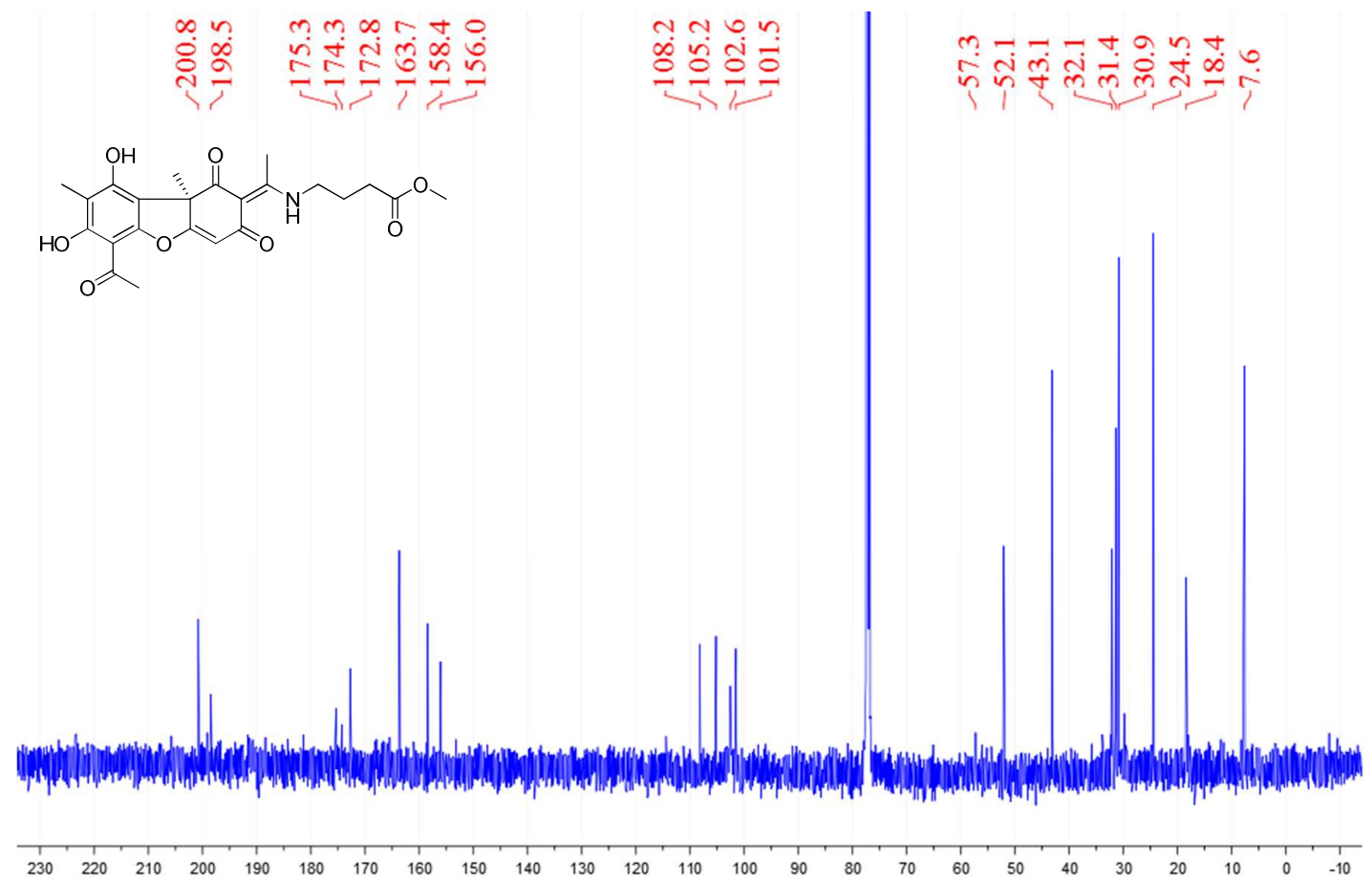

S30 ${ }^{13} \mathrm{C}$ NMR spectrum of compound 4 (Measured in $\mathrm{CDCl}_{3}$ )

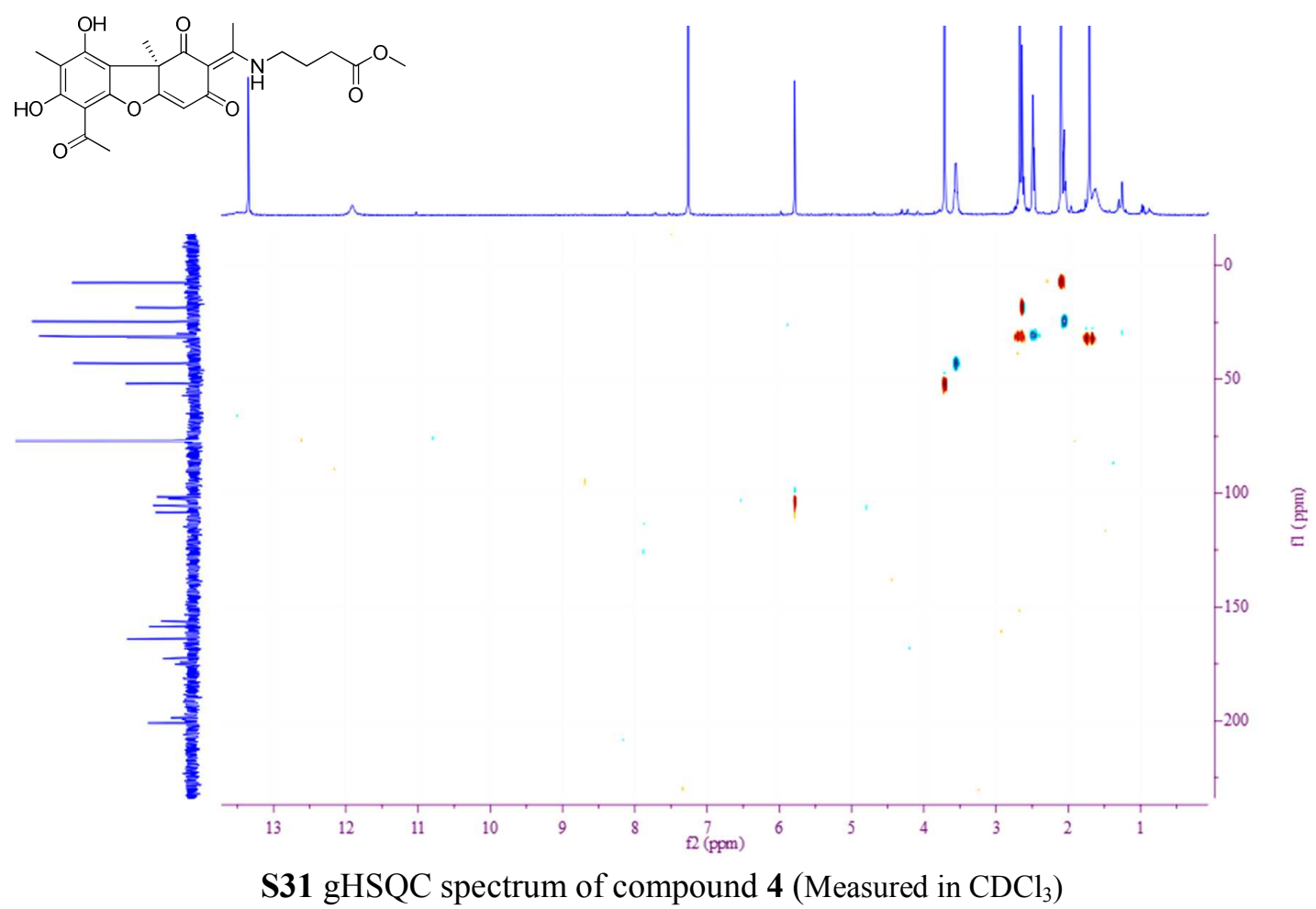



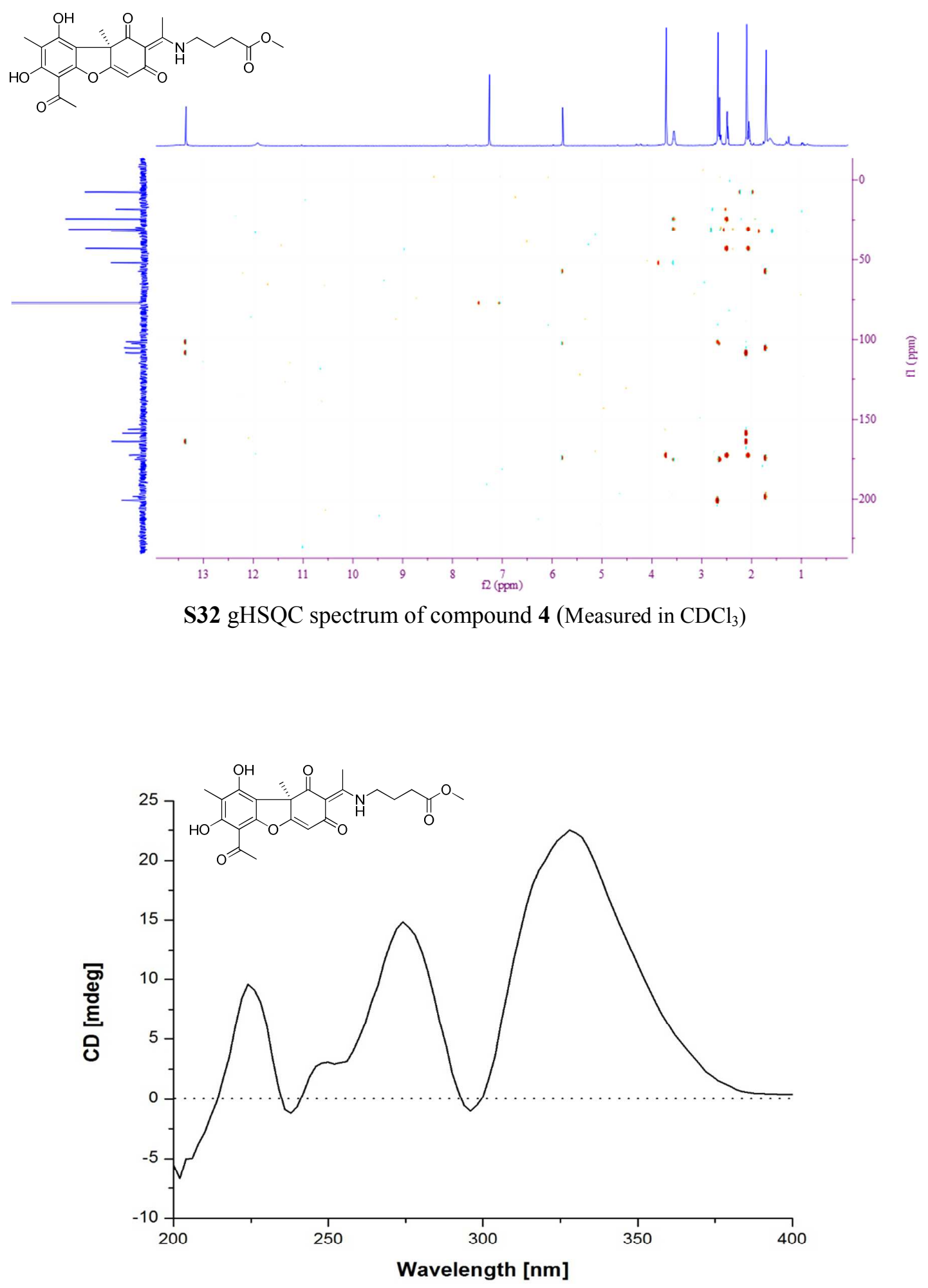

S33 CD spectrum of compound 4 (Measured in $\mathrm{CH}_{3} \mathrm{OH}$ ) 
Data File: D:IDatasI于学龙IYXL-06_9.Icd

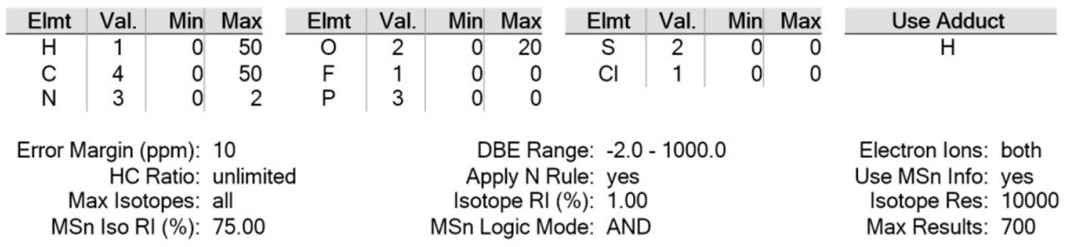

Event\#: $1 \mathrm{MS}(\mathrm{E}+)$ Ret. Time : 21.760 Scan\# : 3265

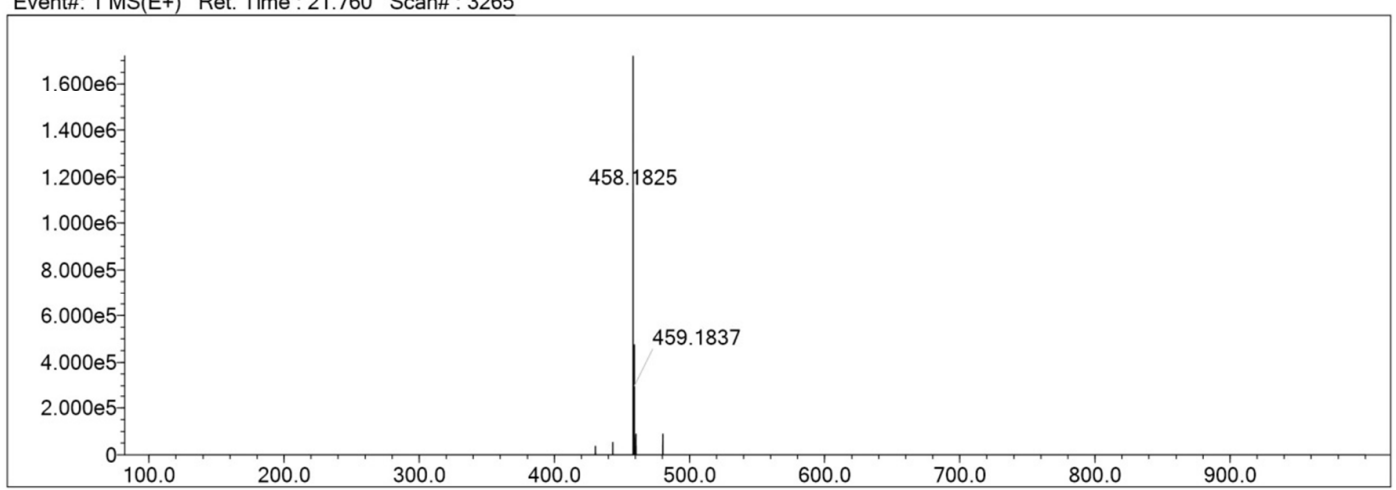

Measured region for $458.1825 \mathrm{~m} / \mathrm{z}$

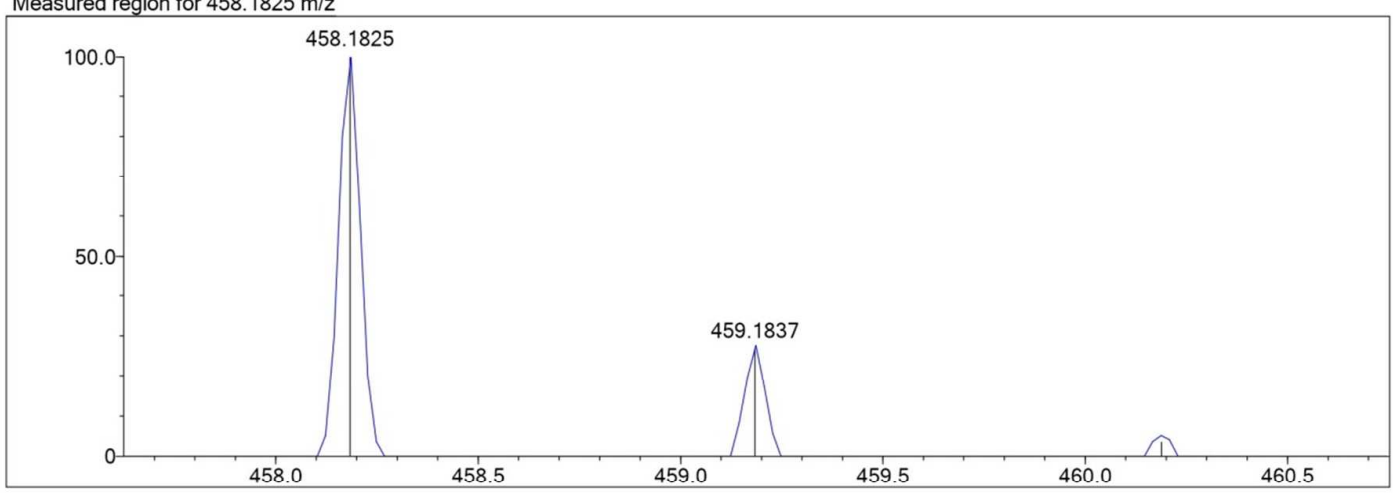

$\mathrm{C} 24 \mathrm{H} 27 \mathrm{~N} \mathrm{O} 8[\mathrm{M}+\mathrm{H}]+$ : Predicted region for $458.1809 \mathrm{~m} / \mathrm{z}$

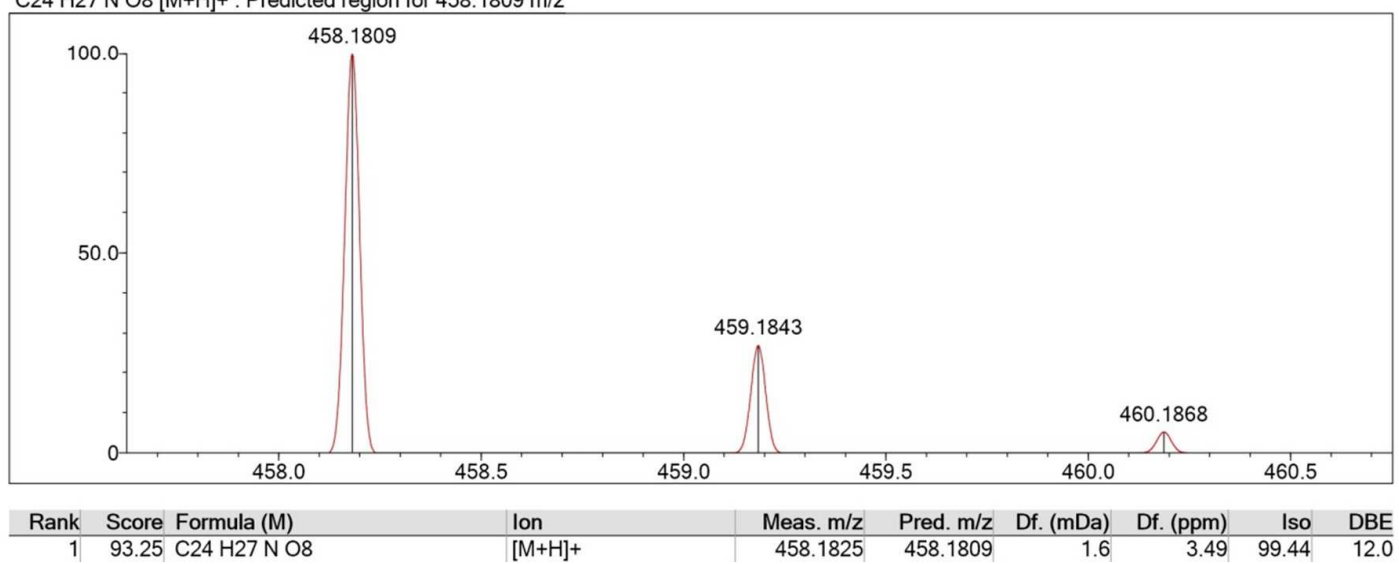

\section{S34 HRESIMS spectrum of compound 5}



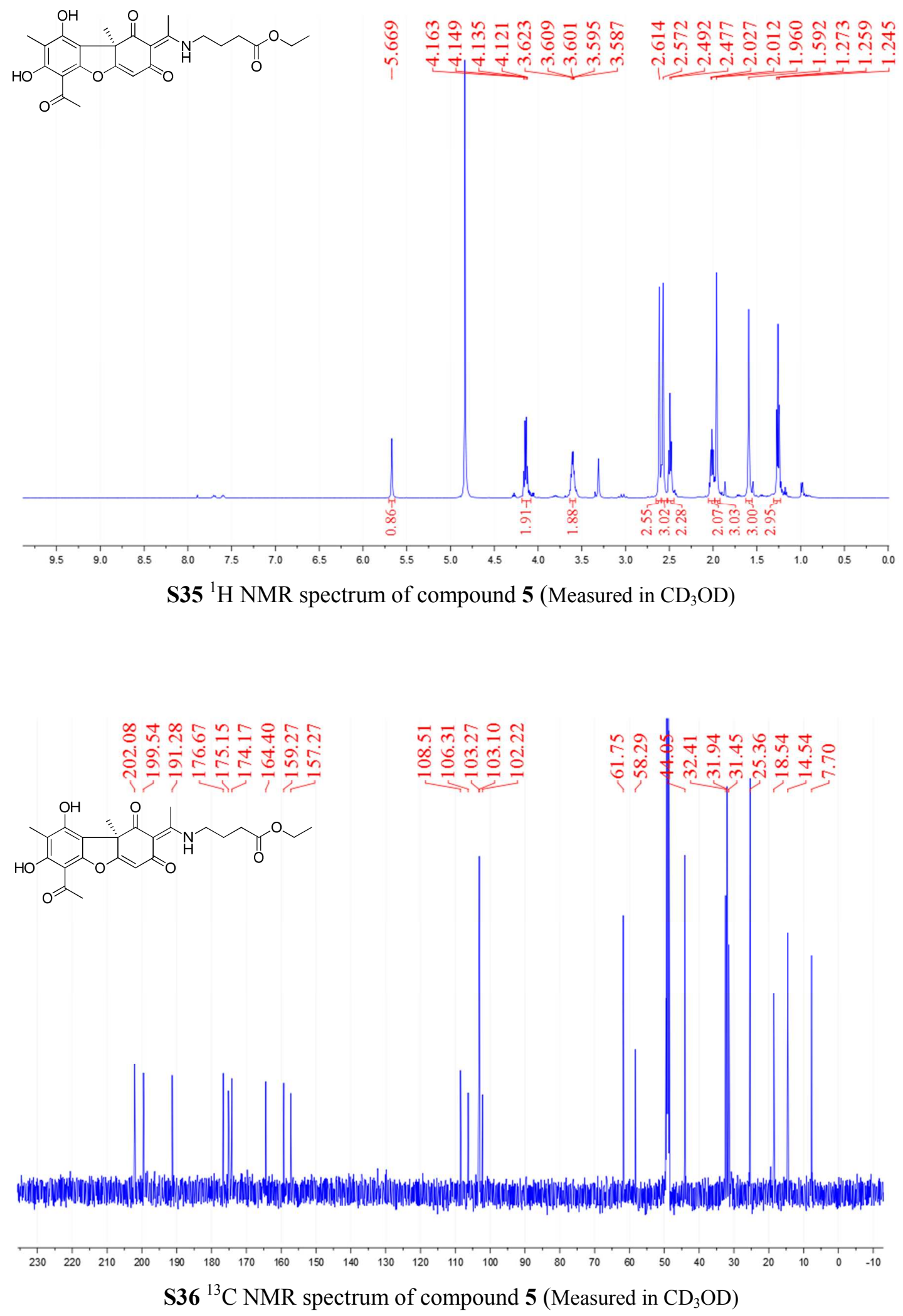

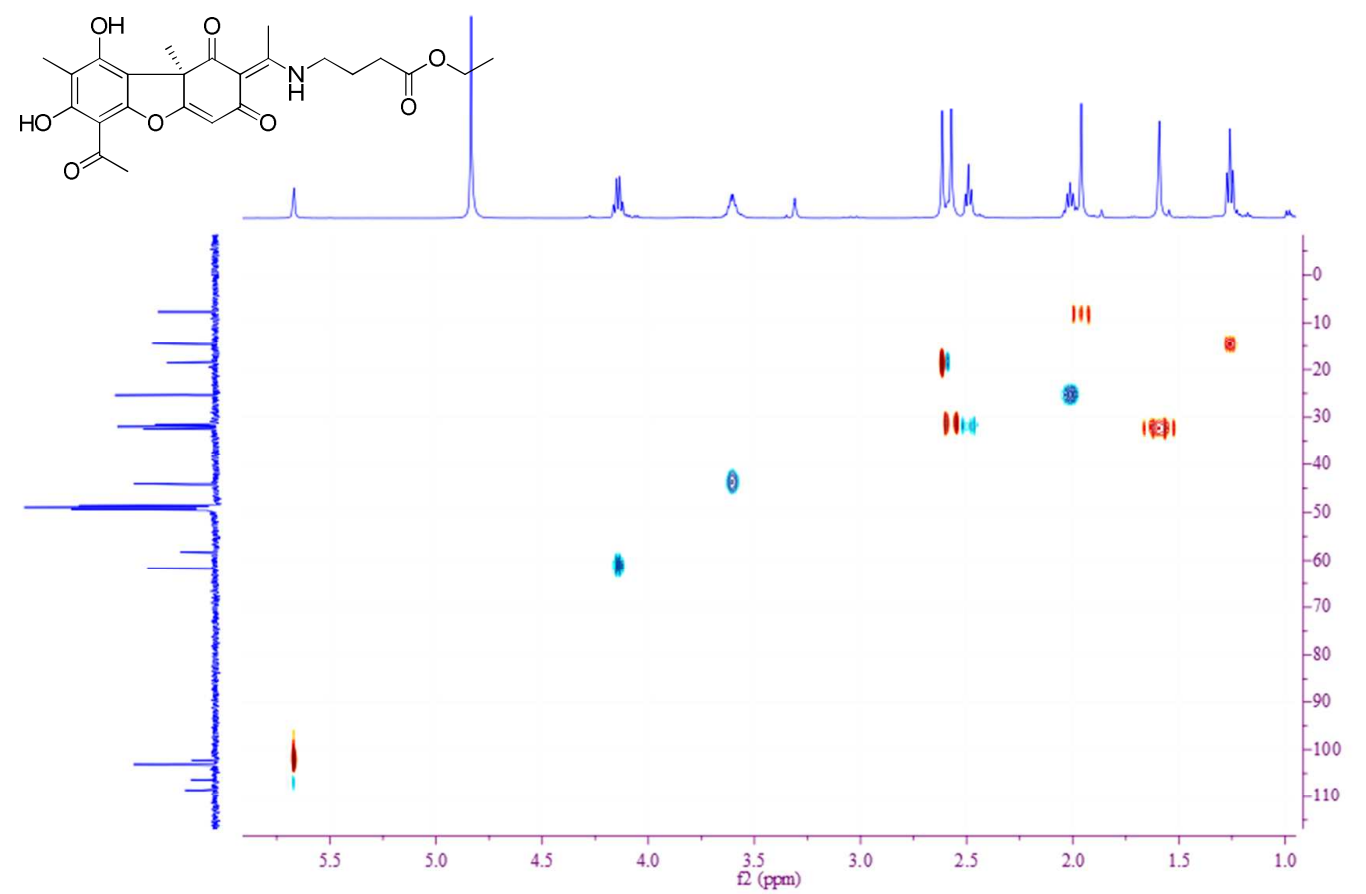

S37 gHSQC spectrum of compound 5 (Measured in $\mathrm{CD}_{3} \mathrm{OD}$ )

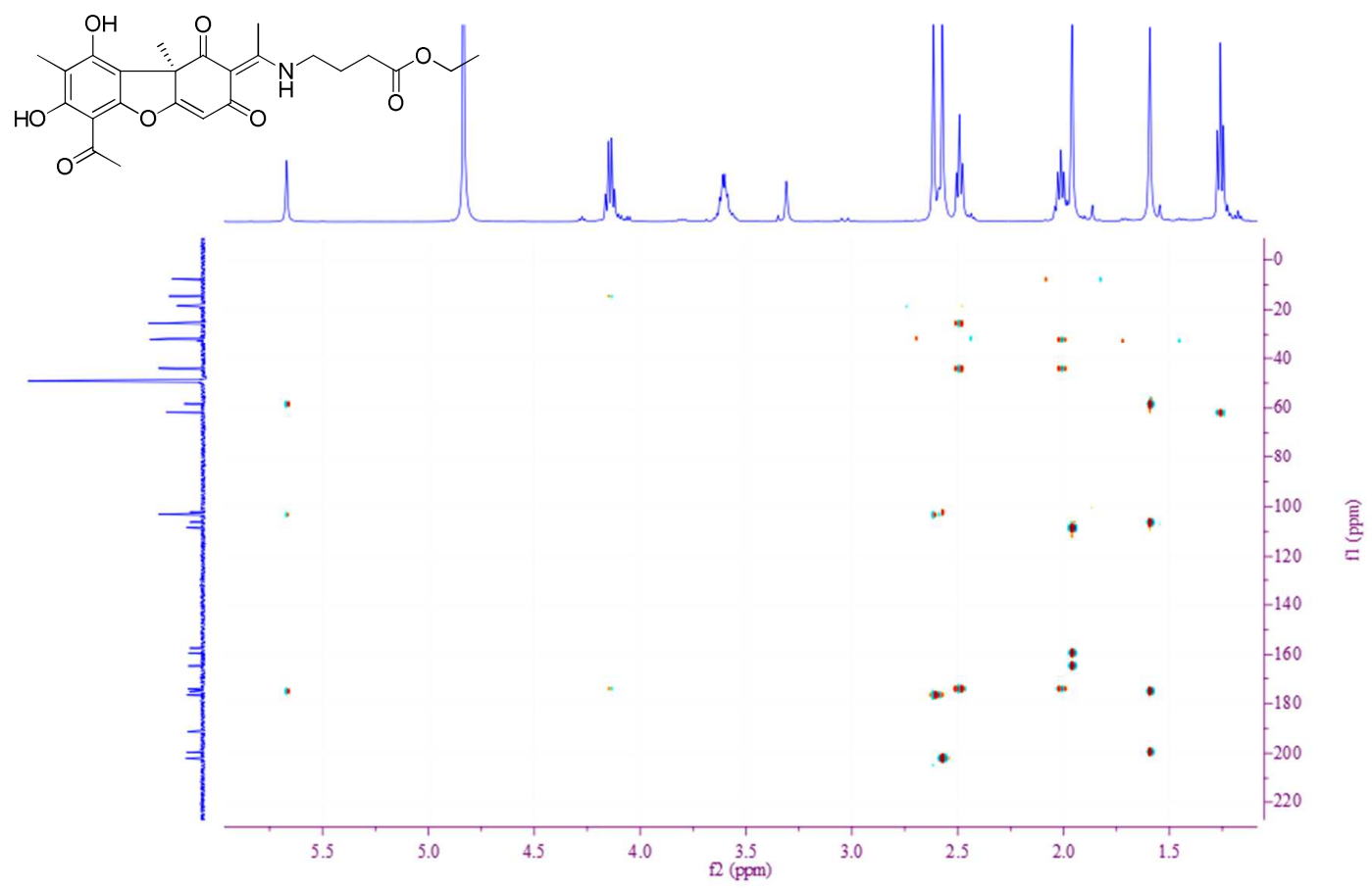

S38 gHMBC spectrum of compound 5 (Measured in $\mathrm{CD}_{3} \mathrm{OD}$ ) 


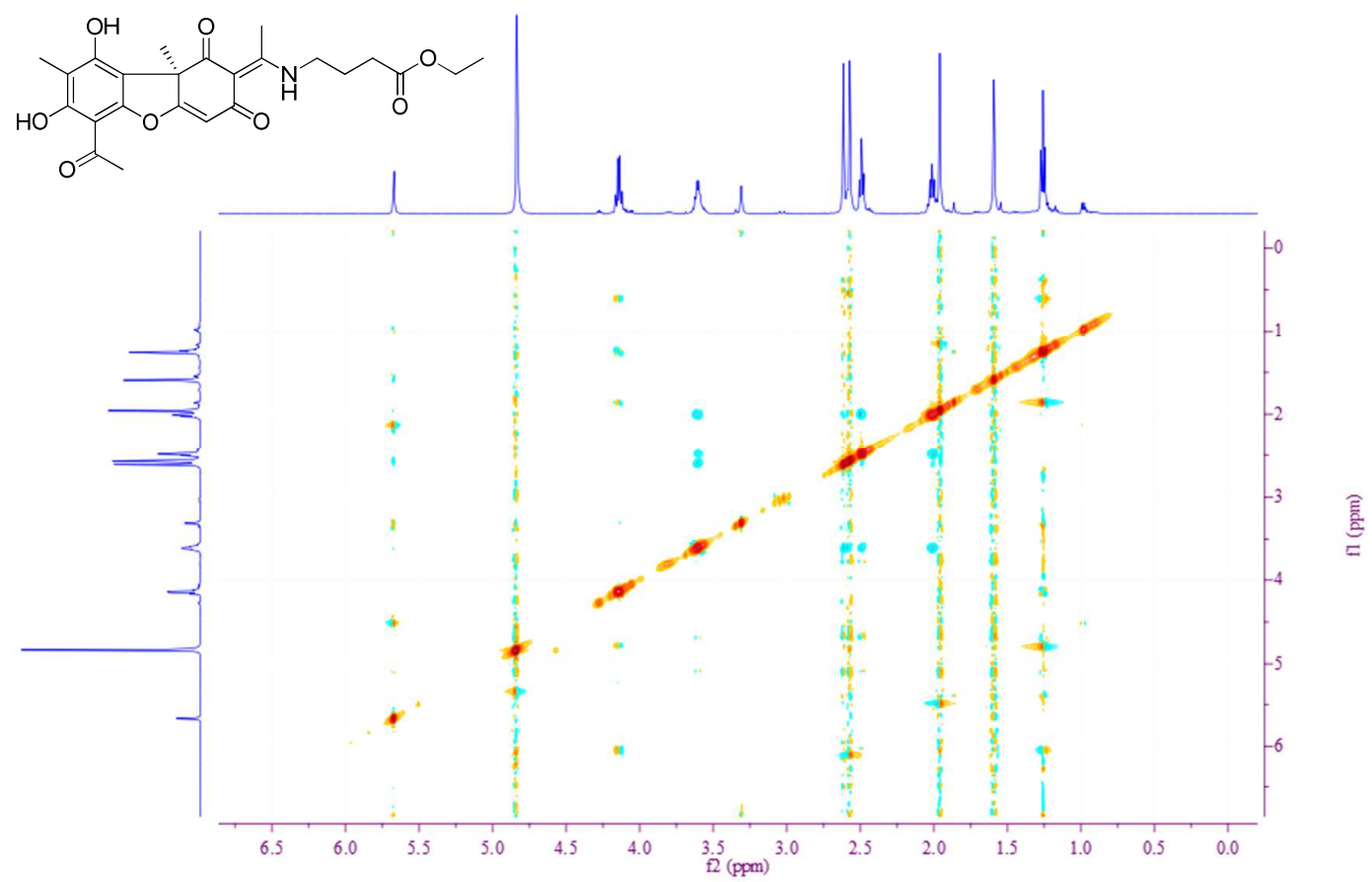

S39 NOESY spectrum of compound $\mathbf{5}$ (Measured in $\mathrm{CD}_{3} \mathrm{OD}$ )

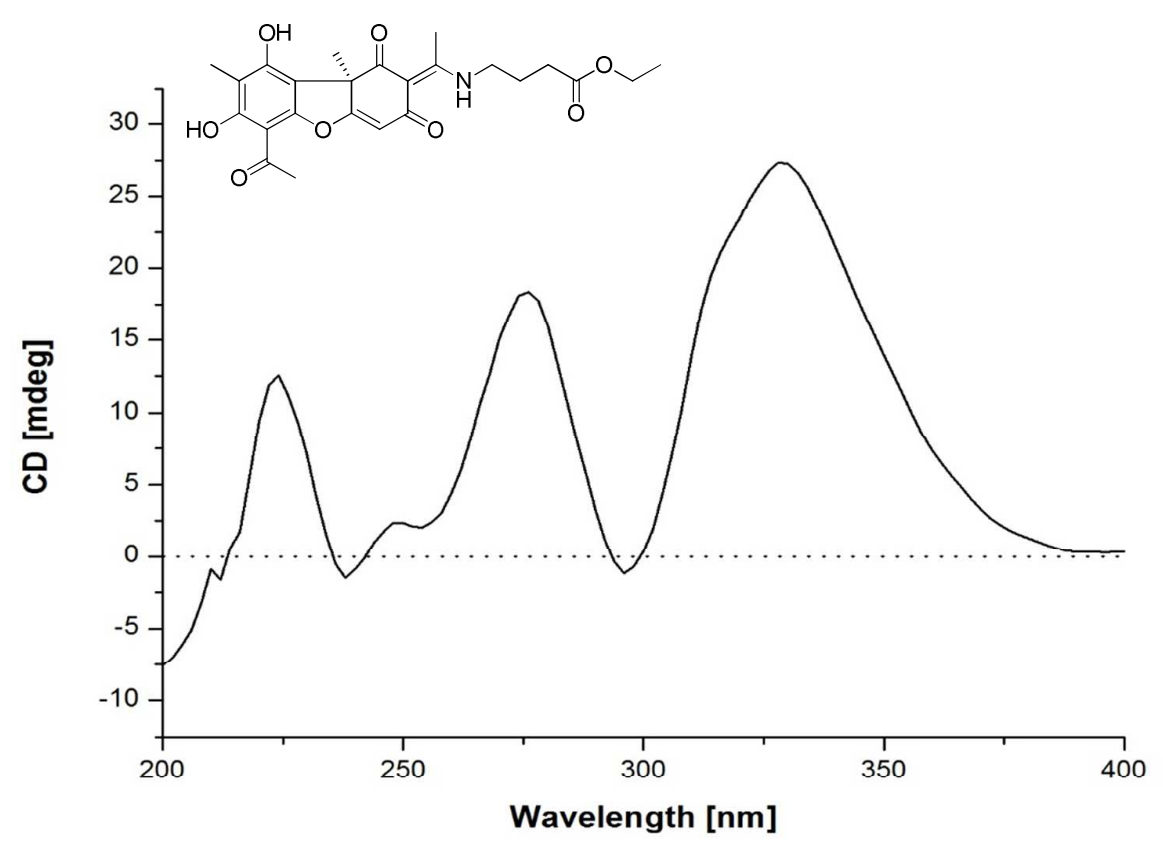

S40 CD spectrum of compound 5 (Measured in $\mathrm{CH}_{3} \mathrm{OH}$ ) 
Data File: D:IDatas|于学龙1新建文件夹IYXL-05.Icd

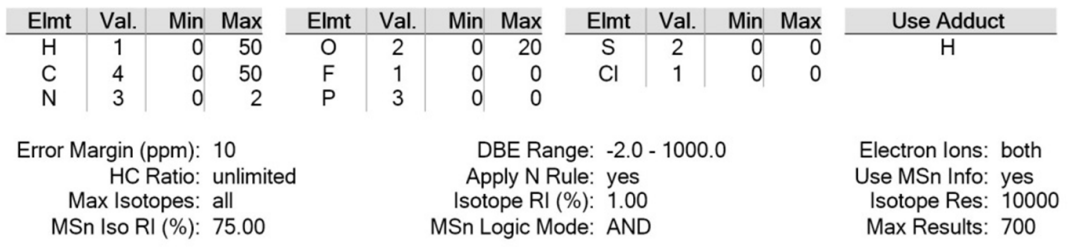

Event\#: $1 \mathrm{MS}(\mathrm{E}+)$ Ret. Time : 81.543 Scan\# : 8649

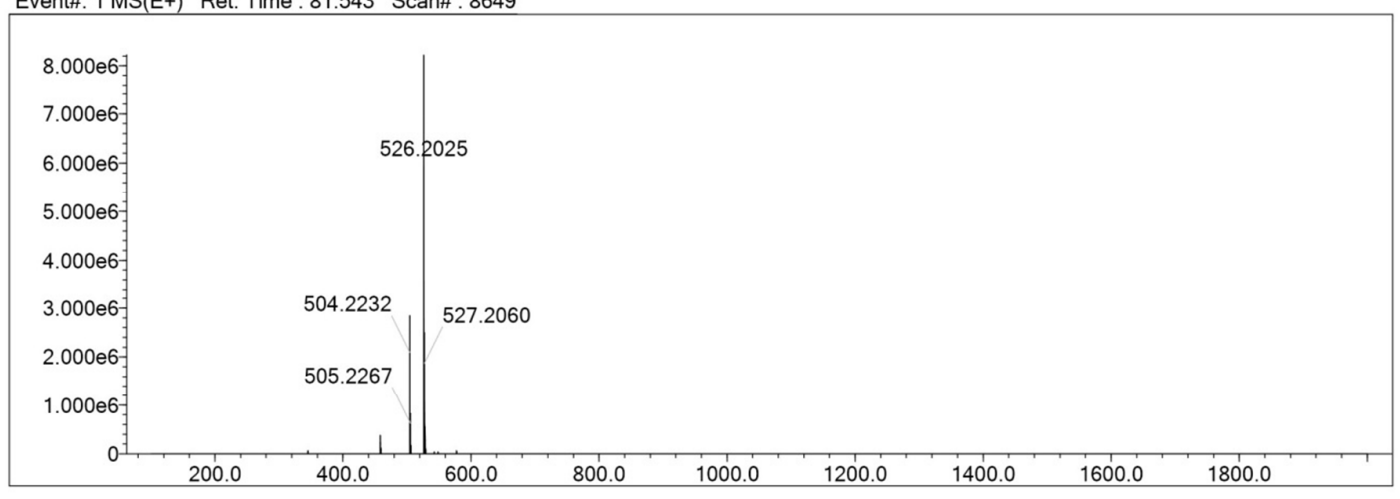

Measured region for $504.2232 \mathrm{~m} / \mathrm{z}$

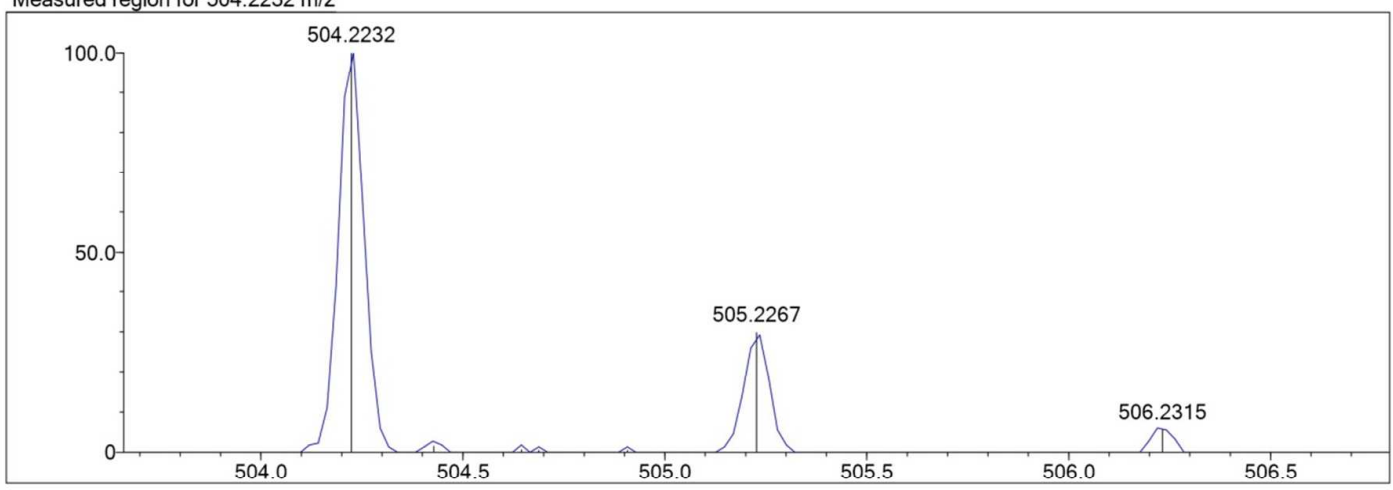

$\mathrm{C} 26 \mathrm{H} 33 \mathrm{~N} \mathrm{O} 9[\mathrm{M}+\mathrm{H}]+$ : Predicted region for $504.2228 \mathrm{~m} / \mathrm{z}$

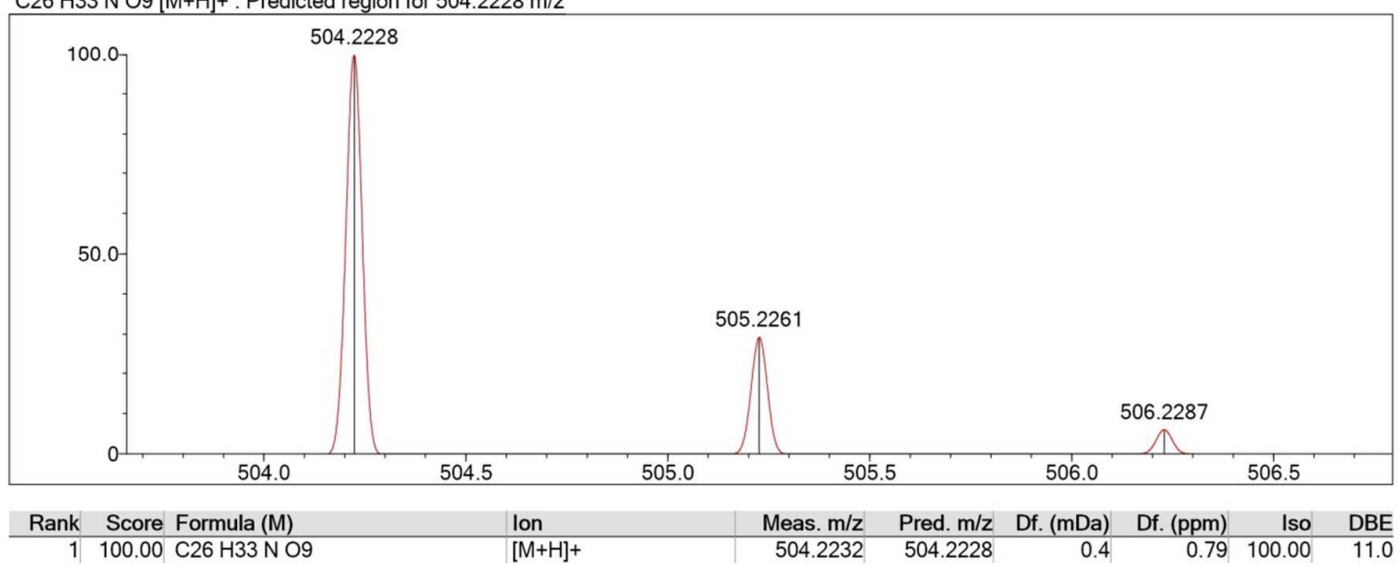

\section{S41 HRESIMS spectrum of compound $\mathbf{6}$}



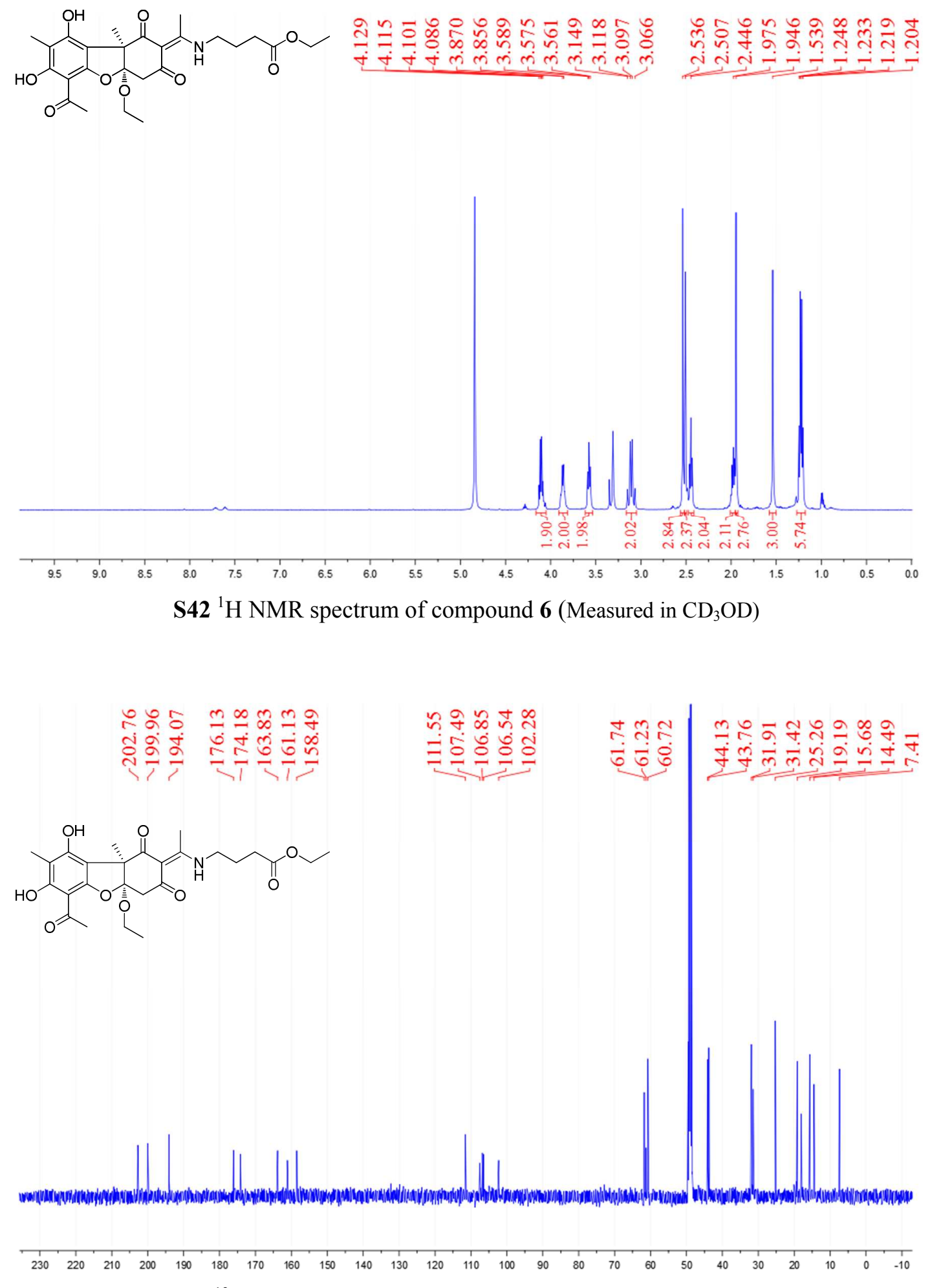

$\mathbf{S 4 3}{ }^{13} \mathrm{C}$ NMR spectrum of compound 6 (Measured in $\mathrm{CD}_{3} \mathrm{OD}$ ) 


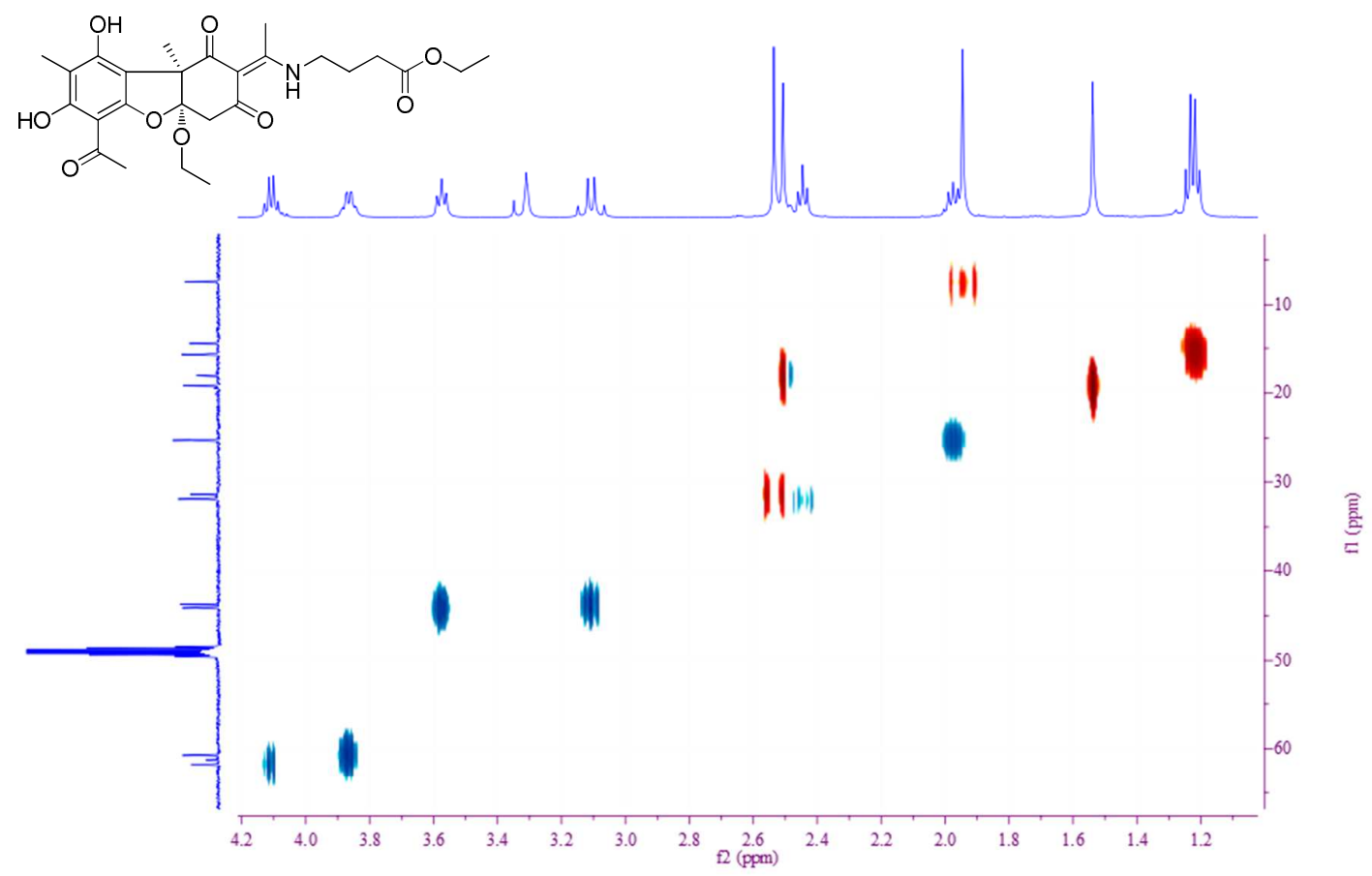

S44 gHSQC spectrum of compound 6 (Measured in $\mathrm{CD}_{3} \mathrm{OD}$ )

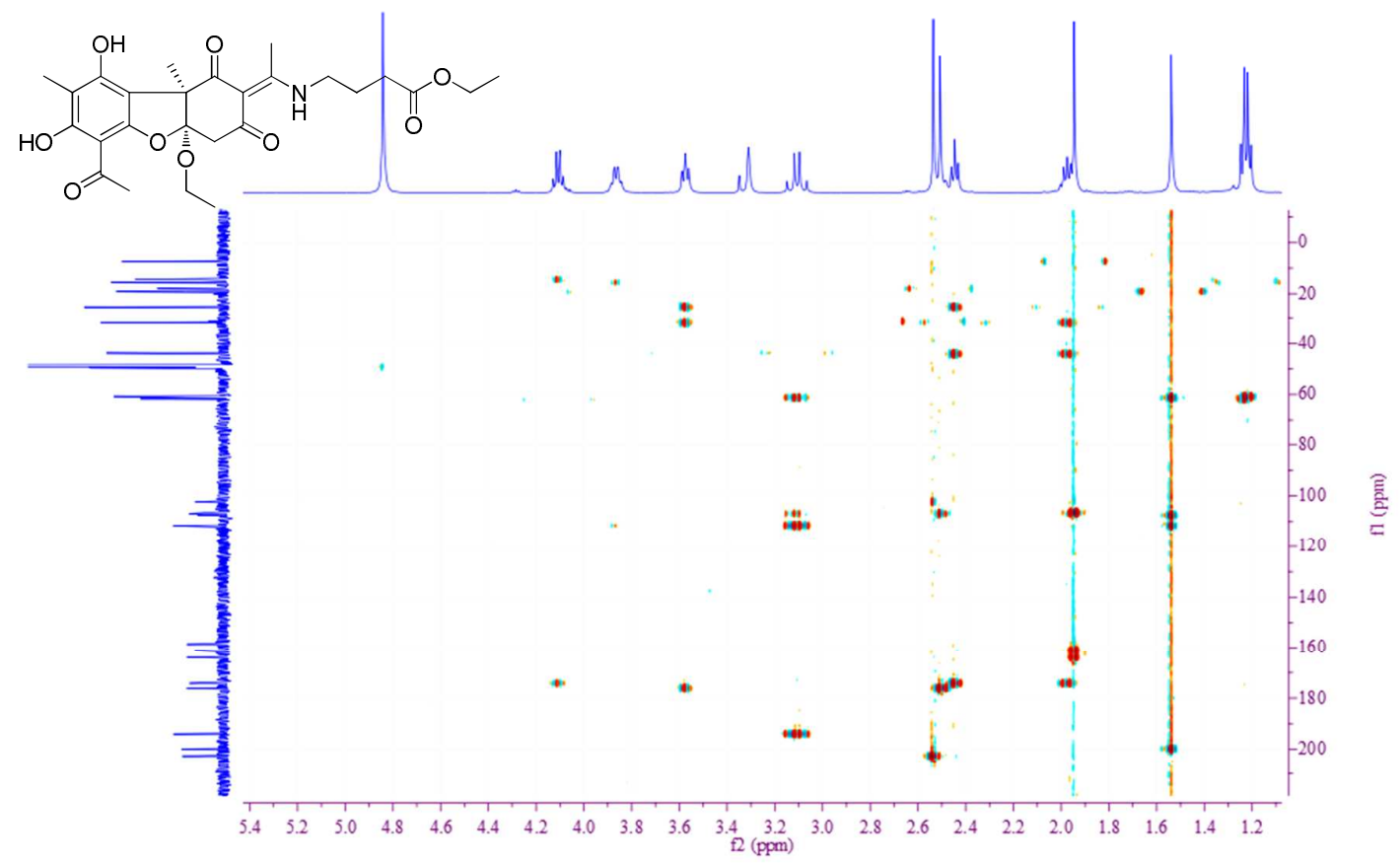

S45 gHMBC spectrum of compound 7 (Measured in $\mathrm{CD}_{3} \mathrm{OD}$ ) 


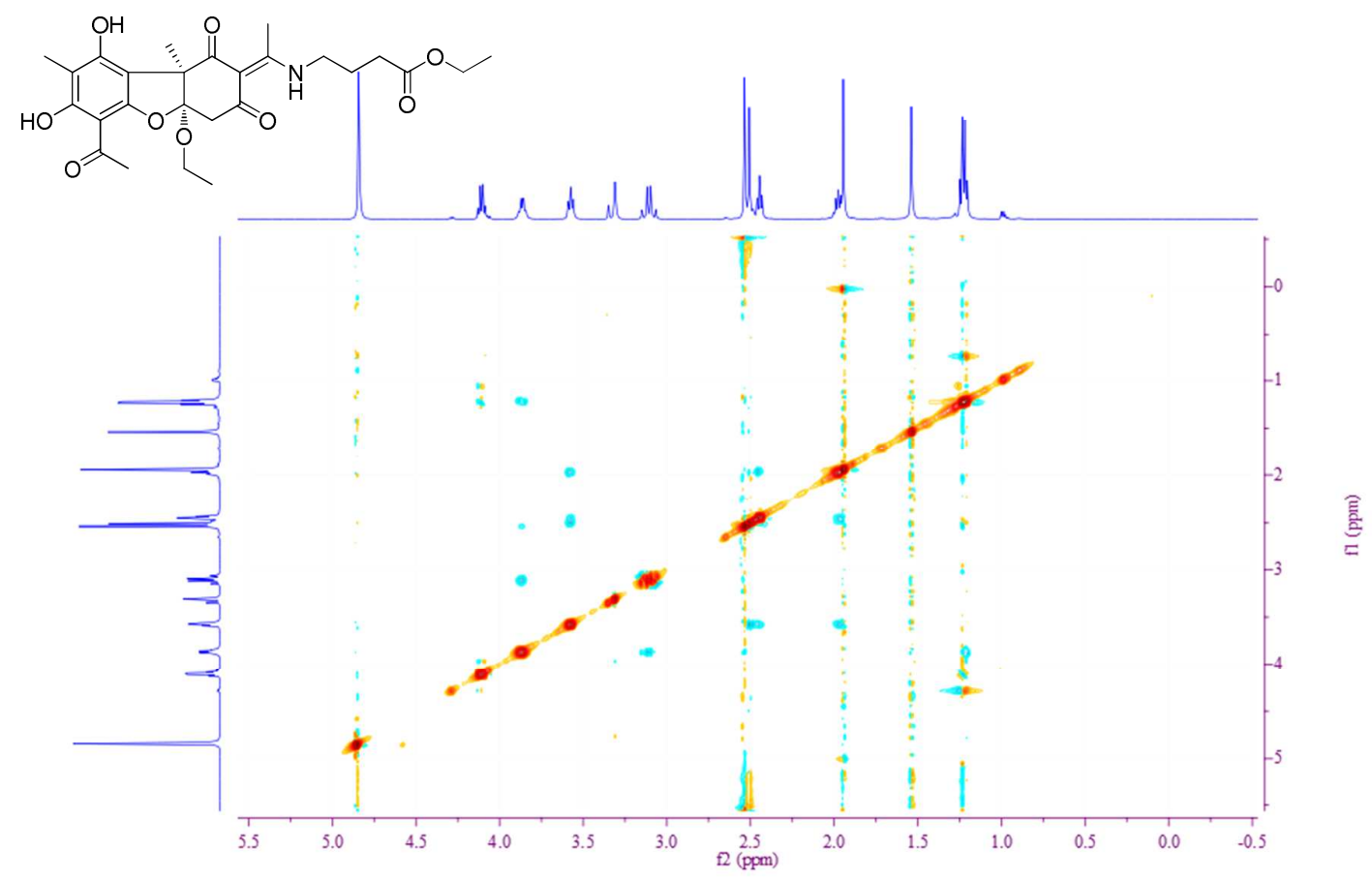

S46 NOESY spectrum of compound 6 (Measured in $\mathrm{CD}_{3} \mathrm{OD}$ )

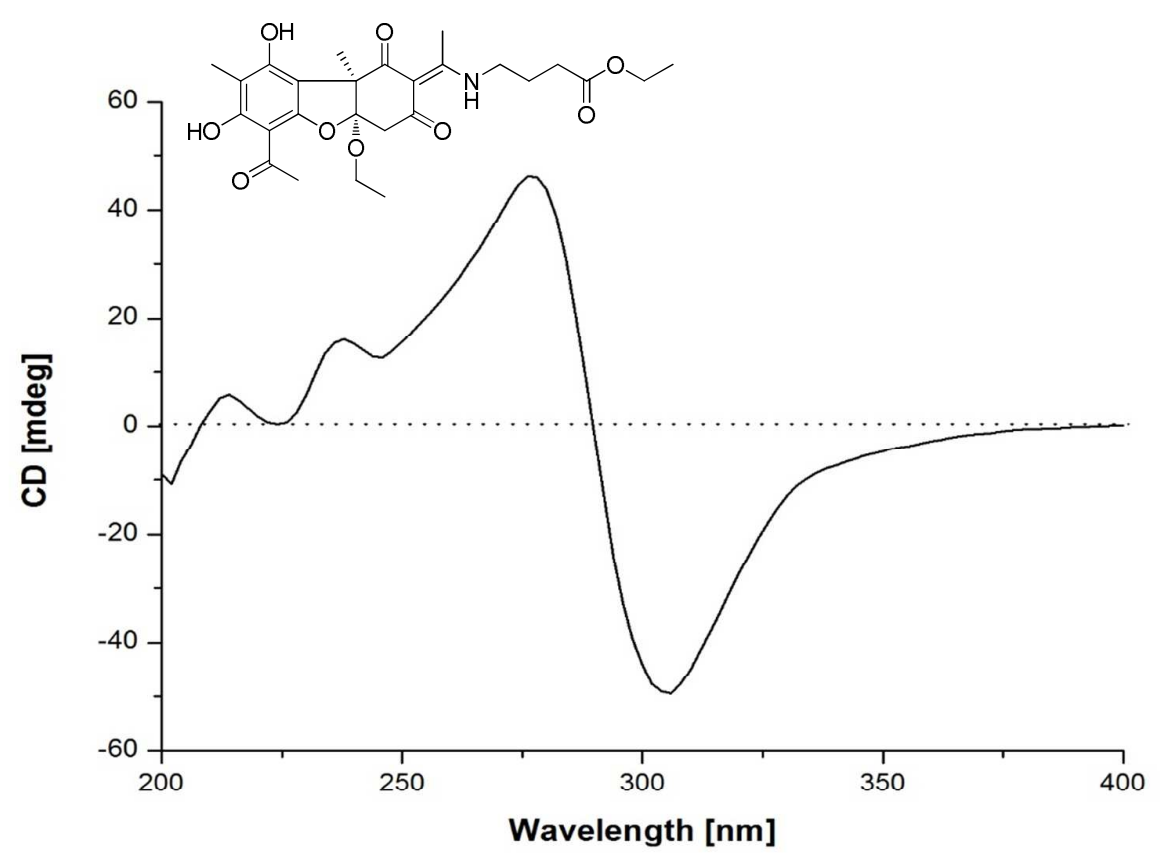

S47 CD spectrum of compound 6 (Measured in $\mathrm{CH}_{3} \mathrm{OH}$ ) 
Data File: D:IDatas|于学龙IU1435XB12_2 - 副本.Icd

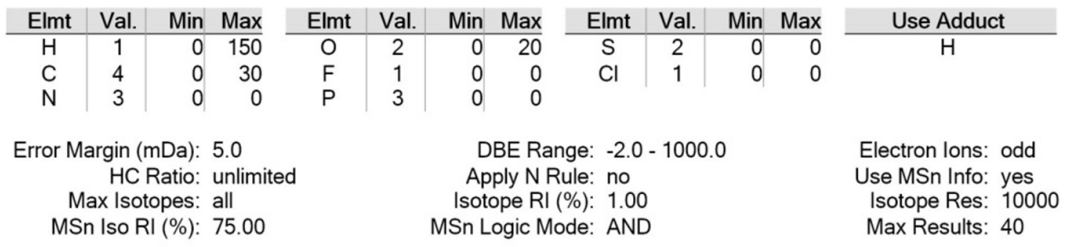

Event\#: $1 \mathrm{MS}(\mathrm{E}+)$ Ret. Time : 11.382 Scan\# : 2420

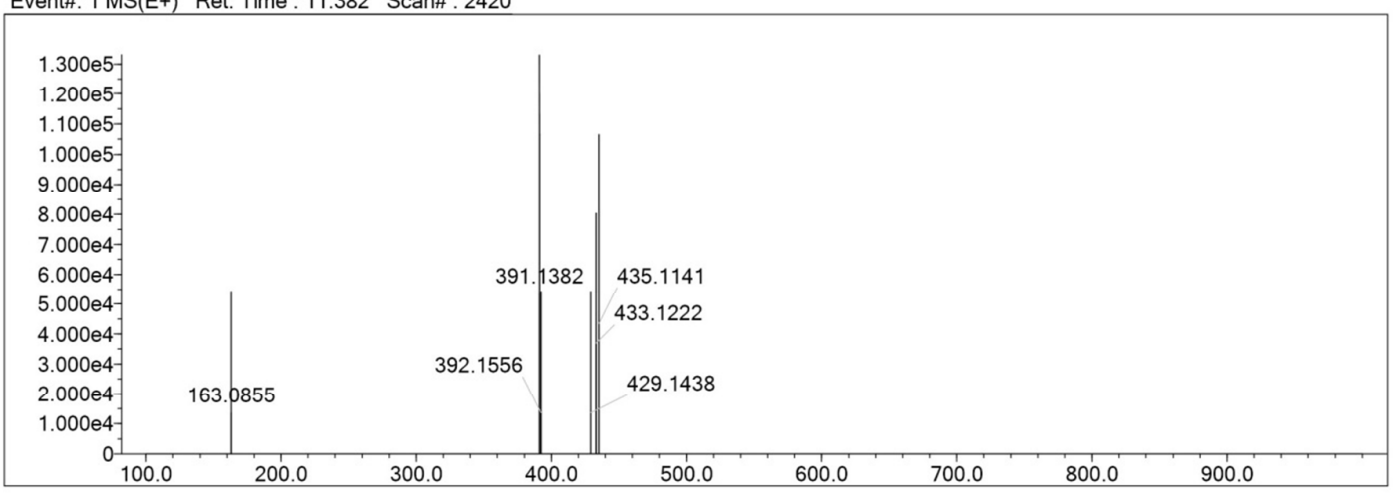

Measured region for $391.1382 \mathrm{~m} / \mathrm{z}$

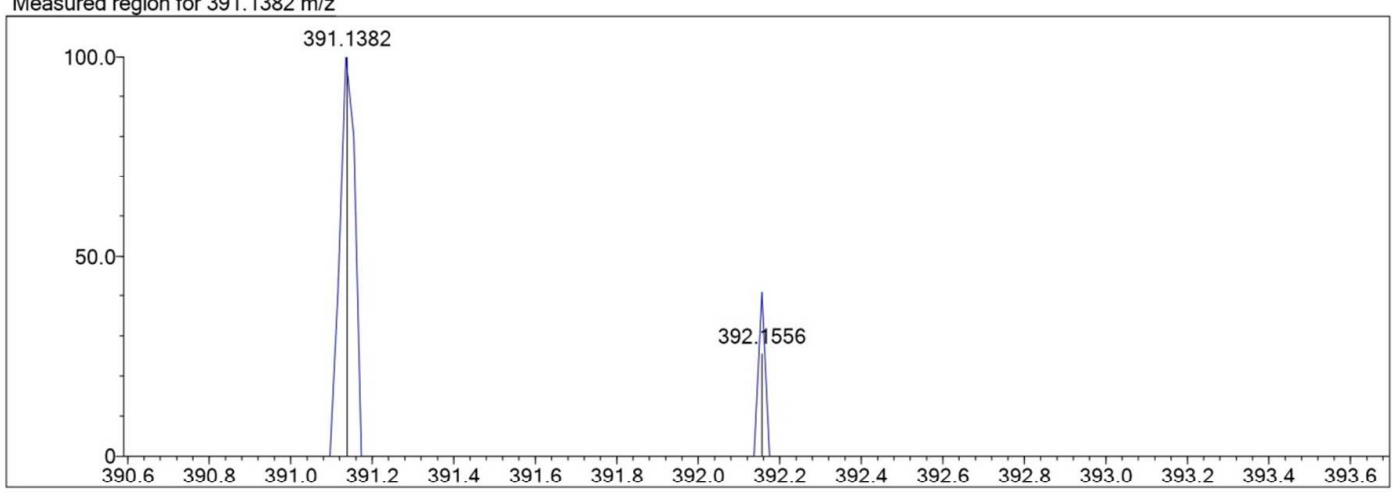

$\mathrm{C} 20 \mathrm{H} 22 \mathrm{O} 8[\mathrm{M}+\mathrm{H}]+$ : Predicted region for $391.1387 \mathrm{~m} / \mathrm{z}$

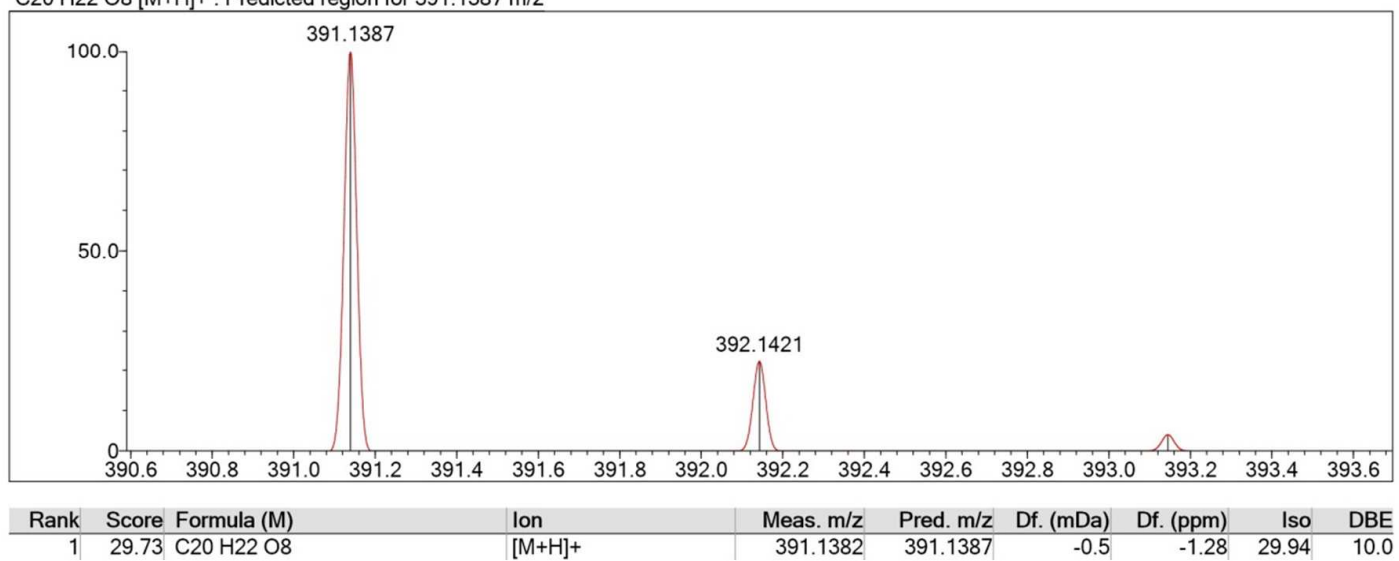

\section{S48 HRESIMS spectrum of compound 7}


<smiles>CCOC12CC(O)=C(C(C)=O)C(=O)[C@@]1(C)c1c(O)c(C)c(O)c(C(C)=O)c1O2</smiles>

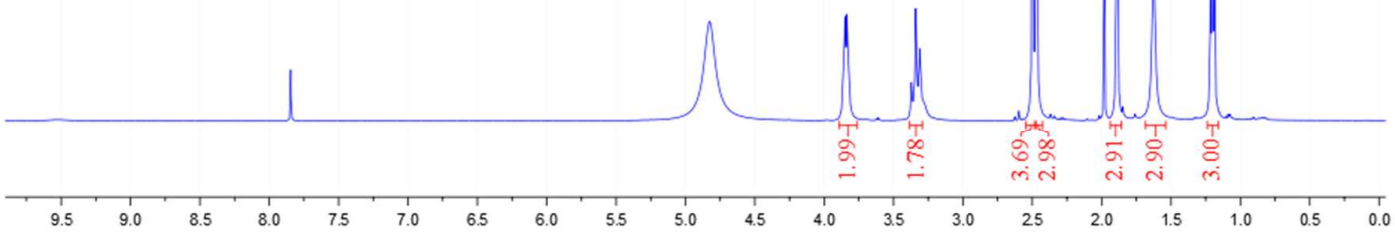

S49 ${ }^{1} \mathrm{H}$ NMR spectrum of compound 7 (Measured in $\mathrm{CD}_{3} \mathrm{OD}$ )
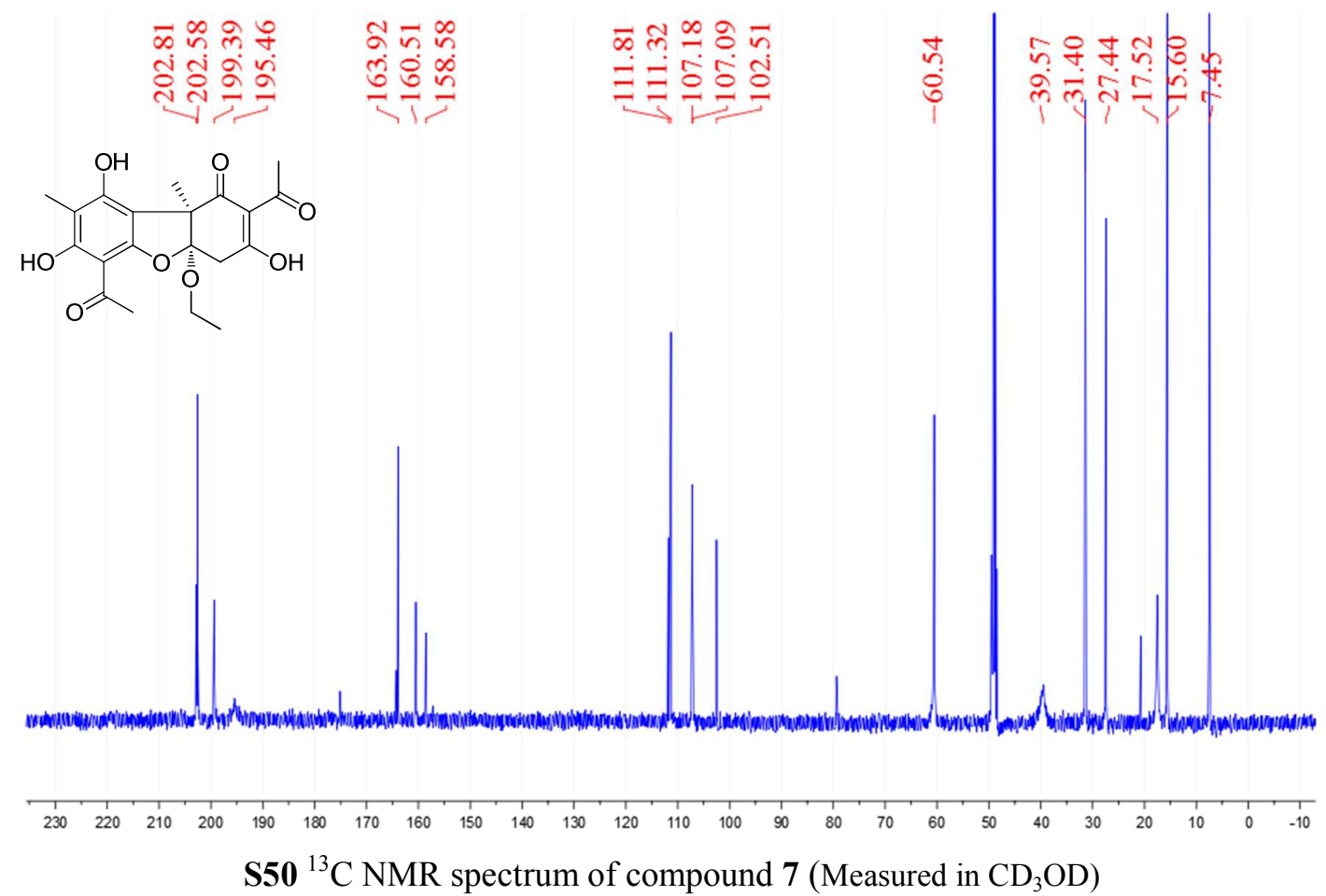


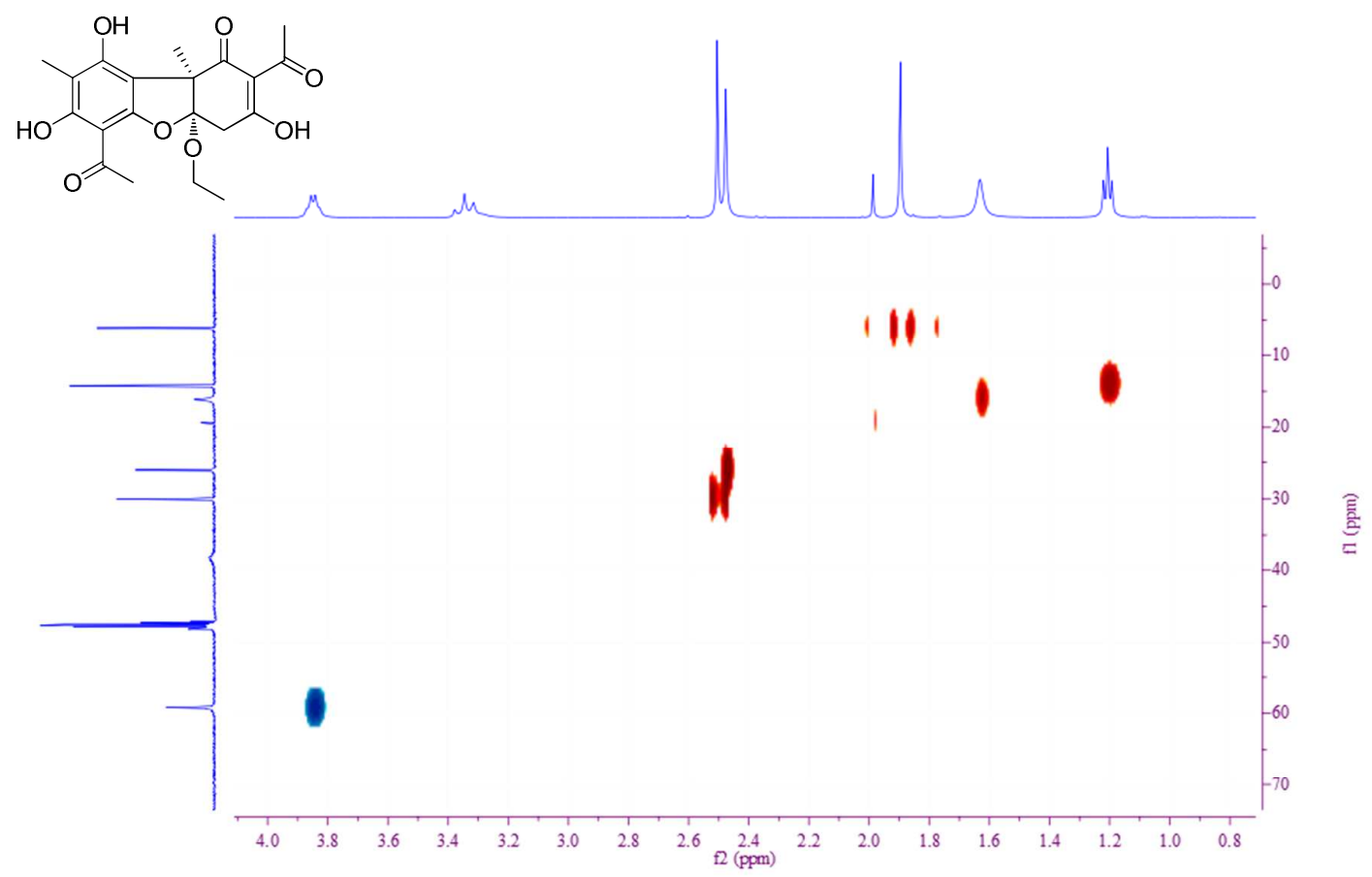

S51 gHSQC spectrum of compound 7 (Measured in $\mathrm{CD}_{3} \mathrm{OD}$ )

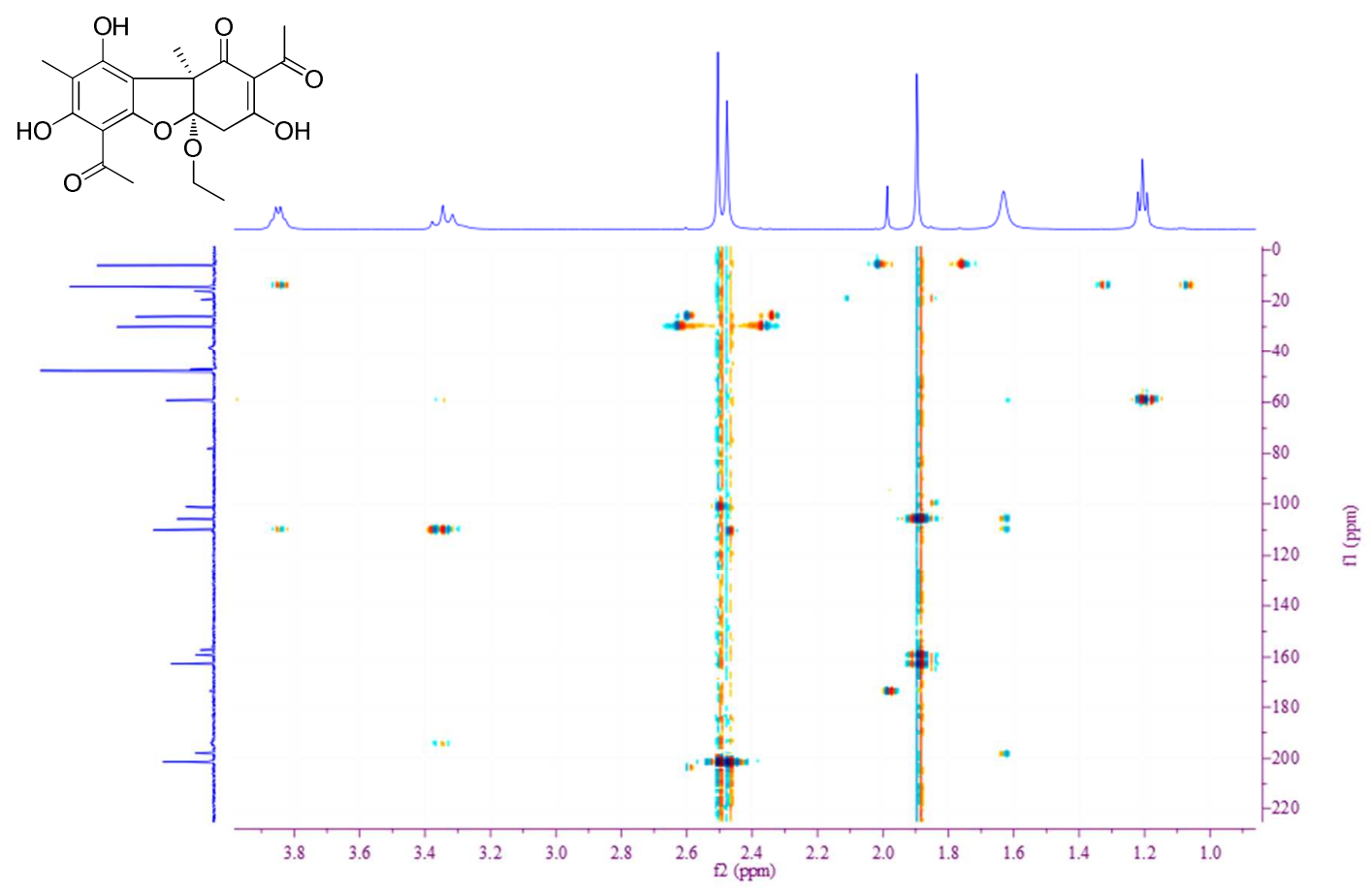

S52 gHMBC spectrum of compound 7 (Measured in $\mathrm{CD}_{3} \mathrm{OD}$ ) 


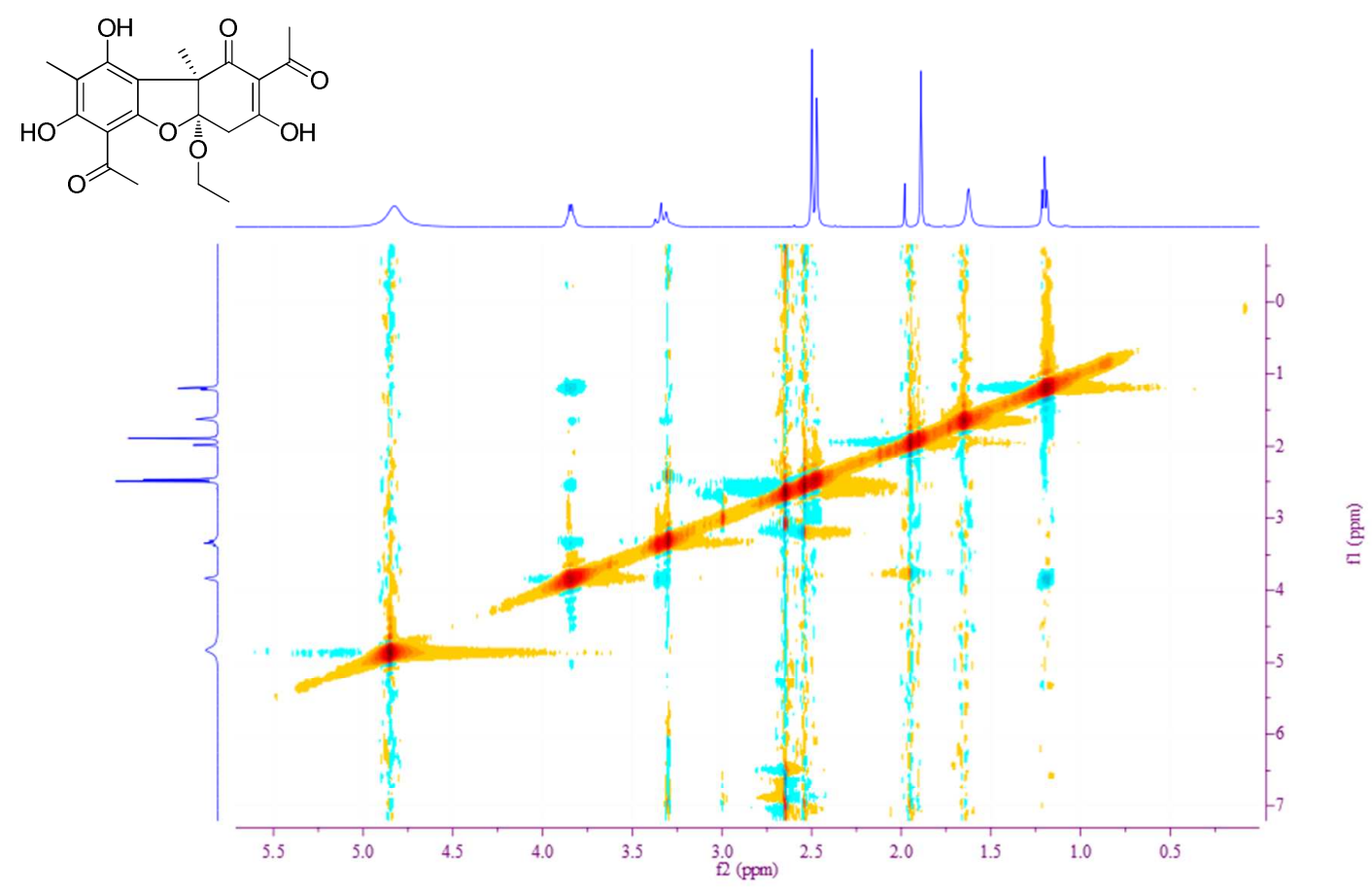

S53 NOESY spectrum of compound 7 (Measured in $\mathrm{CD}_{3} \mathrm{OD}$ )

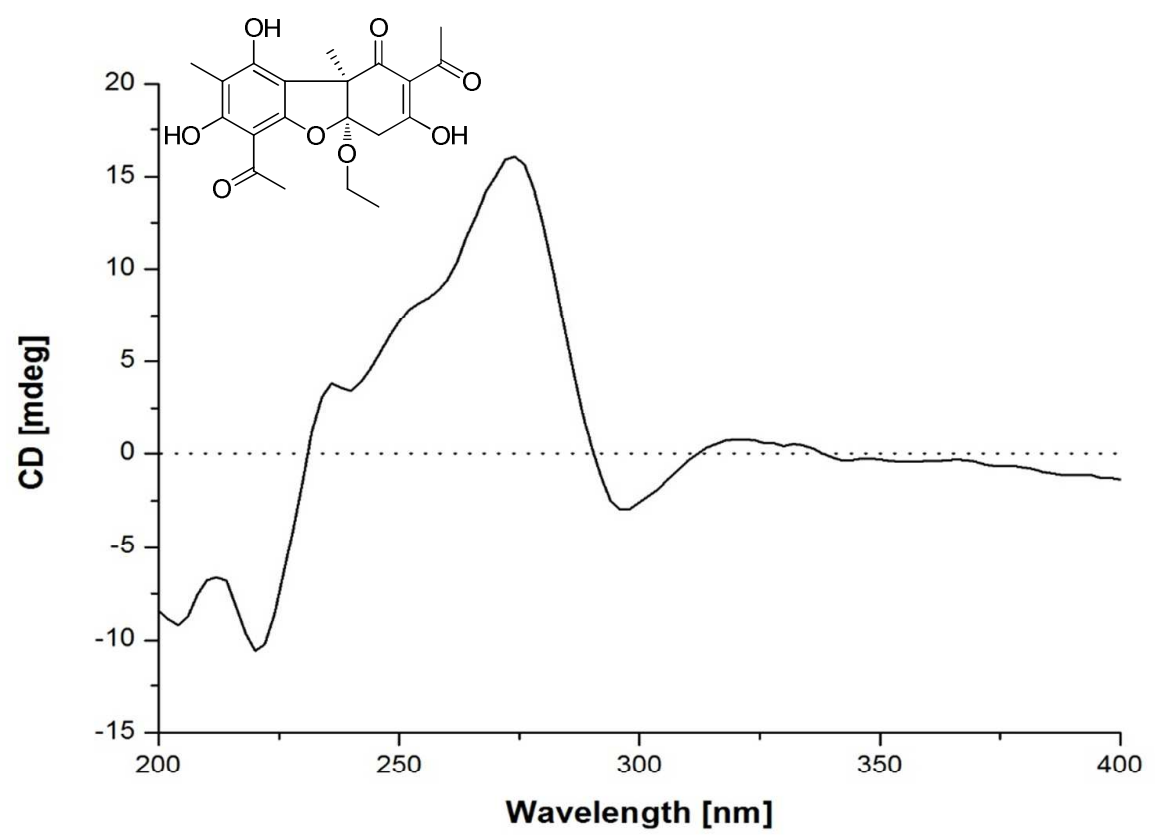

S54 CD spectrum of compound 7 (Measured in $\mathrm{CH}_{3} \mathrm{OH}$ ) 
Data File: D:IDatasI学生样品测试|20141118IU1435XB11_3.Icd

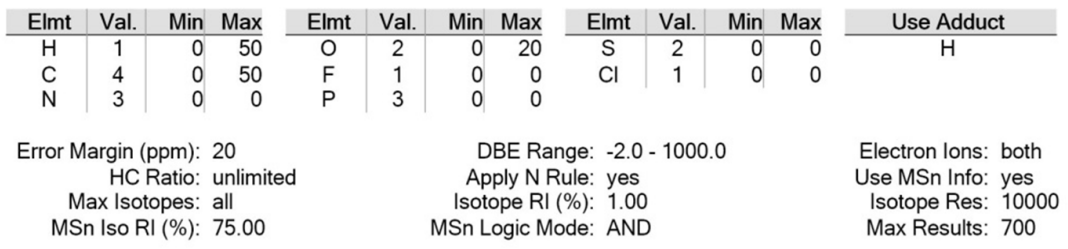

Event\#: 3 MS(E-) Ret. Time : 13.922 Scan\# : 3046

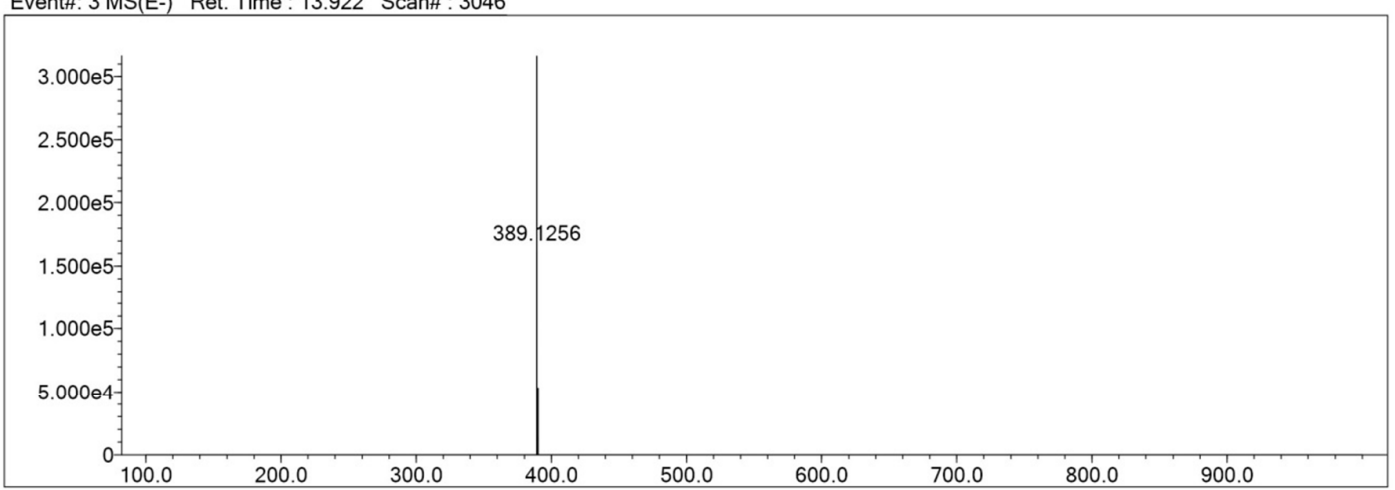

Measured region for $389.1256 \mathrm{~m} / \mathrm{z}$

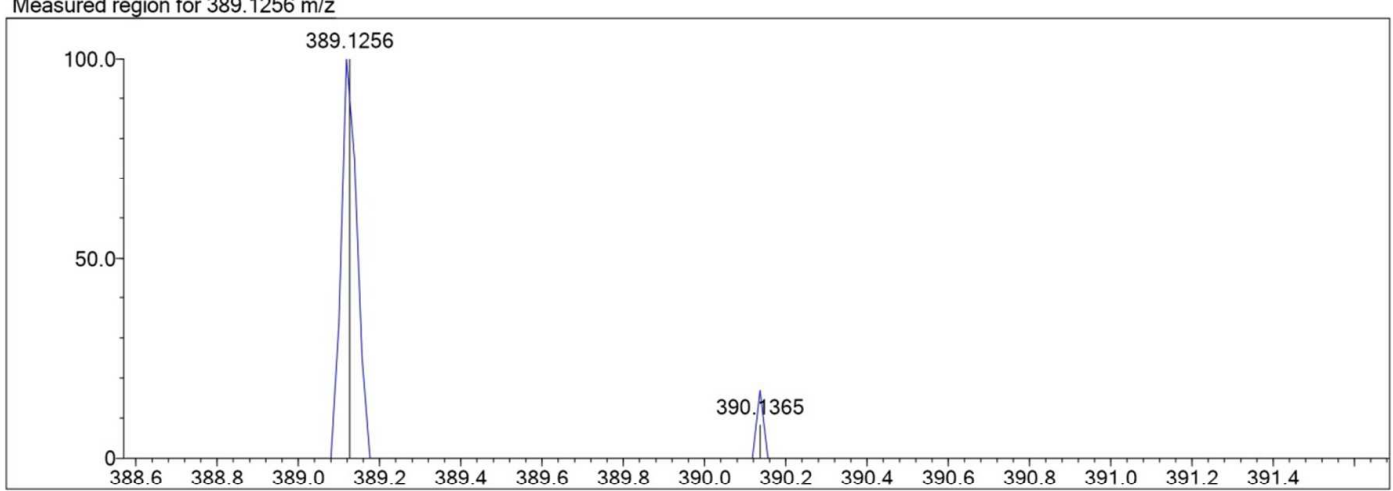

$\mathrm{C} 20 \mathrm{H} 22 \mathrm{O} 8$ [M-H]- : Predicted region for $389.1242 \mathrm{~m} / \mathrm{z}$

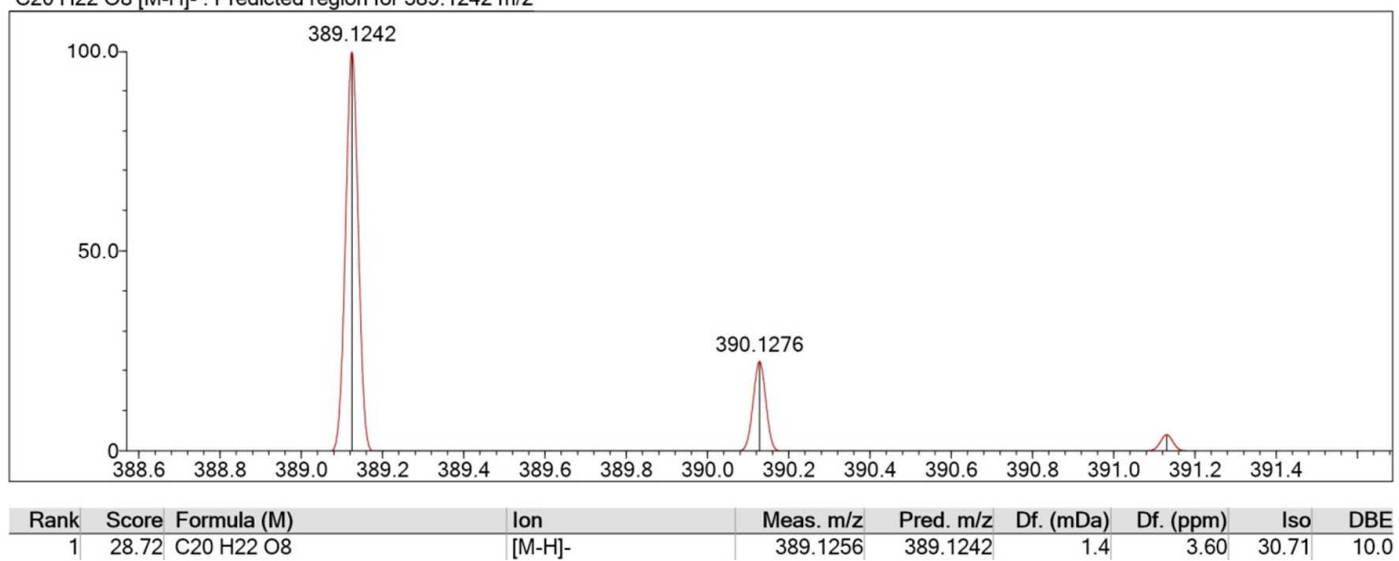

\section{S55 HRESIMS spectrum of compound 8}


<smiles>CCOC12CC(O)=C(C(C)=O)C(=O)[C@@]1(C)c1c(O)c(C(C)=O)c(O)c(C)c1O2</smiles><smiles>CCOC12CC(O)=C(C(C)=O)C(=O)[C@@]1(C)c1c(O)c(C(C)=O)c(O)c(C)c1O2</smiles>

\section{S56 ${ }^{1} \mathrm{H}$ NMR spectrum of compound 8 (Measured in $\mathrm{CD}_{3} \mathrm{OD}$ )}
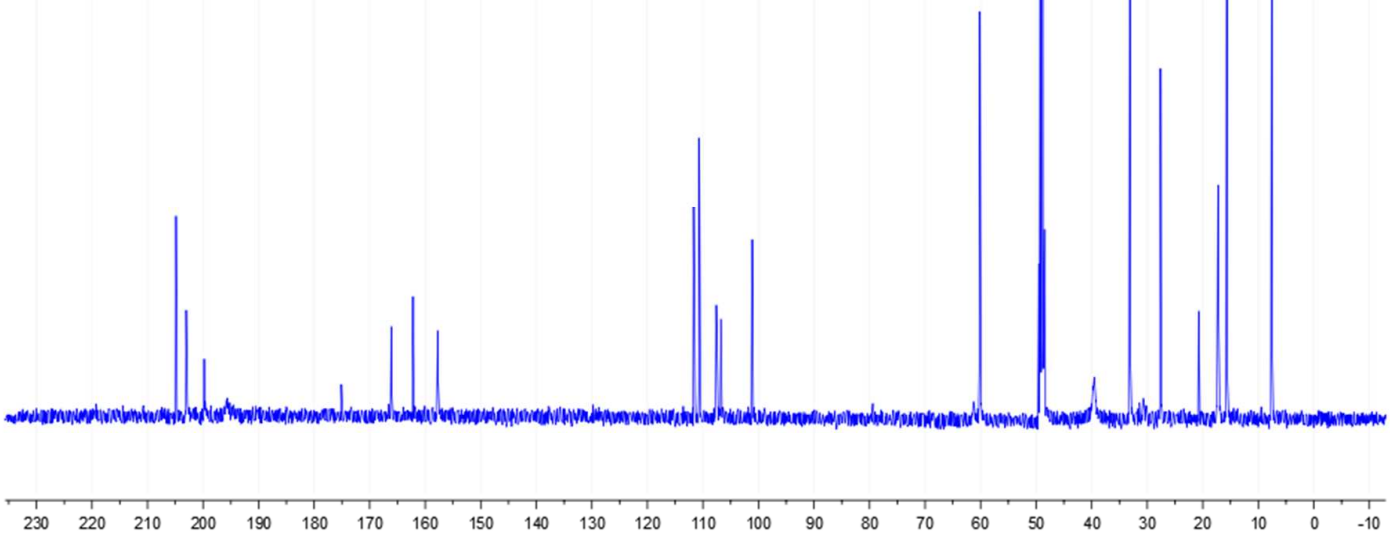

S57 ${ }^{13} \mathrm{C}$ NMR spectrum of compound 8 (Measured in $\mathrm{CD}_{3} \mathrm{OD}$ ) 


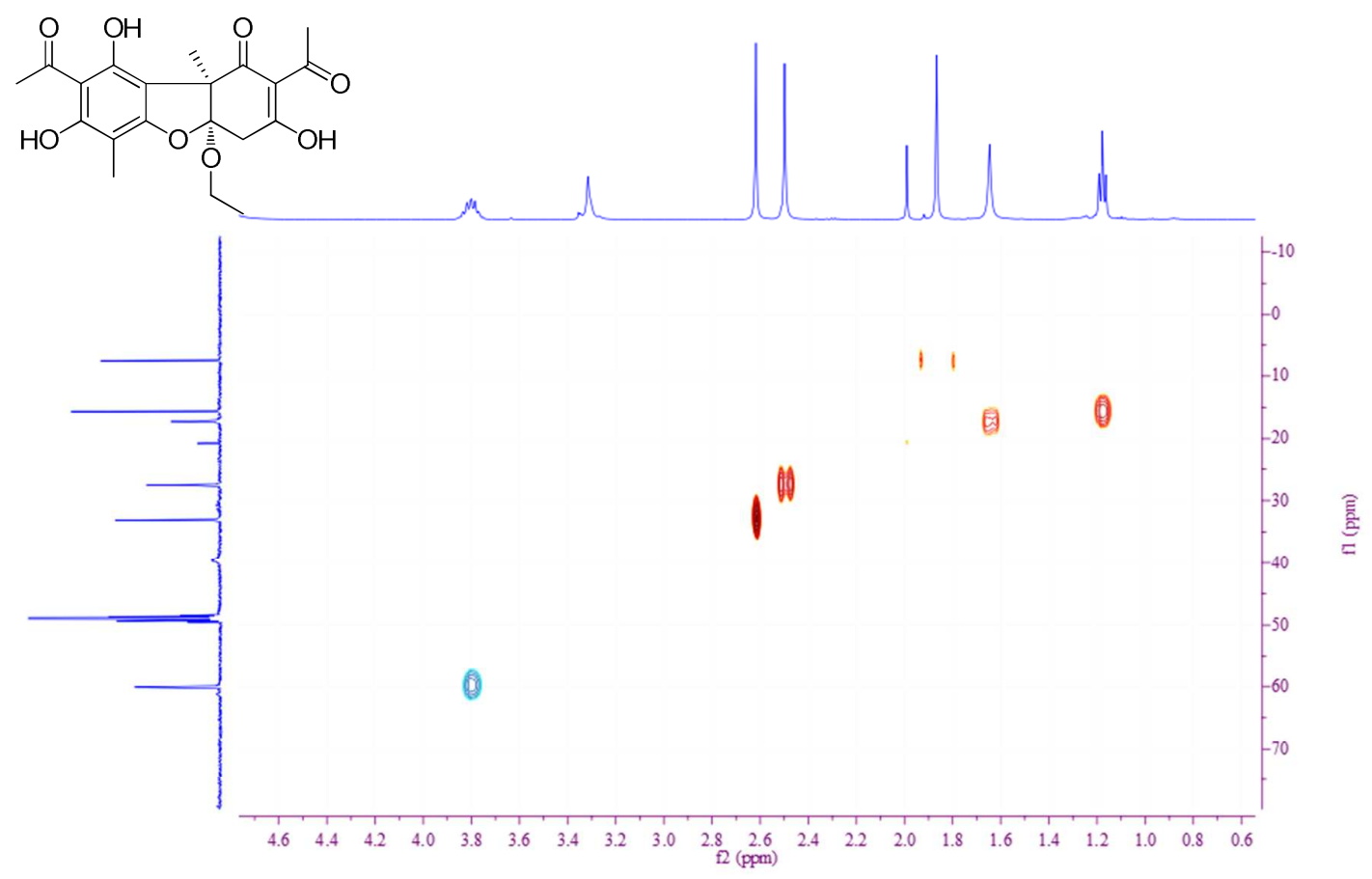

$\mathbf{S 5 8}$ gHSQC spectrum of compound $\mathbf{8}$ (Measured in $\mathrm{CD}_{3} \mathrm{OD}$ )

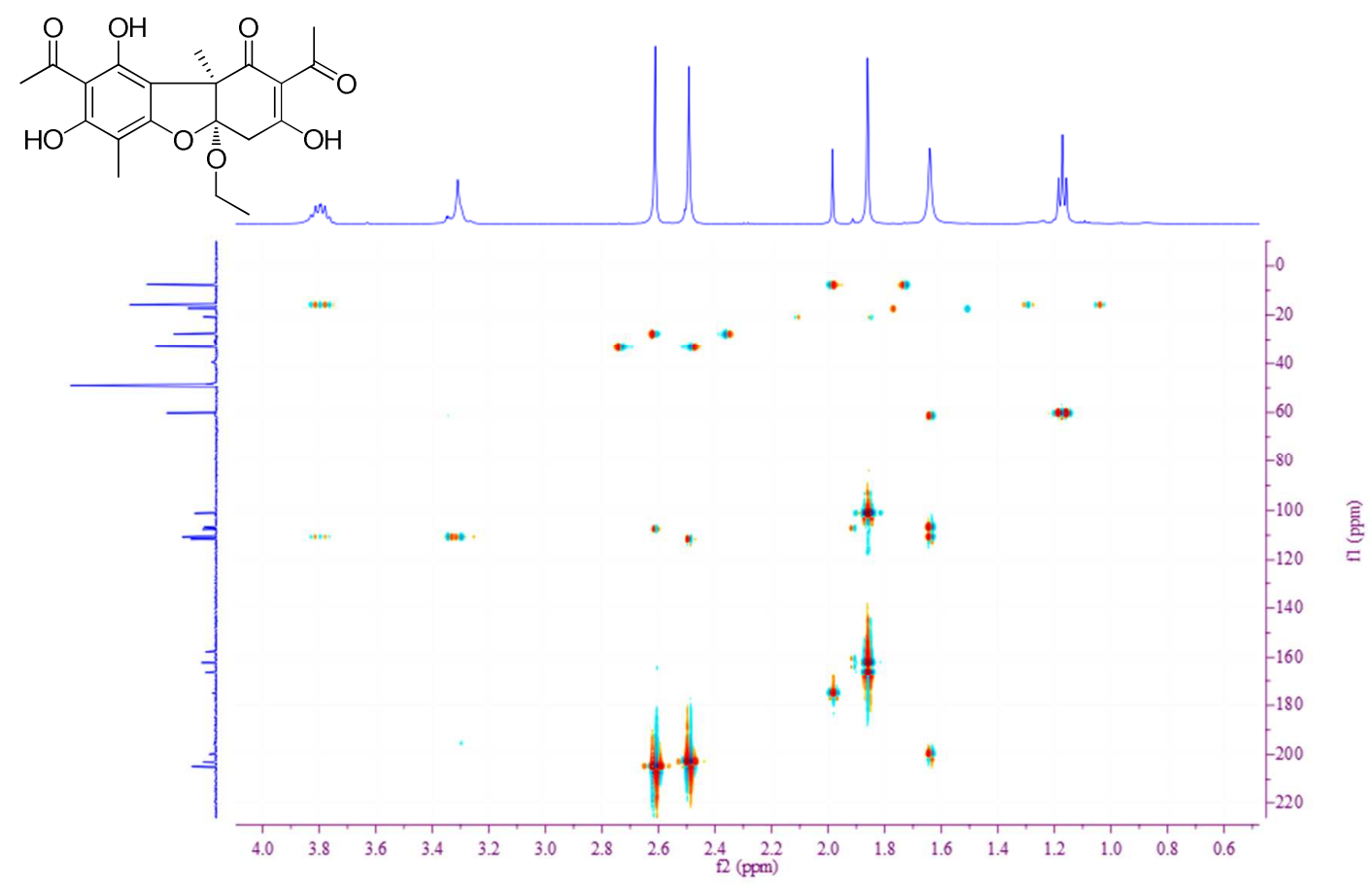

S59 gHMBC spectrum of compound 8 (Measured in $\mathrm{CD}_{3} \mathrm{OD}$ ) 


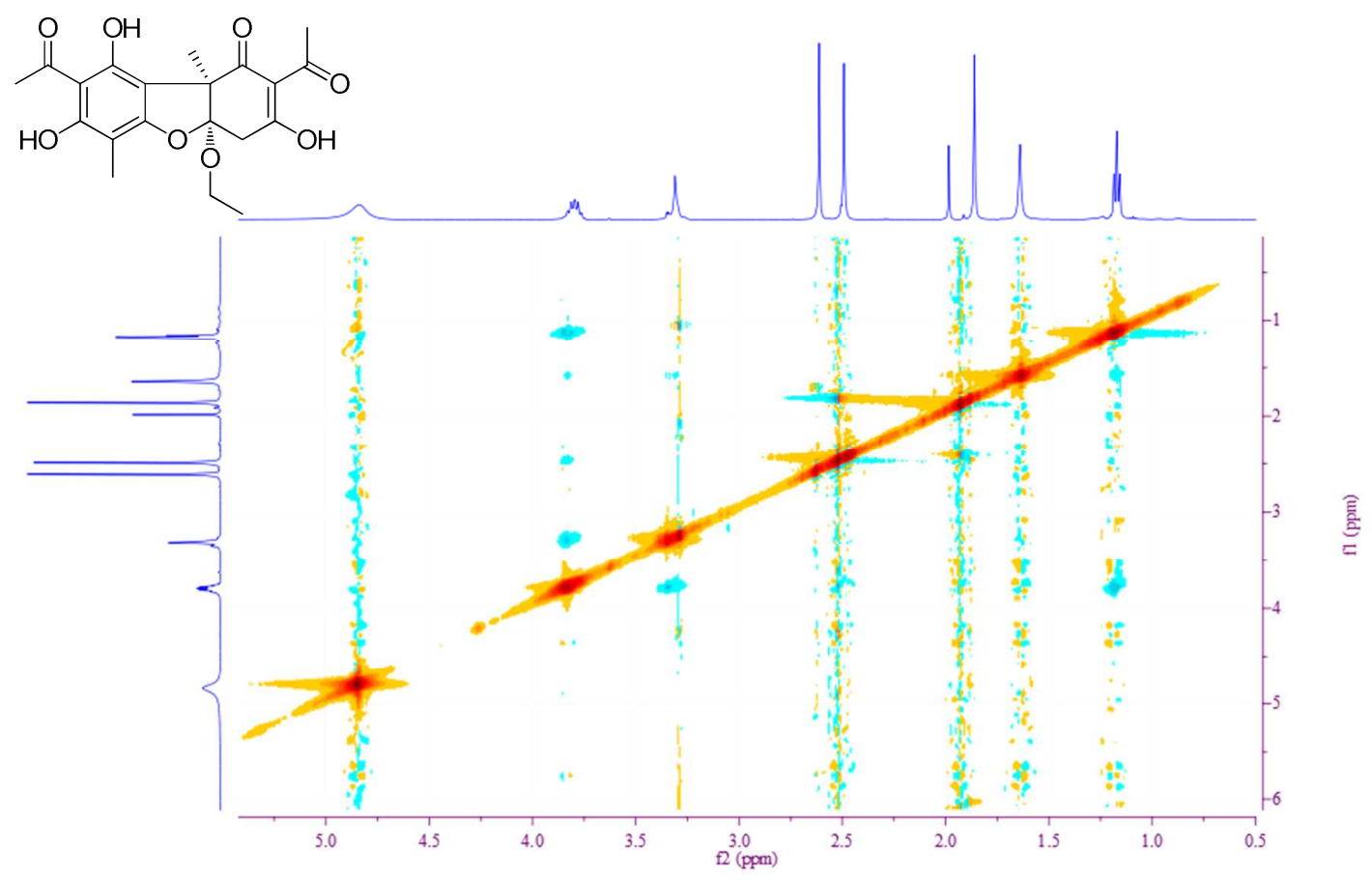

S60 NOESY spectrum of compound 8 (Measured in $\mathrm{CD}_{3} \mathrm{OD}$ )

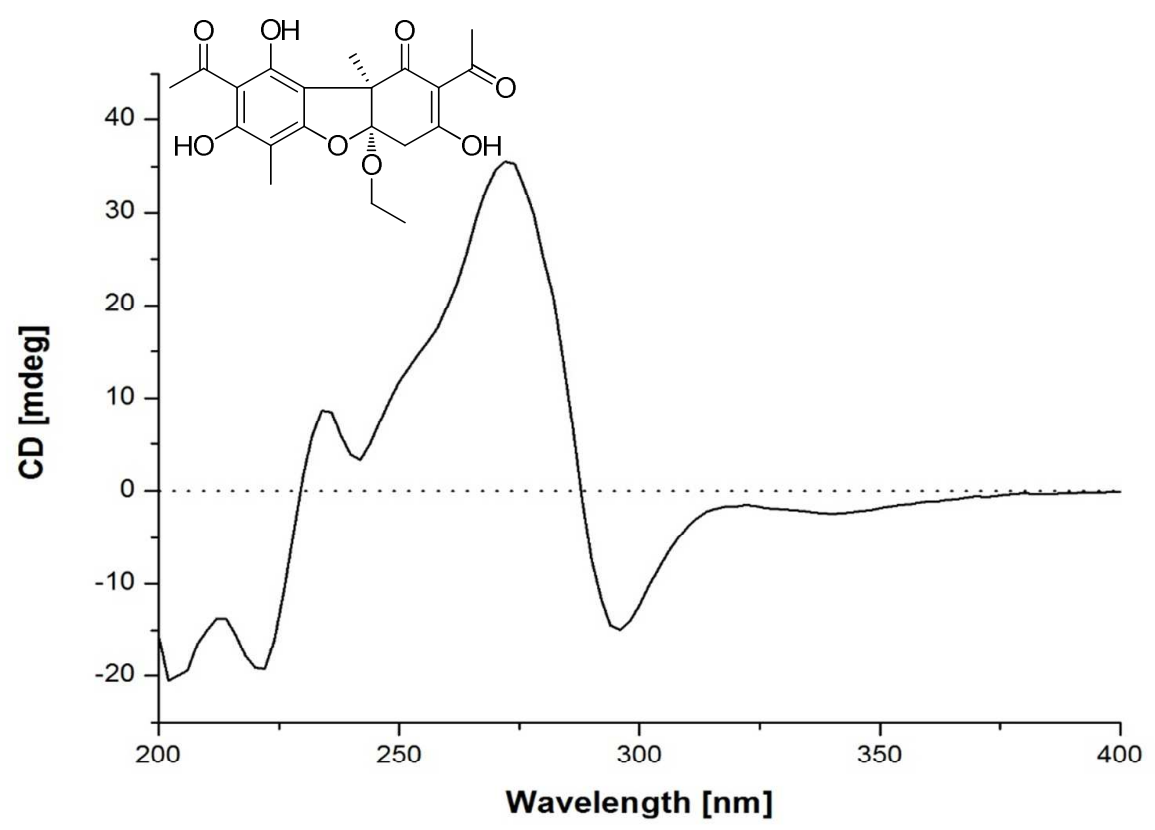

S61 CD spectrum of compound 8 (Measured in $\mathrm{CH}_{3} \mathrm{OH}$ ) 

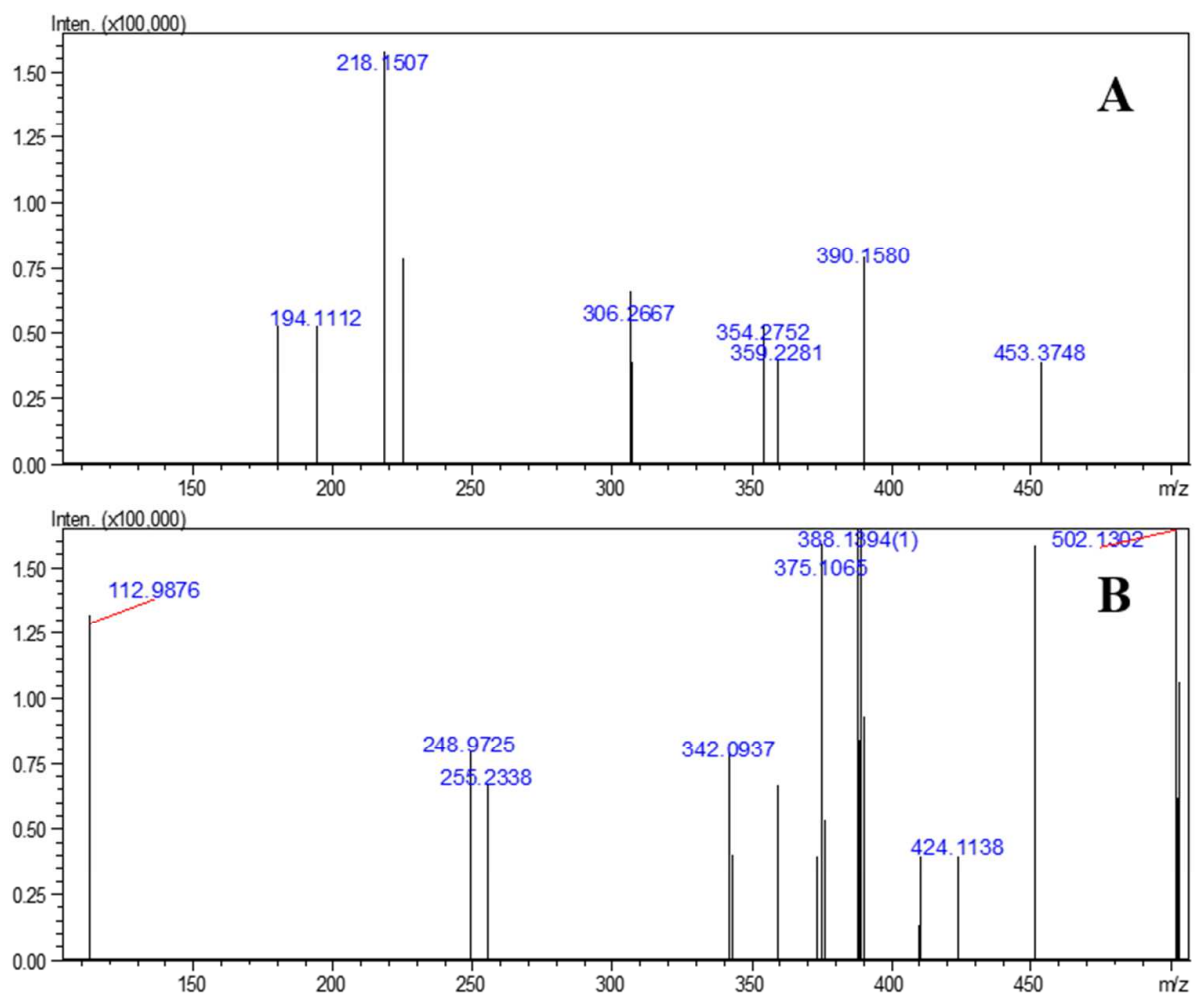

S62 LC-MS chromatograms in positive (A) and negative (B) modes of 2 in the MeOH extract of Usnea longissima

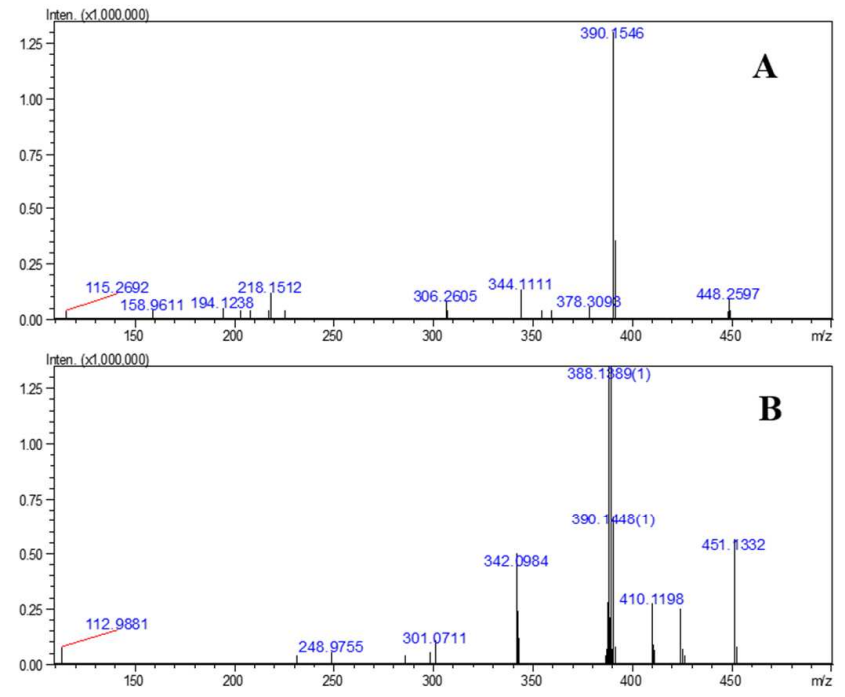

S63 LC-MS chromatograms in positive (A) and negative (B) modes of 2. 

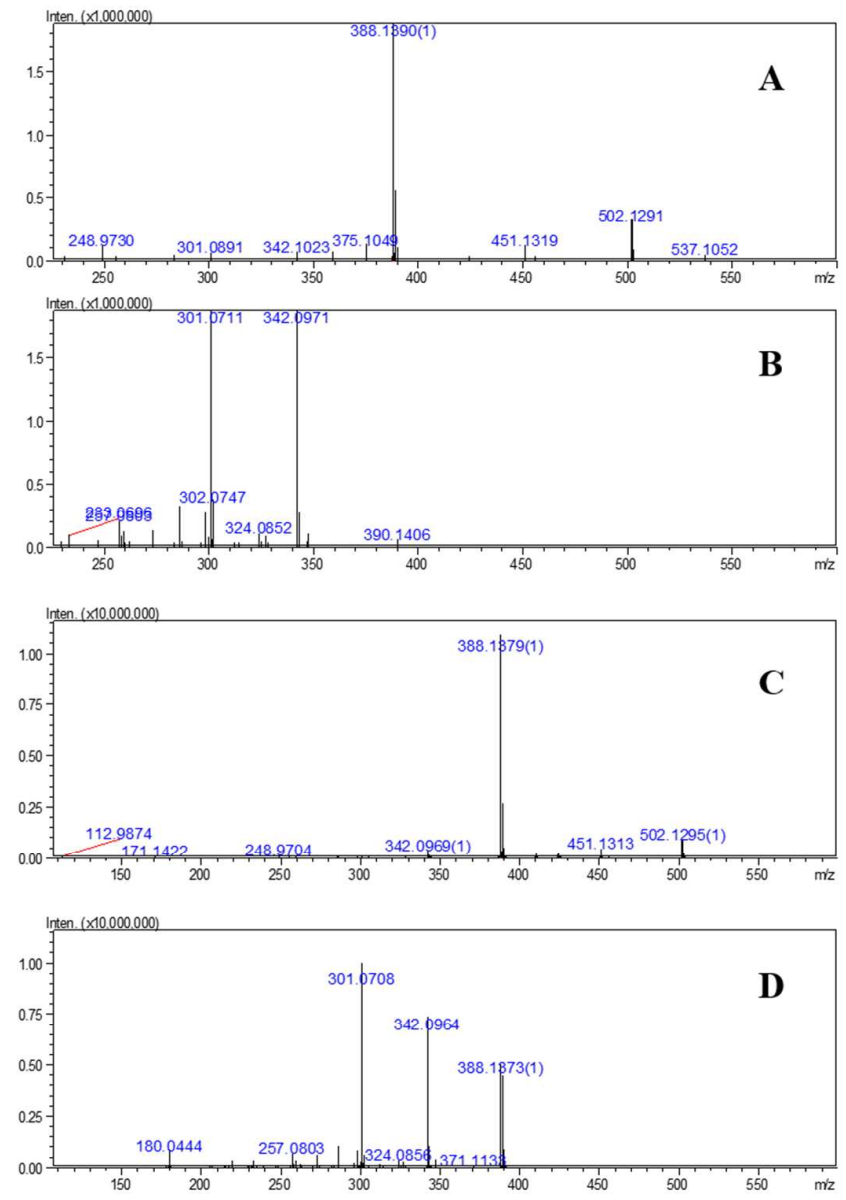

S64 Extract ion chromatograms in negative modes of $\mathbf{2}$ in $\mathrm{MeOH}$ extract of Usnea longissima (A) and its $\mathrm{MS}^{2}$ chromatogram (B); Extract ion chromatograms in negative modes of purified $\mathbf{2}(\mathbf{C})$ and its $\mathrm{MS}^{2}$ chromatogram (D). 